CENTRO UNIVERSITÁRIO FEI

MELISSA GALDINO DE SOUZA

CARACTERÍSTICAS EMPREENDEDORAS E O AMBIENTE ESCOLAR NA INTENÇÃO EMPREENDEDORA DE ALUNOS DO ENSINO MÉDIO/TÉCNICO 
MELISSA GALDINO DE SOUZA

\section{CARACTERÍSTICAS EMPREENDEDORAS E O AMBIENTE ESCOLAR NA INTENÇÃO EMPREENDEDORA DE ALUNOS DO ENSINO MÉDIO/TÉCNICO}

Dissertação de Mestrado apresentada ao Centro Universitário FEI, para obtenção do título de Mestre em Administração. Orientado pelo Prof. Dr. Edson Sadao Iizuka. 
centro

universitário

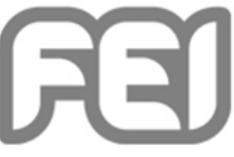

APRESENTAÇÃo DE DISSERTAÇÃo

ATA DA BANCA JULGADORA

Programa de Pós-Graduação Stricto Sensu em Administração

MESTRADO PPGA-10

Aluno: Melissa Galdino de Souza

Matrícula: 3117041

Título do Trabalho: Características empreendedoras e o ambiente escolar na intenção empreendedora de alunos do ensino médio/técnico

Área de Concentração: Gestão da Inovação

Orientador: Prof. Dr. Edson Sadao Iizuka

Data da realização da defesa: 17/06/2019.

\section{Avaliação da Banca Examinadora:}

São Paulo, 17 /06 /2019.

ORIGINAL ASSINADA

\section{MEMBROS DA BANCA EXAMINADORA}

Prof. Dr. Edson Sadao Iizuka

Ass. :

Prof. Dr. Edmilson Alves de Moraes Ass.:

Prof. Dr. Gustavo H. S. M. de Moraes Ass.:

A Banca Julgadora acima-assinada atribuiu ao aluno o seguinte resultado:

$$
\text { APROVADO }
$$

REPROVADO

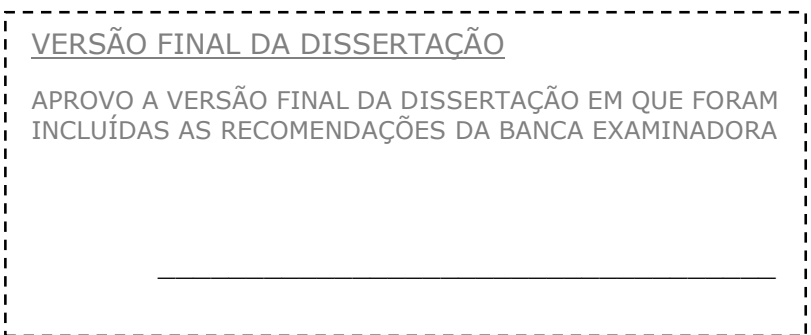

Aprovação do Coordenador do Programa de Pós-graduação 


\section{AGRADECIMENTOS}

Gostaria de agradecer a todos que contribuíram para realização desse trabalho.

Aos meus amigos que o Mestrado me proporcionou, em especial ao "Canto Direito".

Aos meus amigos e colegas professores das Etecs que ajudaram na realização da pesquisa e pelas palavras de encorajamento.

A minha família, sempre paciente em entender minha ausência e o quanto essa jornada foi importante para mim.

Ao corpo docente do Programa de Pós-Graduação em Administração da FEI, pelo aprendizado proporcionado ao longo de todas as aulas e pela amizade.

Aos professores, em especial ao professor Edson Sadao Iizuka em acreditar em mim e ter a paciência em me "lapidar" e ensinar a não ser somente uma pesquisadora ou profissional melhor, mas principalmente em ser uma pessoa melhor (ainda não terminou...). Ao coorientador Gustavo Hermínio Salati Marcondes de Moraes por me ajudar, estar à disposição e confiar na pesquisa. E ao professor Edmilson Alves de Moraes em me auxiliar sempre que possível e, vendo em mim um potencial que muitas vezes nem eu mesma enxergava.

O presente trabalho foi realizado com apoio da Coordenação de Aperfeiçoamento de Pessoal de Nível Superior - Brasil (CAPES) - Código de Financiamento 001. 
A alegria não chega apenas no encontro do achado, mas faz parte do processo da busca. E ensinar e aprender não pode dar-se fora da procura, fora da boniteza e da alegria. 


\section{RESUMO}

Essa pesquisa trata das características empreendedoras e o ambiente escolar na intenção empreendedora de alunos do ensino médio/técnico. Os alunos das Etecs Lauro Gomes e Juscelino Kubitschek de Oliveira foram selecionados para essa pesquisa. A investigação parte do seguinte questionamento: em que medida as características empreendedoras e o ambiente escolar podem influenciar na intenção empreendedora dos alunos do ensino médio/técnico das Etecs? Para responder tal pergunta, adotou-se o método quantitativo e utilizou-se a técnica de Mínimos Quadrados Parciais (PLS-SEM). A amostra utilizada foi composta por 384 estudantes de cursos técnicos, tais como Administração, Desenvolvimento de Sistemas, Química, Secretariado, entre outros. O modelo proposto, inicialmente aplicado no ensino superior, foi validado e se mostrou adequado aos alunos do ensino médio/técnico. As hipóteses confirmadas evidenciaram que a autoeficácia é influenciada positivamente pelas características empreendedoras; a intenção empreendedora influenciada positivamente pela autoeficácia e pelo ambiente escolar. Na análise de multigrupos houve confirmação em relação a existência de diferença entre o relacionamento da liderança e autoeficácia e sociabilidade e autoeficácia no que diz respeito ao curso. Os resultados da pesquisa contribuem no avanço do conhecimento acerca do interesse pela atividade empreendedora dos estudantes do ensino médio/técnico, algo incipiente na literatura nacional e internacional.

Palavras - chave: Intenção empreendedor. Características empreendedoras. Ambiente escolar. Ensino médio/técnico. Etecs. 


\begin{abstract}
This research deals with the entrepreneurial characteristics and the school environment in the entrepreneurial intention of high school/technical students. The students of the Etecs Lauro Gomes and Juscelino Kubitschek de Oliveira were selected for this research. Research is part of the following question: to what extent are entrepreneurial characteristics and the school environment influenced by the entrepreneurial intent of high school/technical students of the Etecs? To answer this question, the quantitative method was adopted and the Partial Least Squares (PLS-SEM) was used technique. The sample used consisted of 384 students of technical courses, such as Administration, Systems Development, Chemistry, Secretariat, among others. The proposed model, initially applied in higher education, was validated and proved appropriate for high school/technical students. The confirmed hypotheses showed that self-efficacy is positively influenced by the entrepreneurial characteristics; the entrepreneurial intent positively influenced by the self-efficacy and the school environment. In the analysis of Multigroups there was confirmation regarding the existence of difference between the relationship of leadership and self-efficacy and sociability and self-efficacy in relation to the course. The results of the research contribute to the advancement of knowledge about the interest in the entrepreneurial activity of high school/technical students, something incipient in the national and international literature.
\end{abstract}

Keywords: Entrepreneurial intent. Entrepreneurial characteristics. School environment. High school/technical. Etecs. 


\section{LISTA DE GRÁFICOS}

Gráfico 1 - Quantidade de Cursos por Eixos Tecnológicos ..................................................29

Gráfico 2 - Alunos por Eixo Tecnológico ……................................................................ 30

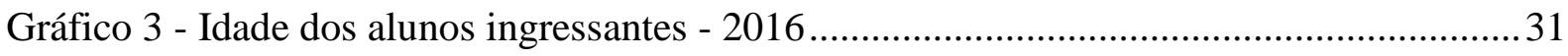

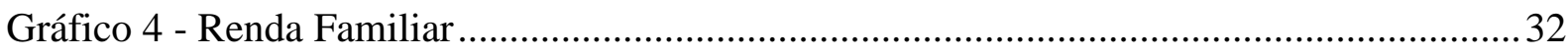

Gráfico 5 - Quantidade de alunos - Técnico em Administração ............................................. 34

Gráfico 6 - Relação de cursos com e sem disciplinas de Empreendedorismo ..........................37

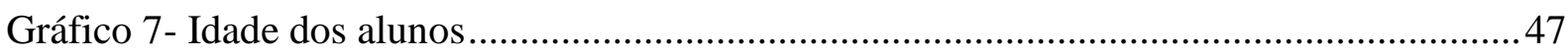




\section{LISTA DE QUADROS}

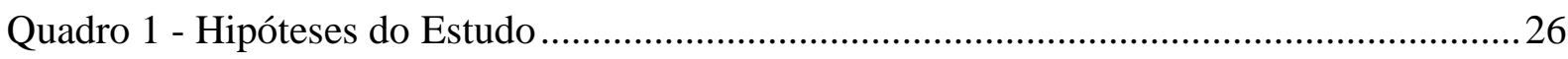

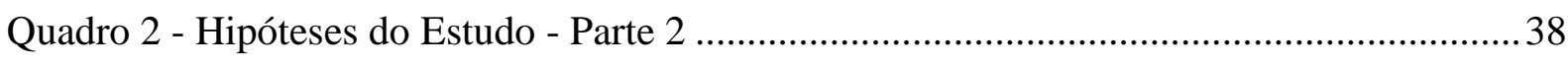

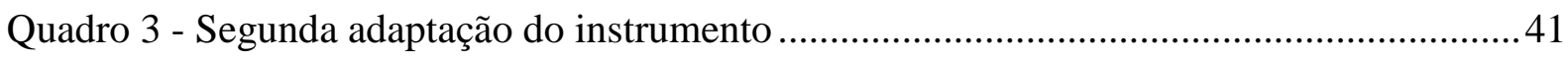

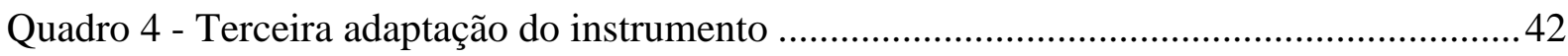

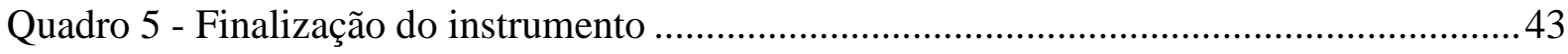

Quadro 6 - Resultado do Teste de Hipóteses................................................................................54 


\section{LISTA DE TABELAS}

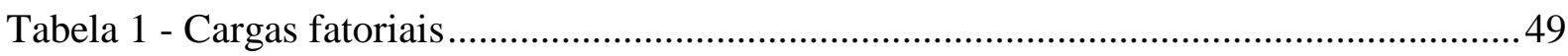

Tabela 2 - Variância Média Extraída........................................................................................50

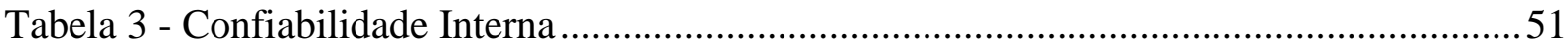

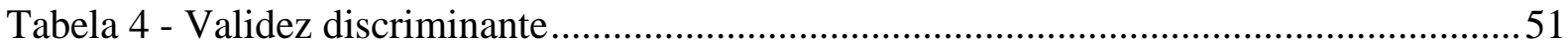

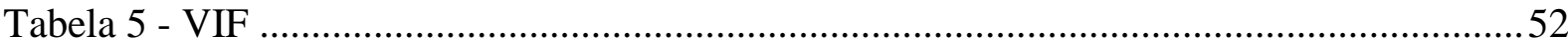

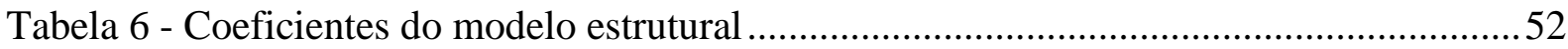

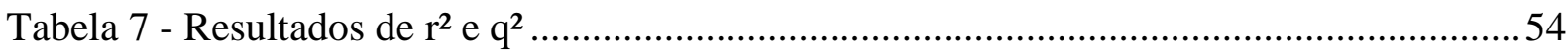

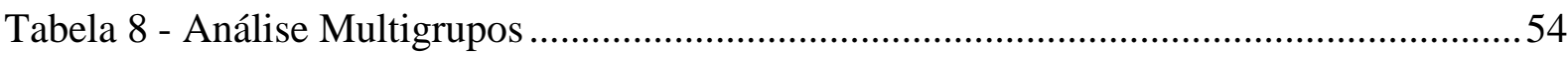


1 INTRODUÇÃO ................................................................................................................................11

2 O ENSINO E A APRENDIZAGEM DO EMPREENDEDORISMO ...............................14

2.1 O ENSINO E A APRENDIZAGEM DO EMPREENDEDORISMO NO NÍVEL MÉDIO 18

2.2 O ENSINO E A APRENDIZAGEM MEDIDOS PELAS CARACTERÍSTICAS

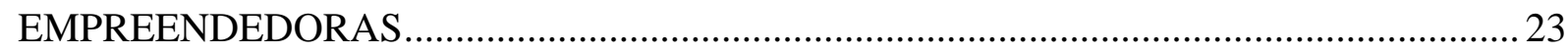

3 AMBIENTE ESCOLAR .........................................................................................................27

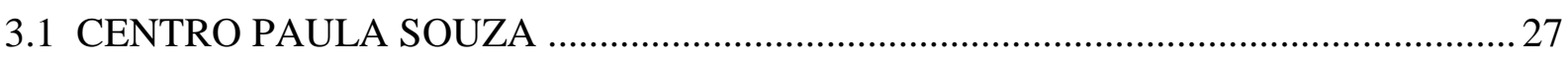

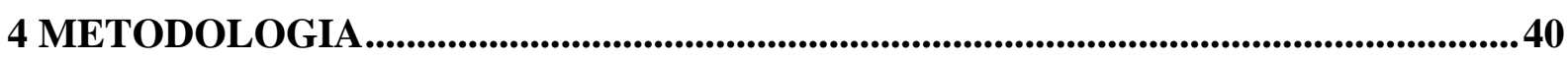

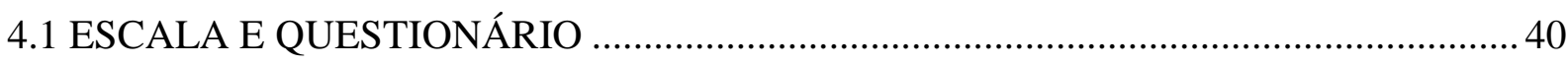

4.1.1 Primeira etapa: alteração da linguagem do questionário..............................................40

4.1.2 Segunda etapa: mudanças no construto de autoeficácia e ambiente..........................41

4.1.3 Terceira etapa: sugestão da pesquisadora no construto de autoeficácia.....................42

4.1.4 Quarta etapa: entrevista com professores especialistas e pré-teste............................43

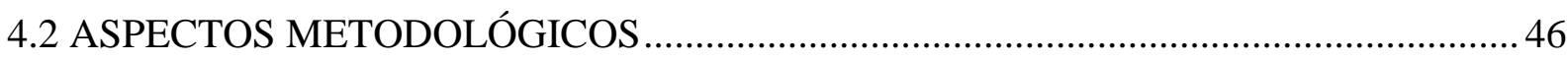

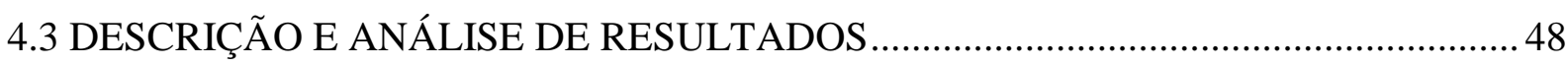

4.3.1 Análise dos construtos reflexivos .........................................................................................48

4.4 AVALIAÇÃO DO MODELO ESTRUTURAL ………………………..................... 51

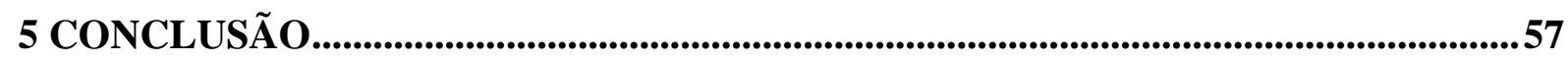

REFERÊNCIAS ..............................................................................................................59

APÊNDICE A - Eixos Tecnológicos do Centro Paula Souza .. Erro! Indicador não definido.

APÊNDICE B - Questionário .....................................................................................72

APÊNDICE C - A Educação Profissional no Brasil .............................................................77

ANEXO A - Mapa das Etecs..........................................................................................................84 


\section{INTRODUÇÃO}

Para realizar essa pesquisa sobre as características empreendedoras e o ambiente escolar na intenção empreendedora de alunos do ensino médio/técnico, serão estudadas 2 escolas técnicas estaduais (Etecs): Lauro Gomes e Juscelino Kubitschek de Oliveira, do Centro Paula Souza (CPS), uma autarquia do governo do Estado de São Paulo composta por Etecs e Faculdades de Tecnologia (Fatecs) criada em 1969 com objetivo de "promover a educação pública profissional e tecnológica dentro de referenciais de excelência, visando o desenvolvimento tecnológico, econômico e social do Estado de São Paulo" (SOUZA, 2015).

O início do CPS se deu a partir da necessidade de oferecer mão de obra qualificada para os diversos setores produtivos, essa concepção não mudou ao longo dos anos, em uma pesquisa constatou-se que cerca de $77 \%$ dos técnicos formados em 2016 estão trabalhando até um ano após sua formação (SOUZA, 2017a, 2017b).

É visto que no decorrer do tempo, sua trajetória vai se moldando e acompanhando a evolução do mercado de trabalho e o ensino do empreendedorismo torna-se um dos objetivos estratégicos da instituição (SOUZA, 2015, 2017a). Por meio de feiras, eventos, projetos, ações, convênios e parcerias, o CPS introduz a cultura do empreendedorismo em sua instituição. A partir dessas práticas que serão detalhadas ao longo dessa pesquisa, é possível identificar a preocupação pelo fomento do empreendedorismo.

A escolha de instituições dessa rede de ensino para esse estudo, também está ligada à sua dimensão e ao seu reconhecimento, pois ao longo dos anos conseguiu ser a maior rede estadual de educação profissional gratuita da América Latina e hoje é considerada referência nacional na área de formação técnica, não só pelo seu tamanho - com mais de 223 unidades -, como também pela qualidade dos seus 140 cursos oferecidos (ARAÚJO; DEMAI; PRATA, 2017; SOUZA, 2015, 2017a).

Um fator que também foi levado em consideração é a qualidade no ensino, tomando como base o Exame Nacional do Ensino Médio (ENEM), este indicador classifica as escolas técnicas estaduais (Etecs) entre as melhores escolas públicas do estado de São Paulo. Outro critério utilizado é a pesquisa realizada internamente pela instituição chamada de WebSAI, um sistema de avaliação institucional que permite analisar por meio do seu funcionamento, resultados e impactos na realidade social em que a instituição é inserida, sob o ponto de vista do corpo discente e docente. Com esses dados a instituição consegue mensurar o seu impacto em um contexto social e profissional na vida dos estudantes e levanta dados importantes quanto ao seu desempenho administrativo e pedagógico (SOUZA, 2015, 2017a; UEMURA, 2016). 
Até o momento outros autores analisaram o CPS levando em conta outras questões como as práticas pedagógicas e as metodologias ativas e quanto isso afeta a percepção dos alunos em relação ao ensino e à aprendizagem (LECHUGO, 2016; SOUZA, 2016); os fatores determinantes para o bom desempenho das Etecs (UEMURA, 2016); em como o ensino da instituição contribui para o aprendizado de competências na trajetória profissional de seus egressos (AGUIAR, 2013); e, como o papel da gestão impacta em todas essas práticas (RUIZ, 2014), mas nenhum trouxe a temática apresentada nesta dissertação.

Diante desse quadro encontra-se a oportunidade para pesquisar sobre os efeitos das características empreendedoras e o ambiente escolar na intenção empreendedora de alunos do ensino médio/técnico utilizando as Etecs como objeto de estudo.

Considera-se, além disso, que a temática do ensino e da aprendizagem do empreendedorismo no ensino médio, podem ocorrer por meio de diversas ações, sob a ótica do ensino, pesquisa e extensão, mediante tais abordagens o aluno tem contato experiencial com o empreendedorismo, por meio de práticas pedagógicas realizadas em sala de aula (ILANDER, 2010; KURATKO, 2005), como também, atividades desenvolvidas fora do ambiente escolar (GIOVANELA et al., 2012; ILANDER, 2010; LAUTENSCHLÄGER; HAASE, 2011), e a partir de uma disciplina fixa no currículo do curso (RUSKOVAARA et al., 2010).

O CPS tenta estimular o ensino do empreendedorismo realizando iniciativas que vão desde a criação de uma Etec voltada exclusivamente para o empreendedorismo (ETEC Sebrae), à geração de órgãos e departamentos (Agência INOVA PAULA SOUZA) dentro da instituição para que a cultura do empreendedorismo seja disseminada, a partir de ações tanto para os professores mediante formação, quanto para os alunos por meio de eventos (SOUZA, 2015).

De acordo com a literatura acadêmica nacional e internacional sobre o ensino e a aprendizagem empreendedora, é possível identificar estudos que relatam sistemas de educação pelo mundo aplicando o ensino do empreendedorismo no nível médio, e analisando a intenção empreendedora dos alunos (COMMISSION, 2006; ELERT; ANDERSSON; WENNBERG, 2015; LEPOUTRE et al., 2010; MARQUES et al., 2012). Ao tratar sobre esse assunto é possível encontrar duas correntes, os autores Bonnett e Furnham (1991) e Hickie (2011) afirmam que o adolescente que tem contato com o empreendedorismo na sua formação em nível médio pensa em tornar-se dono do próprio negócio, já Paço et al. (2011b) argumentam que esse contato do empreendedorismo no ensino médio auxilia o jovem no desenvolvimento de características específicas e habilidades que lhe serão úteis quando adultos, independentemente, se o mesmo seguirá na carreira de empreendedor ou não. 
Foram localizadas três pesquisas dentro da produção acadêmica brasileira sobre o tema, tendo como foco no ensino médio. A primeira delas com objetivo de investigar uma melhor compreensão quanto as competências que compõem a Educação Empreendedora, contudo esta pesquisa aborda os 3 níveis de ensino: fundamental, médio e superior (PEREIRA, 2018). A próxima pesquisa elabora uma proposta para inserção de uma disciplina de empreendedorismo em uma instituição de ensino nível médio (MAYER, 2001; ZAMBON, 2014). E, finalmente, a terceira utilizou-se o mesmo objeto de pesquisa (CPS) e realizou uma análise parecida com a que este trabalho se propõe a realizar, verificando se existem características empreendedoras no ensino médio/técnico, no entanto a análise se restringiu à alunos egressos (PEREIRA, 2018).

No Brasil, existem projetos paralelos à educação formal que auxiliam no ensino do empreendedorismo, como por exemplo, o projeto Fazendo Acontecer do Instituto Fazendo Acontecer do Prof. Dr. José Dornelas (INSTITUTO FAZENDO ACONTECER, 2018), e o outro projeto é do Serviço Brasileiro de Apoio às Micro e Pequenas Empresas (SEBRAE), cuja iniciativa intitulada como Educação Empreendedora tem como objetivo difundir a educação ao empreendedorismo nas instituições de ensino de todos os níveis de escolaridade (SEBRAE SERVIÇO BRASILEIRO DE APOIO ÁS MICROS E PEQUENAS EMPRESAS, 2018).

Existem alguns programas de empreendedorismo no exterior, o mais conhecido é o da Junior Achievement Company Program criado em 1919 que tem como objetivo fornecer aos estudantes do ensino médio a chance de treinar e desenvolver habilidades empreendedoras. Outro programa que existe a 20 anos é o BizWorld, o qual o foco é trabalhar com crianças e adolescentes do ensino primário e secundário, com objetivo de ensinar esse público-alvo a administrar um negócio por meio de programas de empreendedorismo (ELERT; ANDERSSON; WENNBERG, 2015; HUBER; SLOOF; VAN PRAAG, 2014).

Pesquisas realizadas nesse ambiente ainda são incipientes, os autores (PETERMAN; KENNEDY, 2003) comentam que há lacunas diante da literatura. Elert, Andersson e Wennerberg (2015) acrescentam que a educação voltada ao empreendedorismo no nível médio não recebe a devida atenção, uma vez que a maior quantidade de estudantes se concentra nesse ambiente, desse modo, faltam pesquisas tornando difícil promover e identificar mecanismos de mensuração para avaliar o aprendizado do empreendedorismo no ensino médio.

Sendo assim a contribuição desta pesquisa é atender essa lacuna de publicações nacionais e internacionais sobre o tema no nível do ensino médio e mensurar a influência que as características empreendedoras e o ambiente escolar têm na intenção empreendedora dos alunos do ensino médio/técnico das Etecs Lauro Gomes e Juscelino Kubitschek de Oliveira. Quanto a contribuição prática, o objetivo é trazer aos gestores e professores informações sobre 
o nível de interesse dos alunos, e os respectivos perfis, e a maneira pela qual o ambiente os influenciam para o empreendedorismo.

Diante disso, a questão de pesquisa deste trabalho é: em que medida as características empreendedoras e o ambiente escolar podem influenciar na intenção empreendedora dos alunos do ensino médio/técnico das Etecs?

Primeiramente este trabalho irá tratar do ensino e da aprendizagem do empreendedorismo com especial atenção ao contexto do ensino médio/técnico. Em seguida, o trabalho irá apresentar o ambiente escolar, analisando as Etecs e suas influências, a partir de suas práticas, na intenção empreendedora dos alunos e, finalmente, a metodologia deste trabalho quantitativo parte de um modelo utilizado por Moraes, Iizuka e Pedro (2018), que vem demonstrando resultados relevantes no ensino superior, porém adaptada para a realidade do ensino médio/técnico. Os dados foram analisados por meio de Modelos de Equações Estruturais com a técnica de Mínimos Quadrados Parciais (PLS-SEM). A amostra foi composta de 384 alunos dos cursos técnicos em Administração, Logística, Desenvolvimento de Sistemas e Secretariado; Ensino Técnico Integrado ao Médio (ETIM) de Mecatrônica, Automação Industrial e Química, e, Ensino Médio Regular das Etecs Lauro Gomes e Juscelino Kubitschek de Oliveira. 
Ao longo de muitos anos, foram realizadas pesquisas sobre como a educação para o empreendedorismo se manifestou ao longo do tempo, um estudo realizado por Katz (2003), mostra uma cronologia que vai desde 1876 a 1999, seguida por outros autores como por exemplo Drucker (2000), Henry, Hill e Leitch (2005), Dolabela (2011), dentre outros.

Até pouco tempo havia uma discussão no meio acadêmico para saber se o empreendedorismo poderia ser ensinado ou se as pessoas já nasciam empreendedoras, Drucker (2000) diz que o empreendedorismo não está relacionado com a genética, e o considera como uma disciplina, sendo assim, como toda disciplina ele pode ser ensinado e aprendido (DOLABELA, 2011; DRUCKER, 2000).

Jamieson (1984 apud HENRY; HILL; LEITCH, 2005) sugeriu 3 categorias para organizar o ensino do empreendedorismo: (1) educação sobre a empresa, (2) educação para empresa e (3) educação na empresa, reconhecendo os diferentes papéis que cada uma delas tem a desempenhar.

A primeira categoria - educação sobre a empresa -, tem o objetivo específico de educar os alunos sobre os vários aspectos da criação e execução de um negócio, principalmente a partir de uma perspectiva teórica. A segunda - educação para a empresa - lida com a preparação dos alunos a serem empreendedores, com o objetivo específico de incentivar a criar e gerir o seu próprio negócio. A última categoria - a educação em empresas -, trabalha principalmente com a formação gerencial para empresários estabelecidos e se concentra em garantir o desenvolvimento futuro de seu negócio (JAMIESON, 1984 apud HENRY; HILL; LEITCH, 2005).

Visto que empreendedorismo pode ser explicado, a pergunta mais relevante a se fazer não é mais se pode ou não ser ensinado e sim: qual a abordagem deveria ser aplicada no ensino? Ou até mesmo, como a aprendizagem do empreendedorismo pode ocorrer?

Na literatura acadêmica, é conhecido que os métodos de aprendizagem utilizados variam consideravelmente e apesar dessa diversidade, existe certo consenso em relação a algumas pedagogias que se mostraram vantajosas para moldar indivíduos empreendedores (BOYLES; COLLEGE, 2012). Contudo, o objetivo deste trabalho não é identificar qual a melhor prática pedagógica, mas evidenciar as diversas existentes.

$\mathrm{Na}$ pedagogia tradicional existe uma contestação quanto a abordagem em atender as necessidades do ensino e da aprendizagem do empreendedorismo, o conhecimento e as habilidades apresentadas pelos métodos teóricos muitas vezes não são transferidos para o ambiente real. Existe uma linha de pensamento com um olhar crítico deste tipo de ensino e aprendizagem, um certo ceticismo em relação a aulas teóricas, acredita-se que as mesmas não 
teriam um efeito esperado quando se trata de um assunto tão dinâmico, pois nesse tipo de metodologia de ensino o aprendizado, normalmente, acontece de maneira previsível, o qual os alunos revisam a teoria e repetem soluções previamente ditadas para problemas abstratos que muitas vezes não refletem a realidade. Portanto, entende-se que trabalhar somente essa abordagem dificulta o aluno a resolver problemas complexos e dinâmicos tipicamente enfrentados no dia a dia das empresas (GIBB, 1987; HONIG, 2004).

Porém, Fiet (2001) traz outro contexto em relação ao ensino teórico, concordando que uma metodologia baseada na teoria é eficiente e que os alunos conseguem adquirir competências e habilidades empreendedoras por meio desse método, mas existem obstáculos encontrados nesse tipo de metodologia como a dependência do aluno em relação as instruções vindas do professor, o professor como detentor do conhecimento e o aluno receptor passivo diante disso.

Quando se trata de ensino e aprendizagem do empreendedorismo o papel do professor precisa ser mediador e não detentor do saber e o aluno ser mais autônomo no processo (RUSKOVAARA et al., 2010).

A abordagem mais utilizada no ensino e aprendizagem do empreendedorismo é o contato experiencial, o qual os alunos aprendem experimentando tanto sucessos como fracassos a fim de criar resiliência diante das condições organizacionais futuras, essa metodologia aumenta a motivação e estimula as dimensões emocionais e intuitiva do empreendedorismo (HONIG, 2004; LAUTENSCHLÄGER; HAASE, 2011).

Esse ensino voltado mais para prática pode ser realizado de diversas maneiras, por meio de palestras, apresentações, estudo de caso com discussão em grupo, criação de planos de negócios, simulações nas quais são projetadas com um conjunto particular de soluções, criação de projetos, os quais oferecem aos alunos a oportunidade de aprender não apenas sobre empreendedorismo mas, além disso, aplicá-lo a partir de cenários da vida real (HENRIQUE; CUNHA, 2008; HONIG, 2004; KNOTTS; COLLEGE, 2011; KURATKO, 2005). Um outro recurso é a utilização de filmes para fins pedagógicos permitindo que os alunos se envolvam tanto intelectualmente e emocionalmente na história e, com isso, serem mais capazes de identificar as ligações entre os detalhes da história e os conceitos ensinados (ILANDER, 2010).

Outra maneira de experienciar esse ensino e aprendizagem é por meio da participação do aluno em empresas juniores dentro do ambiente escolar, pois essas fornecem uma estrutura para coordenar métodos de ensino experienciais com oportunidades de alcance comunitário, resultando em melhor aprendizagem e até proporcionando desenvolvimento econômico local, esse tipo de experiência pode aperfeiçoar as habilidades e competências gerenciais 
(HENRIQUE; CUNHA, 2008; KNOTTS; COLLEGE, 2011). Ou seja, o aluno aprende a partir da assessoria fornecida às empresas da comunidade local, utilizando seu conhecimento orientado em sala de aula por meio do suporte de professores, estando em constante formação ao longo dessa vivência.

Além dessas práticas pedagógicas utilizadas em salas de aula, o ensino e a aprendizagem do empreendedorismo podem acontecer fora do ambiente escolar, como por exemplo, visitas técnicas à empresas e entrevistas com empresários, essas práticas têm grande potencial de ampliar o ambiente de aprendizagem e enriquecer o ensino, pois por meio do contato da vivência com empreendedores e empresas o aluno consegue visualizar a realidade do dia a dia de uma organização (RUSKOVAARA et al., 2010).

As atividades experienciais não apenas melhoram o aprendizado, mas também, ajudam o aluno a tomar decisões mais informadas e conscientes e melhorar sua capacidade de comunicação (KNOTTS; COLLEGE, 2011).

Em resumo, o 'modelo experiencial' é projetado para ajudar os alunos a aprenderem com os erros, a tolerarem o risco e desenvolver algumas habilidades gerenciais necessárias de um território desconhecido.

Além das práticas pedagógicas citadas, ter uma disciplina fixa voltado ao tema no currículo do curso pode favorecer a conscientização dos alunos e fornecer-lhes apoio prático, além do mais, o processo de ensino e aprendizagem acontece de maneira longitudinal, planejada e organizada (BOYLES; COLLEGE, 2012; CHEUNG; AU, 2010; RUSKOVAARA et al., 2010).

O professor é um agente muito importante nesse processo de ensino e aprendizagem do empreendedorismo, já que é ele que fará a operacionalização da educação, encontrando as melhores práticas pedagógicas conforme o perfil dos alunos. Os professores selecionam as abordagens de trabalho, e são suas as tarefas de ensiná-las, mas principalmente de orientar o trabalho e a aprendizagem (RUSKOVAARA et al., 2010).

O professor deve criar situações e um ambiente favorável para que o aluno seja o protagonista do seu conhecimento, em alguns momentos do processo de ensino e aprendizagem os papéis de aluno e professor se invertem, desse modo, é o aluno que gera conhecimento, isso acontece quando o professor cumpri a tarefa de conduzir o processo de auto aprendizado do aluno, tornando-se um facilitador. O professor pode agir de duas maneiras, a primeira como conselheiro, o qual seu papel é motivar a confiança do aluno, incentivar a auto descoberta e desenvolver nele a capacidade de resolução de problemas; na segunda maneira o professor toma 
a postura de um consultor, sua atribuição é ofertar sua expertise sobre o mundo dos negócios (DOLABELA, 2011; GARAVAN; O'CINNEIDE, 2004).

O professor também se depara com muitos desafios nesse processo de ensino e aprendizagem, tais como: encontrar métodos de aprendizagem inovadores, expectativa dos alunos perante o método utilizado, melhores conteúdos programáticos e a deficiência nos recursos institucionais da infraestrutura escolar, como por exemplo, salas e laboratórios adequados, uso de tecnologia, dentre outros (GARAVAN; O'CINNEIDE, 2004; HENRIQUE; CUNHA, 2008; HENRY; HILL; LEITCH, 2005).

Conforme apresentado, o processo de ensino e aprendizagem do empreendedorismo ocorre por meio de diversas metodologias, além disso, foi elucidado outro fator importante nesse desenvolvimento; a pessoa do professor no papel de não mais como o detentor do conhecimento, mas como um facilitador para que o aluno seja o protagonista nesse percurso.

Essas práticas citadas foram apresentadas em artigos e estudos que citam cursos e treinamentos principalmente utilizando o ensino superior como 'laboratório' dessas metodologias, essas pesquisas foram realizadas para contextualizar de maneira global o ensino e a aprendizagem do empreendedorismo, porém, o foco deste trabalho é apresentar como isso ocorre em um plano anterior ao nível superior, ou seja, no nível médio, que será discutida na próxima seção.

\subsection{O ENSINO E A APRENDIZAGEM DO EMPREENDEDORISMO NO NÍVEL MÉDIO}

A literatura acadêmica nacional e internacional sobre o empreendedorismo é voltada predominantemente para cursos de graduação e pós-graduação, o conteúdo e as atividades são trabalhados de tal maneira que o estudante relacione o empreendedorismo com a criação de novos negócios (FAYOLLE; LIÑÁN, 2014; KURATKO, 2005; MORAES; IIZUKA; PEDRO, 2018; ROCHA; FREITAS, 2014).

Contudo, o estudante que chega ao ensino superior não ingressa sem trazer consigo uma bagagem cheia de experiências, pois, eles sofreram influências do meio em que viveram (IIZUKA; MORAES, 2014). Desta forma, o ensino médio é um momento, o qual o jovem tem diversas experiências que impactarão em seu futuro.

Muito antes de ser feito pesquisas acadêmicas sobre o empreendedorismo no ensino médio, já existia a iniciativa como o da Júnior Achievement Company Program criado em 1919, o programa mais conhecido e renomado no exterior de ensino do empreendedorismo que tem como objetivo fornecer aos estudantes do ensino médio a chance de treinar e desenvolver 
habilidades empreendedoras, fazendo com que os alunos vivenciem todo o ciclo de vida de uma empresa por meio de uma abordagem de 'aprender fazendo', esse programa incentiva os alunos a resolverem um problema da sua comunidade local, eles descobrem como uma empresa funciona e obtém uma visão de como seus talentos poderiam ser usados para montar um negócio. Outro programa que já está presente em mais de 100 países é o BizWorld, seu foco é em crianças e adolescentes do ensino primário e secundário. O programa é recente, há 20 anos trabalha com o objetivo de ensinar esse público a administrar um negócio a partir de programas de empreendedorismo, capacitando-os e despertando o espírito empreendedor (ELERT; ANDERSSON; WENNBERG, 2015; HUBER; SLOOF; VAN PRAAG, 2014).

As pesquisas realizadas nesse ambiente ainda são incipientes, Peterman e Kennedy (2003) comentam que existe uma lacuna diante da literatura acadêmica; os autores Xu, Ni e Ye (2016) afirmam que essa escassez de pesquisa não deveria existir, principalmente por acreditarem que nesse nível de ensino é o estágio ideal para fomentar o empreendedorismo.

No contexto nacional, foram localizados três pesquisas: uma delas tem por objetivo de investigar as competências que compõem a Educação Empreendedora, contudo ela aborda os 3 níveis de ensino: fundamental, médio e superior (ZAMBON, 2014); o segundo estudo elabora uma proposta para inserção de uma disciplina de empreendedorismo em uma instituição de ensino nível médio (MAYER, 2001); e a última utilizou o mesmo objeto de pesquisa (ETEC) e se propôs a investigar se a educação profissional desenvolve competências empreendedoras, a análise se restringiu aos alunos egressos (PEREIRA, 2018).

No âmbito internacional as pesquisas de Birdthiste, Hynes e Fleming (2007); Paço et al. (2011b); Peterman e Kennedy (2003); e, Xu, Ni e Ye (2016) afirmam sobre a relevância de estudar esse tema no ensino médio. Os autores Filion (1994); Kourilsky e Walstad (1998); e Lee, Chang e Lim (2005) declaram que as fases da infância e adolescência são frequentemente identificadas como os períodos preferenciais para o desenvolvimento de atitudes positivas em relação ao empreendedorismo e a aquisição de conhecimento básico sobre o tema.

Para corroborar tal afirmação, estudos realizados na Noruega e Suécia com alunos de nível médio em programas que envolveram a educação para o empreendedorismo, declararam que esse público é mais disposto a desenvolver atitudes empreendedoras. Outro estudo realizado na África do Sul confirmou que o sistema de educação formal contribui muito para o desenvolvimento de características empreendedoras (HANCOCK, FITZSIMONS 2004 apud PAÇO et al, 2011). Projetos de ensino como esses tem como objetivo propiciar aos alunos do ensino médio o ensejo de treinar e desenvolver competências empreendedoras (ELERT; ANDERSSON; WENNBERG, 2015; JOHANSEN, 2010; PAÇO et al., 2011b). 
Outros países também estão investindo na educação para o empreendedorismo nos ensinos pré-universitários, a Finlândia por exemplo, introduziu em seu currículo no ensino primário e secundário; nos Países Baixos existem várias atividades relacionadas com o empreendedorismo; na Alemanha, Áustria e Suíça ainda não existe uma estrutura sólida, mas existem esforços para a inserção dessa educação. Como visto, a Europa vem desenvolvendo várias iniciativas pedagógicas inovadoras nos últimos anos (COMMISSION, 2006; PAÇO et al., 2011b).

No Brasil, existem projetos paralelos à educação formal que auxiliam no ensino do empreendedorismo, como por exemplo o projeto Fazendo Acontecer do Instituto do Prof. Dr. José Dornelas que tem como objetivo de levar o aluno a aprender sobre o empreendedorismo a partir de metodologias diferenciadas e mais dinâmicas, e também por meio de oficinas que visam proporcionar a vivência prática que estimulem o empreendedorismo em crianças e adolescentes (INSTITUTO FAZENDO ACONTECER, 2018). Outro projeto sobre o assunto é do Serviço Brasileiro de Apoio às Micro e Pequenas Empresas (SEBRAE), a iniciativa intitulada como Educação Empreendedora tem como objetivo difundir o empreendedorismo nas instituições de ensino de todos os níveis de escolaridade (SEBRAE - SERVIÇO BRASILEIRO DE APOIO ÁS MICROS E PEQUENAS EMPRESAS, 2018).

Já na educação formal, pesquisas como dos autores Birdthistle, Hynes e Fleming (2007) e Paço et al. (2011a) avançam na ideia de que o ensino do empreendedorismo afeta as atitudes dos alunos, influenciando-os até mesmo na direção de sua carreira futura, como também na sua propensão ao empreendedorismo quando se tornam adultos, embora os autores não tenham testado essa afirmação empiricamente. A inclusão do empreendedorismo no currículo escolar traz vantagens no processo de ensino e aprendizagem, tais como: a integração de uma variedade de assuntos organizacionais, oferecendo aos alunos uma experiência de aprendizagem em relação ao mundo dos negócios; promoção de novas habilidades e competências empreendedoras; e um aumento na transferência de conhecimento da escola para o mercado (FAOITE et al., 2003).

Essa necessidade também foi visualizada pela ótica dos próprios alunos, um estudo realizado por Cheung e $\mathrm{Au}$ (2010) demonstrou que os estudantes do ensino médio valorizaram muito a educação para o empreendedorismo, e acreditavam que mais tempo deveria ser gasto ensinando empreendedorismo nas escolas.

Sendo assim, as pesquisas, sobre o empreendedorismo no ensino médio, tratam o assunto por meio de duas correntes; uma delas de forma lúdica, equilibrada e até mesmo subjetiva para que a experiência com o empreendedorismo contribua de maneira positiva, 
desenvolvendo características e competências que o ajudarão em qualquer contexto da vida (INSTITUTO FAZENDO ACONTECER, 2018; PAÇO et al., 2011b); já a outra corrente trabalha o empreendedorismo de maneira mais clássica e aplicada, no qual o ambiente proporcionará o conhecimento técnico por meio de oficinas, projetos e atividades empreendedoras, não com a mesma intensidade realizada no nível superior, a abordagem no nível médio/técnico tem a finalidade de preparar o jovem para o mercado profissional (BONNETT; FURNHAM, 1991; FAOITE et al., 2003; HICKIE, 2011).

Uma questão central que surge sobre o ensino e a aprendizagem do empreendedorismo aos estudantes do ensino médio, corresponde, as metodologias utilizadas para esse processo. Um dos objetivos desse ensino no nível médio é fornecer aos alunos a oportunidade de experimentar os aspectos práticos por meio do desenvolvimento dinâmico e criativo de ideias (FAOITE et al., 2003).

Para entender melhor essa realidade, serão citados 2 exemplos praticados por Etecs abordando 2 ferramentas para o processo de ensino e aprendizagem de empreendedorismo dos seus alunos: (1) a criação de uma empresa júnior e o (2) plano de negócio. Ter uma empresa júnior é algo comum no ensino superior, porém no ensino técnico essa abordagem ainda é muito recente.

A Etec Gildo Marçal Bezerra Brandão da cidade de Perus, implantou uma empresa júnior em 2013 com o objetivo de levar aos alunos a experiência da vida profissional a partir da aplicabilidade da aprendizagem de sala de aula, capacitando-os para a inserção no mercado de trabalho, como também colaborando para o desenvolvimento econômico e social do entorno. Essa experiência proporcionou aos alunos um amadurecimento profissional por meio da autonomia para tomada de decisões quanto as parcerias e projetos e a consciência social em olhar a comunidade local e buscar a auto sustentabilidade financeira e econômica. Tudo isso foi possível a partir do auxílio de professores na orientação dos projetos realizados, e com o aluno sendo o protagonista de cada ação (IIZUKA, 2015).

Outro exemplo foi a Etec Antonio Devisate da cidade de Marília, criando o projeto Plano de Negócio na Prática em 2011, o qual a finalidade era aprimorar o aprendizado do aluno por meio da criação de uma empresa fictícia, o desafio era realizar um plano de negócio de uma empresa de rosquinhas. O projeto só foi possível mediante o envolvimento de professores de outras disciplinas devido as várias etapas que o plano de negócios exige. Nas apresentações os alunos utilizaram outras ferramentas como o Canvas e o Pitch e os trabalhos foram demonstrados para toda comunidade escolar. Em algumas turmas os alunos escolheram o próprio tema que era, muitas vezes, ligado a objetivos pessoais. Em depoimentos, os estudantes 
contaram como foi a experiência dessa atividade levantando alguns aspectos como: noção muito mais abrangente da abertura de uma empresa, algo que era considerado complexo se tornou de fácil compreensão, assim também, a visão de como criar e administrar uma empresa (IIZUKA, 2015).

Com o intuito de buscar mais elementos que pudessem contribuir na influência do ambiente escolar na intenção empreendedora dos estudantes, tomou-se a inciativa de realizar uma entrevista com Ivone Marchi Lainetti Ramos, professora e atualmente diretora da Etec Sebrae e da Etec de Guarulhos, que está no CPS desde de 1991, participou na elaboração no prêmio FEI Inova Paula Souza de Experiências Inovadoras de Aprendizagem, parceria FEI e CPS para premiar iniciativas inovadoras de alunos e professores do CPS, ganhadora do prêmio Governador Mário Covas de boas práticas e modernização da gestão pública, com experiência em consultoria de negócios para incubadoras e conhecimento em metodologias tais como: Design Thinking, Modelo Canvas, Pitch e Plano de Negócios.

Segundo Ramos (2018) o ensino e a aprendizagem do empreendedorismo no ensino médio também utilizam as mesmas ferramentas pedagógicas, porém a maneira como elas são abordadas em sala de aula precisa ser diferente, as ferramentas precisam ser adaptadas para a linguagem do aluno trazendo realidades não tão distantes. O processo de ensino e aprendizagem deve levar em consideração o aluno e a maneira pela qual aprende (informação verbal). ${ }^{1}$

Ramos (2018) afirma que empreendedorismo possa ser o caminho para mudar a realidade de um entorno, uma comunidade, de fazer diferença, gerar uma qualidade de vida e oferecer uma oportunidade para quem não a vislumbrava. $\mathrm{O}$ aluno motiva-se ao participar da transformação dessa realidade, pois ele consegue visualizar e até mensurar o impacto gerado por sua ação. Atividades e projetos, fora desse contexto, levam ao aluno a ter um contato muito distante da realidade, o adulto consegue visualizar e entender, mas o adolescente tem que ser imediato, ainda que pequeno, ele precisa ver que valeu a pena e ele proporcionou um resultado ${ }^{1}$.

A exemplo desse comentário, a Etec Dr. Geraldo José Rodrigues Alckmin da cidade de Taubaté, criou em 2014 o projeto Olhar Social que tem como objetivo arrecadar e doar armações de óculos para beneficiar os moradores locais que não tem condições financeiras de aquisição. Nesse projeto, os alunos conseguiram montar um ciclo que começa desde a arrecadação das armações até a entrega ao beneficiado, nesse processo foram realizadas parcerias com ONGs para serem postos de arrecadação e distribuição e com óticas da região para a confecção das lentes para armação. O resultado dessa ação trouxe uma economia para os

\footnotetext{
${ }^{1}$ Informação verbal concedida por Ivone Marchi Lainetti Ramos, no dia 13 de novembro de 2018 em entrevista.
} 
indivíduos em torno de 30\% a 70\%, já para os alunos esse processo de ensino e aprendizagem auxiliou na obtenção de competências como trabalhar em equipe, tomada de decisão e criatividade com um impacto motivador, despertando uma perspectiva empreendedora e humanística, estimulando outros a realizarem projetos similares como esse na comunidade local (IIZUKA, 2015).

Diante da fala da entrevistada e dos relatos de experiências vividos por essas Etecs, o ensino e a aprendizagem do empreendedorismo no nível médio/técnico indicam ser distinto do nível superior, o adolescente consegue aprender mais quando o método o remete a experiências empreendedoras as quais ele consegue se visualizar durante o processo, ou para a realidade a qual ele está inserido .

É necessário também ter um ambiente propício para que o ensino e a aprendizagem ocorram. O objetivo desse trabalho é verificar em que medida o ambiente escolar do ensino médio influencia na intenção empreendedora, isto será discutido no próximo capítulo com a instituição que faz parte desse ambiente escolhido para o estudo.

\section{$2.2 \mathrm{O}$ ENSINO E A APRENDIZAGEM MEDIDOS PELAS CARACTERÍSTICAS EMPREENDEDORAS}

Em relação a capacidade de se ensinar o empreendedorismo, alguns assuntos podem ser desenvolvidos, como por exemplo, contabilidade, marketing, gerenciamento e desenvolvimento de plano de negócios, porém alguns não são tão fáceis de instruir, como por exemplo, a autoconfiança, persistência, criatividade e inovação dentre outras habilidades e competências, essas características dependem de outros fatores e são aspectos que ainda não foram devidamente apoiados por métodos de ensino apropriados (HENRY; HILL; LEITCH, 2005; MORAES; IIZUKA; PEDRO, 2018).

Esses, dentre outros atributos, são chamados de características empreendedoras, um conjunto de competências e atitudes comportamentais comuns encontradas em pessoas que exercem atividades empreendedoras que por sua vez formam o perfil empreendedor (SCHMIDT; BOHNENBERGER, 2009).

A avaliação do processo de ensino e aprendizagem do empreendedorismo acontece com o intuito de medir o impacto que esse ensino causa nos alunos. A literatura apresenta abordagens para realizar essa mensuração, como por exemplo, orientação empreendedora, perfil empreendedor, potencial empreendedor, intenção empreendedora, dentre outros 
(GATEWOOD et al., 2002; PETERMAN; KENNEDY, 2003; ROCHA; FREITAS, 2014; SCHMIDT; BOHNENBERGER, 2009).

Essa pesquisa tomará como abordagem para mensurar o impacto do ensino e aprendizagem, a intenção empreendedora, ou seja, o quanto esse indivíduo está propenso em abrir um negócio, por meio das características empreendedoras (KRUEGER; BRAZEAL, 1994; KRUEGER; REILLY; CARSRUD, 2000).

A literatura menciona alguns modelos para tal mensuração e os mais utilizados são o modelo de Ajzen da teoria do comportamento planejado que sugere a importância relativa dos três antecedentes da intenção - atitude em relação ao comportamento, normas sociais e controle comportamental percebido -, ou seja, quanto o ambiente influencia na intenção empreendedora, por outro lado, o modelo de Shapero diz que a intenção de iniciar um negócio deriva de percepções de desejabilidade e viabilidade e de uma propensão para atuar em oportunidades (BIRD, 1988; ENGLE et al., 2010; KLAPPER; LÉGER-JARNIOU, 2006; TURKER; SONMEZ SELCUK, 2009). Contudo, essa pesquisa se baseará no modelo de Ajzen.

Desde o trabalho seminal de McClelland (1961), estudos têm sido realizados com a finalidade de compreender as características empreendedoras. Os autores Gupta e Fernandez (GUPTA; FERNANDEZ, 2009) por meio de sua pesquisa encontraram 92 características, tais como, curioso, simpático, falador, capacidade de liderança, criativo, ambicioso, intuitivo, persistente, etc.

A partir das características empreendedoras os pesquisadores têm utilizado métodos quantitativos. Para os autores Rocha, Augusta e Freitas (2014) o conjunto de certas características permitiu avaliar a eficiência do processo de ensino aprendizagem do empreendedorismo, já os autores Schmidt e Bohnenberger (2009) tiveram o intuito de avaliar a relação entre o perfil empreendedor e o desempenho organizacional, e os autores Moraes, Iizuka e Pedro (2018) utilizaram para medir a intenção empreendedora.

O modelo, a escala e os indicadores que serão utilizados neste trabalho, estão baseados na pesquisa dos autores Moraes, Iizuka e Pedro (2018), os quais construíram a partir dos trabalhos de Rocha, Augusta e Freitas (2014) e Schmidt e Bohnenberger (2009) entre demais literaturas. Com isso, o instrumento foi criado para mensurar a intenção empreendedora de estudantes do ensino superior.

Esta pesquisa utilizará o mesmo modelo e escala, porém com algumas adaptações, pois o público-alvo será o ensino médio. Considerando-se a literatura nacional e internacional sobre o tema, não se encontrou uma pesquisa congênere publicada. Nesse contexto, os autores Elert, Andersson e Wennberg (ELERT; ANDERSSON; WENNBERG, 2015) comentam que a 
educação voltada ao empreendedorismo no nível médio é dada pouca atenção, e devido a isso faltam pesquisas tornando difícil identificar mecanismos de mensuração para avaliar quais habilidades e competências que esse ensino pode promover.

Sendo assim, as características empreendedoras que formarão os construtos que irão auxiliar na mensuração da intenção empreendedora serão as seguintes: Autoeficácia (AE), Assumir Riscos (AR), Intenção Empreendedora (IE), Inovação (IN), Planejamento (PL) e Sociabilidade (SO)

A autoeficácia refere-se ao grau em que as pessoas acreditam que podem organizar e efetivamente executar ações para produzir determinadas realizações (BANDURA, 1986; CHEN; GREENE; CRICK, 1998). No contexto do empreendedorismo, a autoeficácia é tida como a força que uma pessoa tem em acreditar que ela é capaz de realizar com sucesso vários papéis e tarefas para abrir e gerenciar o seu próprio negócio (CHEN; GREENE; CRICK, 1998).

A literatura vem demonstrando que a autoeficácia está intimamente relacionada a intenção de empreender, sendo ela um preditor, ou seja, quanto maior a autoeficácia de um indivíduo, maior é sua intenção de empreender (CHEN; GREENE; CRICK, 1998; PIPEROPOULOS; DIMOV, 2015; PITTAWAY et al., 2011).

A variável autoeficácia traz consigo características comportamentais que formam esse construto, os autores Moraes, Iizuka e Pedro (2018) utilizaram as seguintes características: sociabilidade, planejamento, liderança, inovação e capacidade para assumir riscos. As características estabelecem motivações individuais que estão ligadas a elementos fundamentais na intenção empreendedora, que interagem formando uma sinergia auxiliando sua mensuração (SAEED et al., 2015).

O construto da sociabilidade traz o seguinte entendimento: já que os empreendedores estão inseridos em um contexto social, eles estão sujeitos a tarefas que envolvem elementos de socialização, tais como: comunicar-se efetivamente com diversas pessoas, realizar parcerias para o desenvolvimento de relacionamentos e redes de negócios, estabelecer confiança e legitimidade em suas negociações. Outro ponto que os autores Markman e Baron (2003) afirmam é que indivíduos com habilidades sociais - baseado em extensas redes sociais, status, vínculos pessoais e referências - são mais propensos a receber investimentos em seus negócios do que indivíduos com baixa habilidades sociais.

O ato de planejar é uma ação necessária para qualquer atividade a ser realizada, praticar o planejamento no empreendedorismo é poder se antecipar a acontecimentos e ter uma visão futura do empreendimento, o planejamento permite que o indivíduo consiga visualizar o que 
quer alcançar e com isso essa característica torna-se viável para compor o perfil empreendedor (DORNELAS, 2012; FILION, 2000).

A liderança é vista como a prática de orientar pessoas e a capacidade de inspirar e motivá-las dentro de uma organização, isto faz com que essa característica seja importante, pois é por meio da liderança que o indivíduo tem o comprometimento dos funcionários na realização de tarefas, da proatividade, autoconfiança e visão, para que seu objetivo possa ser alcançado com ajuda de demais pessoas (RENKO et al., 2015; VECCHIO, 2003).

A característica empreendedora inovação tem seu papel no perfil empreendedor, pois o empreendedor com sua criatividade e visão introduz novos produtos e serviços, cria novas formas de organização e explora novos recursos e materiais afetando a realidade econômica existente, empreendedores eficazes tendem a ser inteligentes na criação de inovações e na conversão dessas em produtos e serviços que atendam às necessidades do mercado (DORNELAS, 2012; PETERSON; LIMBU, 2010).

E por fim, a capacidade de assumir riscos é algo inerente ao empreendedor (CARLAND; HOY; CARLAND, 1988). Na literatura, alguns autores observaram que indivíduos com maior propensão ao risco têm maior probabilidade de querer seguir uma carreira empreendedora, porque se sentem mais confiantes de que podem cumprir os papéis e realizar as tarefas necessárias para ter sucesso como empreendedor (NEWMAN et al., 2019; ZHAO; SEIBERT; HILLS, 2005).

Sendo assim, as hipóteses que serão testadas quanto as características empreendedoras serão:

Quadro 1 - Hipóteses do Estudo

\begin{tabular}{|l|l|}
\hline Hipóteses & Descrição \\
\hline H1 & A sociabilidade influencia positivamente a autoeficácia. \\
\hline H2 & A capacidade de planejamento influencia positivamente a autoeficácia. \\
\hline H3 & A capacidade de liderança influencia positivamente a autoeficácia. \\
\hline H4 & A capacidade de inovação influencia positivamente a autoeficácia. \\
\hline H5 & Assumir riscos calculados influencia positivamente a autoeficácia. \\
\hline H6 & A autoeficácia influencia positivamente a intenção empreendedora. \\
\hline
\end{tabular}

Fonte: Autora “adaptado de” Moraes, Iizuka e Pedro, 2018, p. 233.

As hipóteses correspondentes ao ambiente escolar serão apresentadas no capítulo a seguir. 


\section{AMBIENTE ESCOLAR}

O ambiente incorpora as condições físicas e de aprendizagem que existem internamente no estabelecimento educacional, é por meio desse ambiente que o ensino e a aprendizagem acontecem. É importante que todos os agentes envolvidos trabalhem em prol de um ambiente propício à aprendizagem (BIRDTHISTLE; HYNES; FLEMING, 2007).

Quando se trata do ambiente de ensino a Constituição Federal de 1988 estabelece um tripé formativo que envolve ensino, pesquisa e extensão, o qual o ensino é caracterizado pelo currículo escolar e por meio das práticas didáticas pedagógicas que proporcionam ao aluno base para seu desenvolvimento acadêmico, logo, a pesquisa tem como objetivo a realização de uma investigação para solucionar uma problemática existente e reúne atividades como iniciação cientifica, artigos e trabalhos de conclusão de curso, e por fim, a extensão tem o intuito de estabelecer uma relação com a comunidade na qual está inserida e tem como práticas, palestras, eventos, oficinas e seminários (MOITA; ANDRADE, 2009; MORAES; IIZUKA; PEDRO, 2018; SCHMIDT GODOY; ANTONELLO, 2009).

Porém, essa é uma realidade utilizada no ensino superior, o qual essas divisões estão bem delimitadas, contudo, no ensino médio/técnico essas três áreas não são tão perceptíveis e o foco se concentra mais no ensino do que na pesquisa e extensão, existem atividades relacionadas as outras duas áreas, entretanto, não com tanta intensidade.

Nesse capítulo será descrito qual é esse ambiente, sua história e importância, seu impacto na educação e, principalmente a instituição que faz parte deste estudo.

\subsection{CENTRO PAULA SOUZA}

Para verificar se o ambiente escolar afeta a intenção empreendedora, será estudado duas escolas (Etecs) de uma rede de ensino do Estado de São Paulo: o Centro Paula Souza (CPS), uma autarquia criada em 1969 com a ideologia daquele que deu seu nome, Antonio Francisco de Paula Souza, nascido no município paulista de Itu, (1843 - 1917), era conhecido por suas ideias e por ser liberal a favor da república e do fim da escravatura, um engenheiro que estudou na Alemanha e Suíça e tinha como objetivo trazer para o Brasil um ensino que estimulasse o crescimento econômico e social. Foi ele quem criou a Escola Politécnica da Universidade de São Paulo (Poli/USP) e trabalhou prontamente no desenvolvimento da infraestrutura do país, com suas obras. Participou da política atuando como deputado estadual e depois como ministro 
das Relações Exteriores e da Agricultura no mandato do presidente Floriano Peixoto (CARVALHO, 2011; SOUZA, 2015).

Antonio Francisco de Paula Souza, era considerado um homem visionário e como educador sempre argumentou positivamente sobre o papel da escola como meio de formação de profissionais. Com isso, a vida de Paula Souza vai ao encontro com a missão da instituição que o homenageou dando o seu nome, que é "promover a educação pública profissional e tecnológica dentro de referenciais de excelência, visando o desenvolvimento tecnológico, econômico e social do Estado de São Paulo" (SOUZA, 2015).

O início do CPS está atrelado com o surgimento do parque industrial e a necessidade de oferecer mão de obra qualificada para os diversos setores produtivos. Diante disso, o Governo de São Paulo mediante decreto cria a autarquia que oferecerá ensino profissional e gratuito de cursos superiores de tecnologia. Na década de 80, o CPS recebe em sua estrutura as primeiras escolas profissionais de nível médio que estavam espalhadas, pelas diversas parcerias firmadas entre os governos federal, estadual e municipal, formando naquele momento a maior rede de ensino profissional gratuito da América Latina (CARVALHO, 2011; SOUZA, 2015).

Atualmente, respondendo à Secretaria de Desenvolvimento Econômico, Ciência, Tecnologia e Inovação (SDECTI), o CPS administra 66 Faculdades de Tecnologia (Fatecs) e 223 Escolas Técnicas Estaduais (Etecs), além de cursos no ambiente da Educação a Distância (EaD) em todos os níveis de ensino (CARVALHO, 2011; SOUZA, 2015).

No que se refere ao objeto de estudo dessa dissertação, as Etecs estão entre as melhores escolas públicas, no último resultado divulgado em 2017, resultado este que vem se repetindo e melhorando a cada ano, as Etecs ficaram entre as 60 primeiras escolas públicas do Estado de São Paulo, considerando as redes municipal, estadual e federal, 46 são Etecs, das 46 escolas técnicas 11 são da Região Metropolitana de São Paulo, 13 são exclusivamente da Capital e 8 unidades são da Região de Campinas. Outra avaliação realizada foi das 20 melhores públicas da Capital, dessas 19 são Etecs (SOUZA, 2015, 2017a).

Outro indicador de qualidade é o Sistema de Avaliação Institucional (SAI), esse sistema é uma pesquisa realizada anualmente em todas as Etecs com alunos, professores, funcionários, pais de alunos e alunos egressos para avaliar vários aspectos escolares e pedagógicos como, adequação do espaço físico e instalações, práticas pedagógicas adotadas pela escola, clima organizacional, ensino e aprendizagem, dentre outros. Todas as informações são verificadas e analisadas por uma área responsável, o objetivo é buscar a melhoria da qualidade de ensino e com base nos resultados, o setor de administração das Etecs pode identificar os pontos positivos 
e negativos de suas escolas e determinar estratégias para melhorar o desempenho delas (SOUZA, 2015, 2017a).

Para ingressar nas Etecs, é necessária a realização de uma prova de conhecimentos gerais, chamada de vestibulinho, que ocorre a cada semestre para os cursos técnicos, e anualmente para o ensino médio e cursos técnicos integrados ao ensino médio.

No Ensino Técnico, são oferecidos 140 cursos, divididos em 12 eixos tecnológicos: Ambiente e Saúde; Controle e Processos Industriais; Desenvolvimento Educacional e Social; Gestão e Negócios; Informação e Comunicação; Infraestrutura; Produção Alimentícia; Produção Cultural e Design; Produção Industrial; Recursos Naturais; Segurança; e, Turismo, Hospitalidade e Lazer (Apêndice A). Os eixos tecnológicos são divisões para agrupar os cursos técnicos conforme suas características científicas e tecnológicas. A divisão dos cursos por eixo é estabelecida pelo Catálogo Nacional de Cursos Técnicos, elaborado pelo Ministério da Educação (SOUZA, 2017c, 2017d).

\section{Gráfico 1 - Quantidade de Cursos por Eixos Tecnológicos}

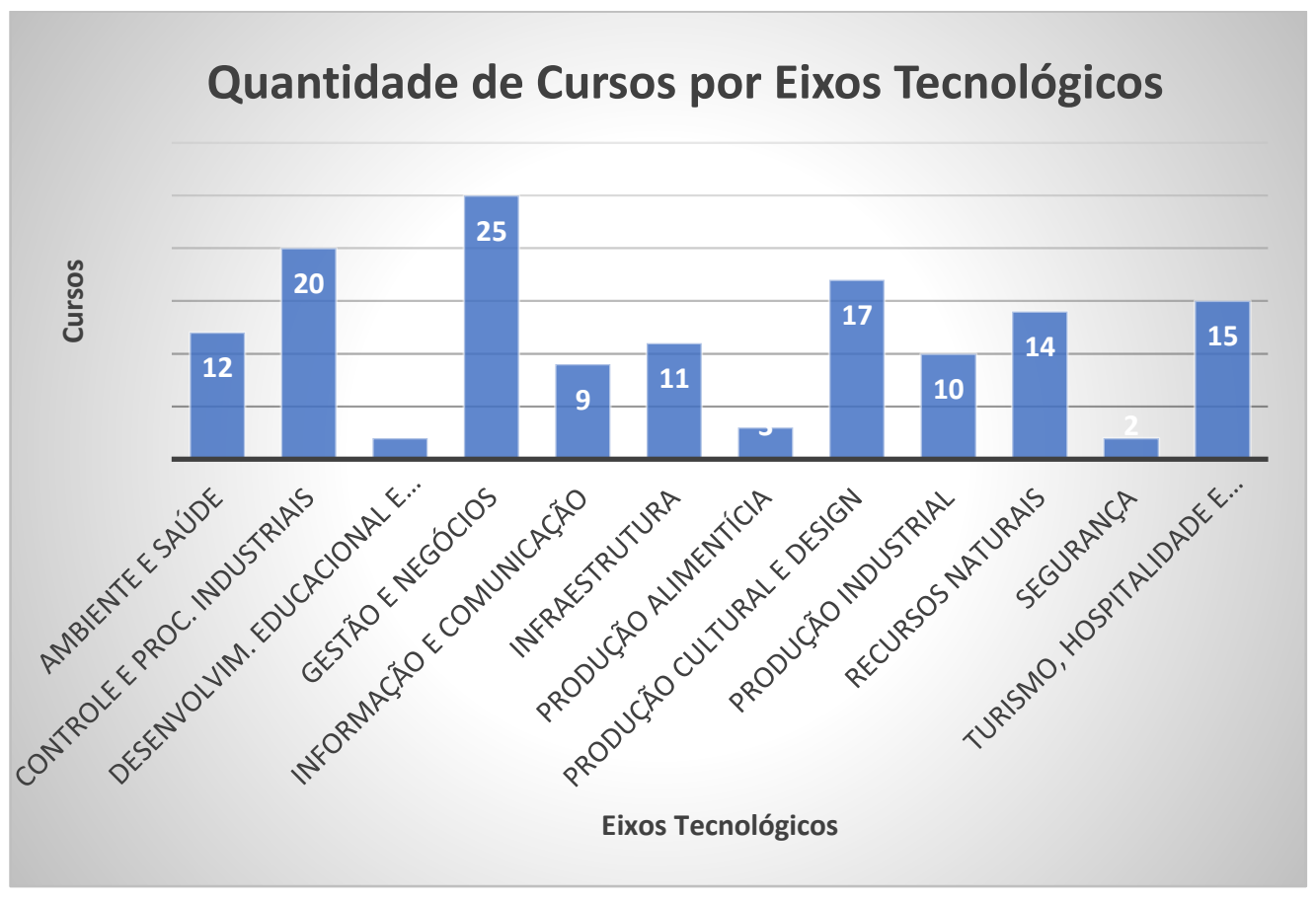

Fonte: Autora.

O ensino técnico nível médio no CPS é ofertado em modalidades: presencial, a distância, integrada ao ensino médio e à educação de jovens e adultos (EJA), em 2017 foram 207.507 mil matriculados, distribuídos conforme gráfico 2 (SOUZA, 2017a). 
Gráfico 2 - Alunos por Eixo Tecnológico

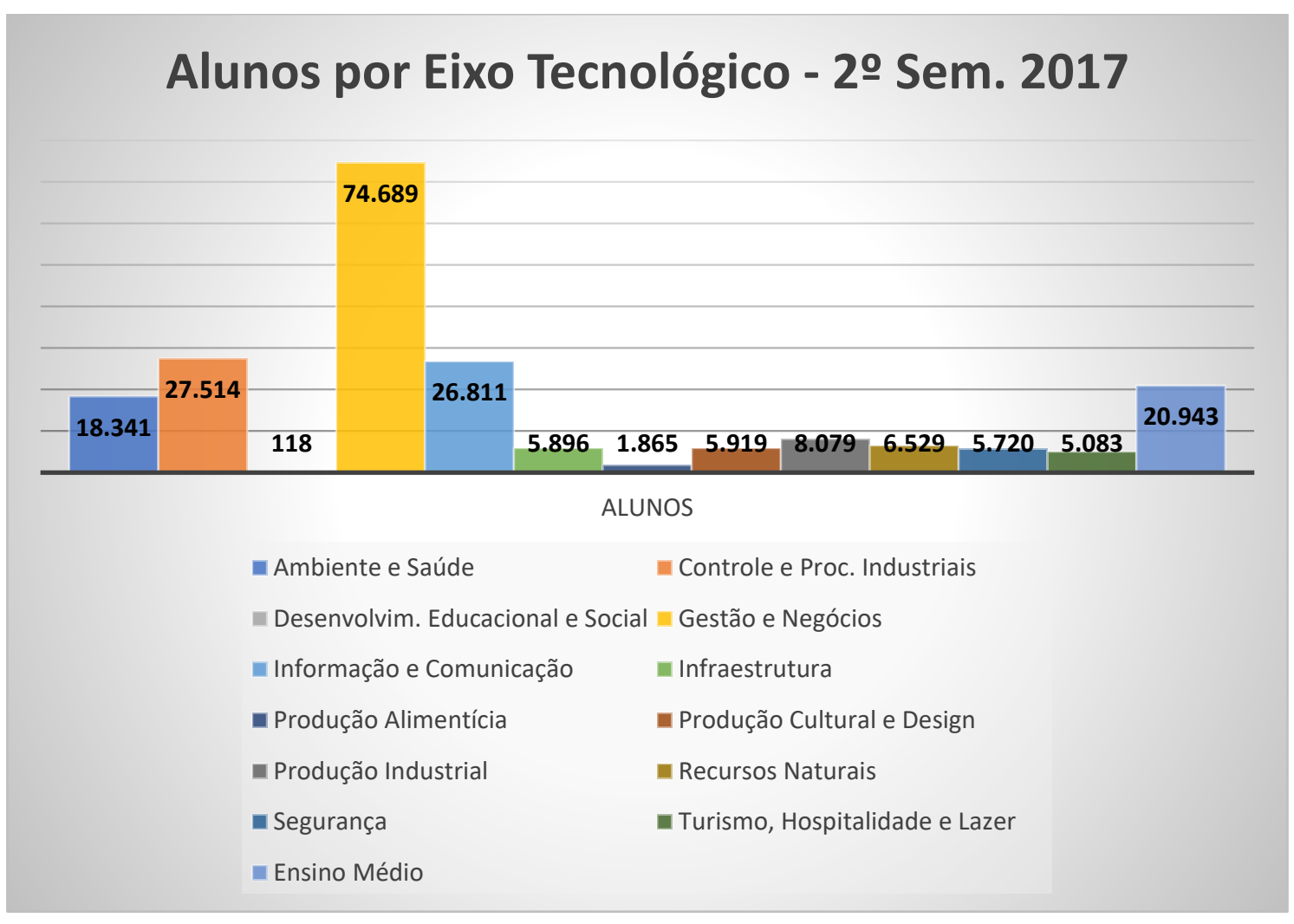

Fonte: Autora.

Atualmente, o CPS é formado por 223 Escolas Técnicas Estaduais, 1 Grupo de Estudos da Educação a Distância - Cetec, 138 classes descentralizadas - Convênios CPS, 116 classes descentralizadas do Projeto Expansão Ext/ Etec/EE e 22 classes descentralizadas do Projeto Expansão Ext/Etec/CEU que atendem, atualmente, 291 municípios do Estado de São Paulo (SOUZA, 2015; ZANIRATO, 2017).

Como visto, o CPS reúne uma diversidade de escolas espalhadas pelo estado de São Paulo, cada uma delas vivenciando uma realidade diferente na região onde está localizada (Anexo A - Mapa das Etecs). Variáveis como contexto socioeconômico e cultural, perfil dos alunos, diferenciação dos cursos e modalidades oferecidos, e corpo docente, trazem para pesquisa um ambiente escolar diversificado.

Outro ponto relevante a ser observado quando abordado a diversidade desse ambiente escolar é a estrutura que cada Etec dispõe, desde 2013 foram inauguradas 11 novas escolas, porém dentro da rede, existem unidades que são centenárias como a Etec Carlos de Campos inaugurada em 1911, outro exemplo é a Etec Lauro Gomes criada em 1957, todas existentes antes da formação do CPS e foram incorporadas na década de 90. 
Dados do vestibulinho de 2016 informam quem são os alunos ingressantes nesse período nas Etecs.

Gráfico 3 - Idade dos alunos ingressantes - 2016

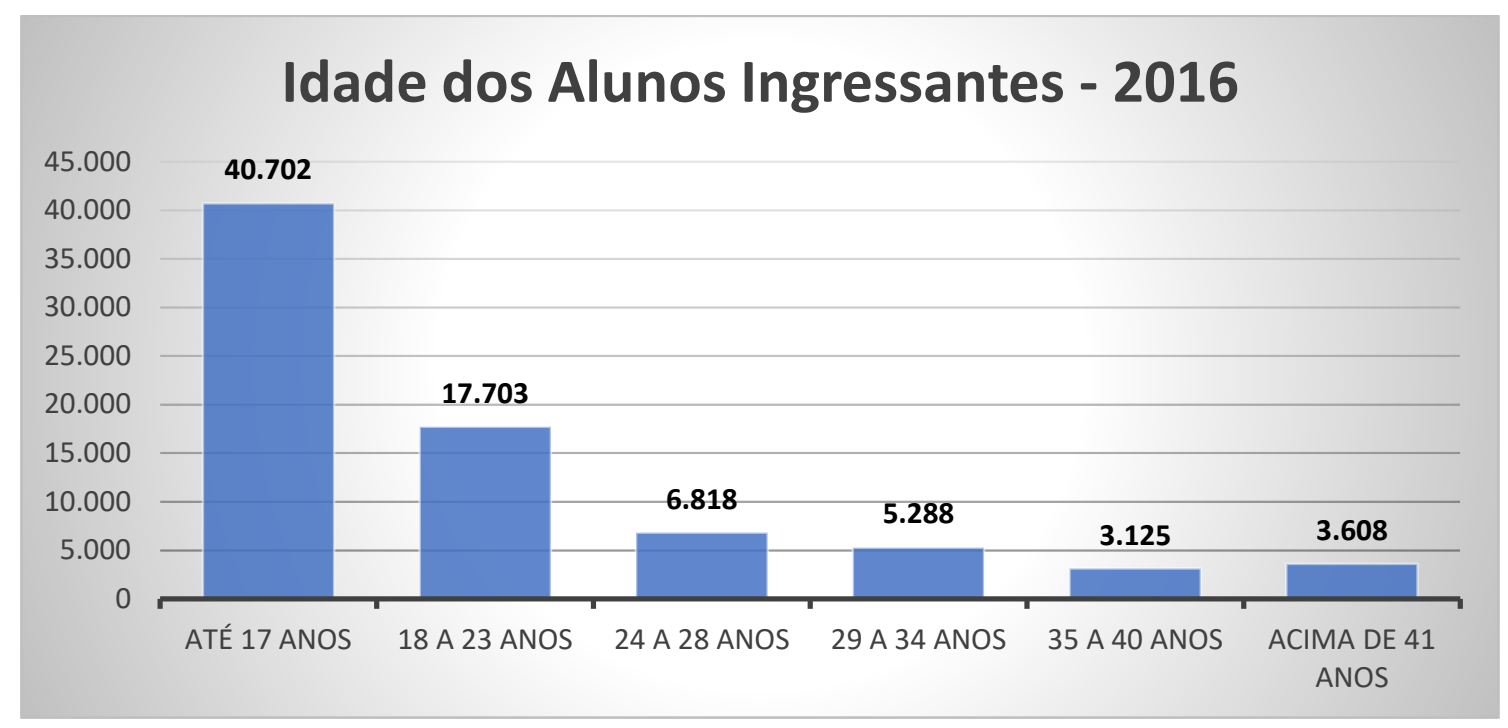

Fonte: Autora.

Metade dos alunos ingressantes (52\%) tem até 17 anos, eles estão em sua maioria nos cursos oferecidos do ensino médio regular ou no ensino médio integrado ao técnico, porém, o que precisa ser observado no gráfico 3 é a variedade das faixas etárias existentes correspondentes ao ensino médio/técnico, sendo possível, encontrar em uma sala de aula alunos que contemplam todas as idades demonstradas nesta pesquisa. Essa realidade no ambiente escolar é mais comum do que se imagina, sendo um desafio para professores no processo de ensino e aprendizagem. 


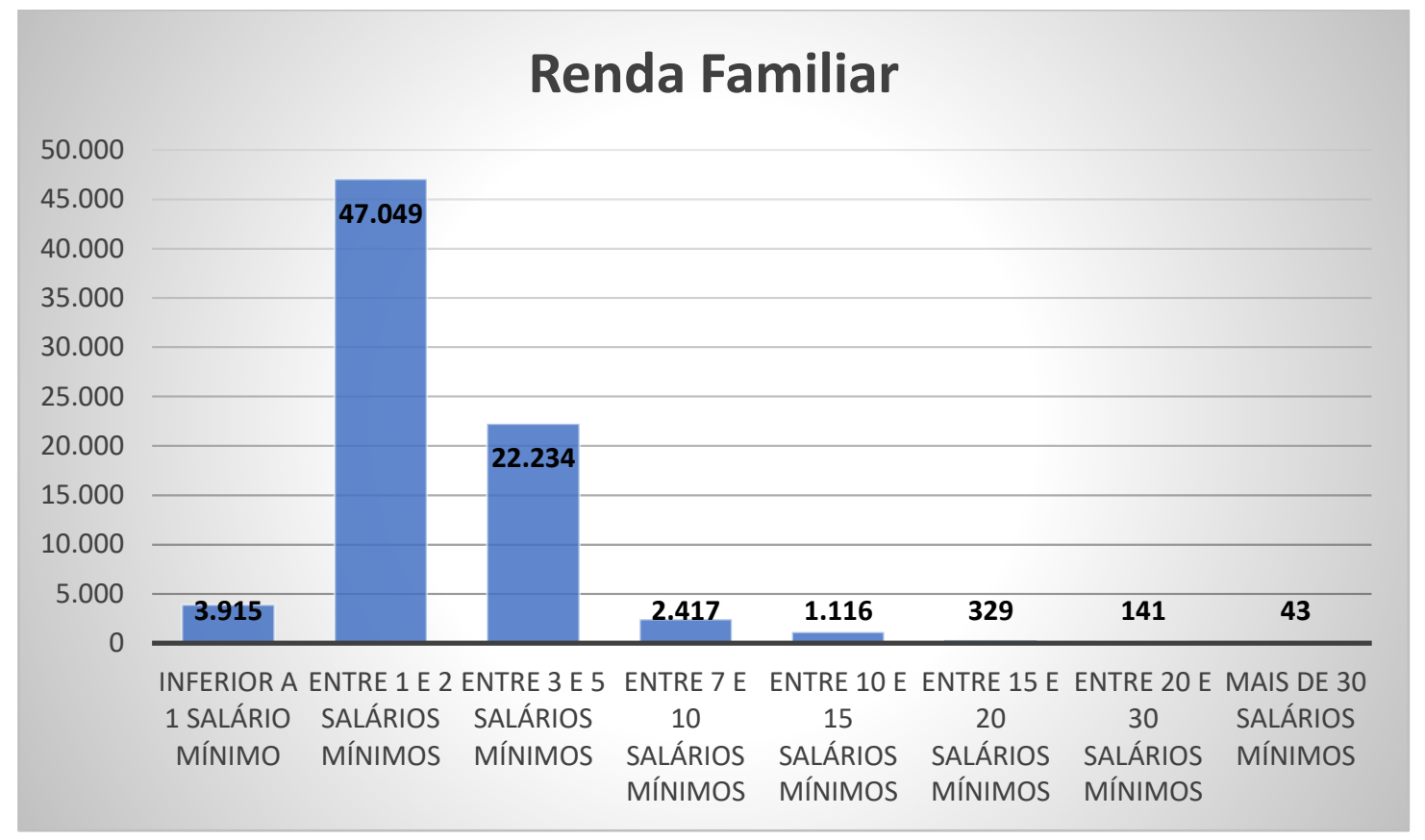

Fonte: Autora.

Outra realidade encontrada no ambiente escolar e que torna essa realidade diversificada é a renda familiar do aluno, essa variável está interligada a região demográfica onde a Etec está situada. Cerca de $66 \%$ dos alunos declararam renda familiar até 2 salários mínimos, muitos desses têm como objetivo ao procurar o curso técnico uma oportunidade de emprego, por outro lado, os $34 \%$ dos alunos que correspondem a rendas maiores, provavelmente terão objetivos diferenciados.

Com isso, ao discutir sobre o ambiente escolar nas Etecs não se pode referenciar como um ambiente único e padronizado, cada escola tem uma realidade conforme as diversas variáveis apresentadas e esta pesquisa trabalha em uma amostra que possa representar esse universo.

Hoje, o CPS é a maior instituição pública de ensino profissional da América Latina, os motivos para esse crescimento na última década foram por meio de um plano de expansão (classes descentralizadas e novas Etecs) com parcerias e um trabalho estratégico em atenção a aspectos importantes como índice populacional, percentual de jovens com ensino médio concluído, vocação regional e referências que orientam o crescimento sustentável da instituição (SOUZA, 2015).

As classes descentralizadas têm o intuito de fazer com que o ensino das Etecs possa acontecer em lugares que não comportam uma estrutura física escolar convencional, ou seja, 
nesse regime de classes descentralizadas em parcerias, em vez de construir uma nova escola técnica, criam-se turmas aproveitando a infraestrutura já existente. As criações das classes estão amparadas pela Deliberação CEE no 06/99 que autoriza sua instalação, para atender a um projeto educacional com justificativa social e atendimento a uma demanda específica ou transitória, visando à oferta de educação profissional de nível técnico. Nos últimos anos, por meio desse projeto e convênios com a Secretaria da Educação do Estado e as prefeituras, permitiram ao Centro Paula Souza expandir o número de vagas em salas de escolas estaduais, como também a utilização de Centros Educacionais Unificados (CEUs) e outras estruturas disponibilizadas pelos parceiros (SOUZA, 2015; ZANIRATO, 2017).

Os cursos são supervisionados por uma Etec próxima a classe descentralizada, cabe ao Centro Paula Souza o dever de disponibilizar docentes, realizar Vestibulinho, matrícula de alunos e acompanhamento da vida escolar, bem como prover a estrutura pedagógica e supervisão, o parceiro por sua vez estará incumbido de proporcionar as instalações físicas necessárias para o desenvolvimento do curso, de acordo com, o que foi acordado pelo convênio firmado entre ambos (SOUZA, 2015; ZANIRATO, 2017).

Pelos últimos dados, referente ao $2^{\circ}$ semestre de 2017, o total de alunos distribuídos em todos os 12 eixos tecnológicos era cerca de 207.507. O eixo que mais concentra alunos é o de Gestão e Negócios, cerca de 36\% do total. Nesse eixo está o curso Técnico em Administração que representa 56\% do total de alunos. O curso técnico em Administração é ofertado a partir de 5 modalidades: técnico, EJA (Educação de Jovens e Adultos), Ead Online e ETIM (Ensino Técnico Integrado ao Médio). Esse curso participou da amostra desta pesquisa e serviu como base de comparação em relação a outros cursos. 
Gráfico 5 - Quantidade de alunos - Técnico em Administração

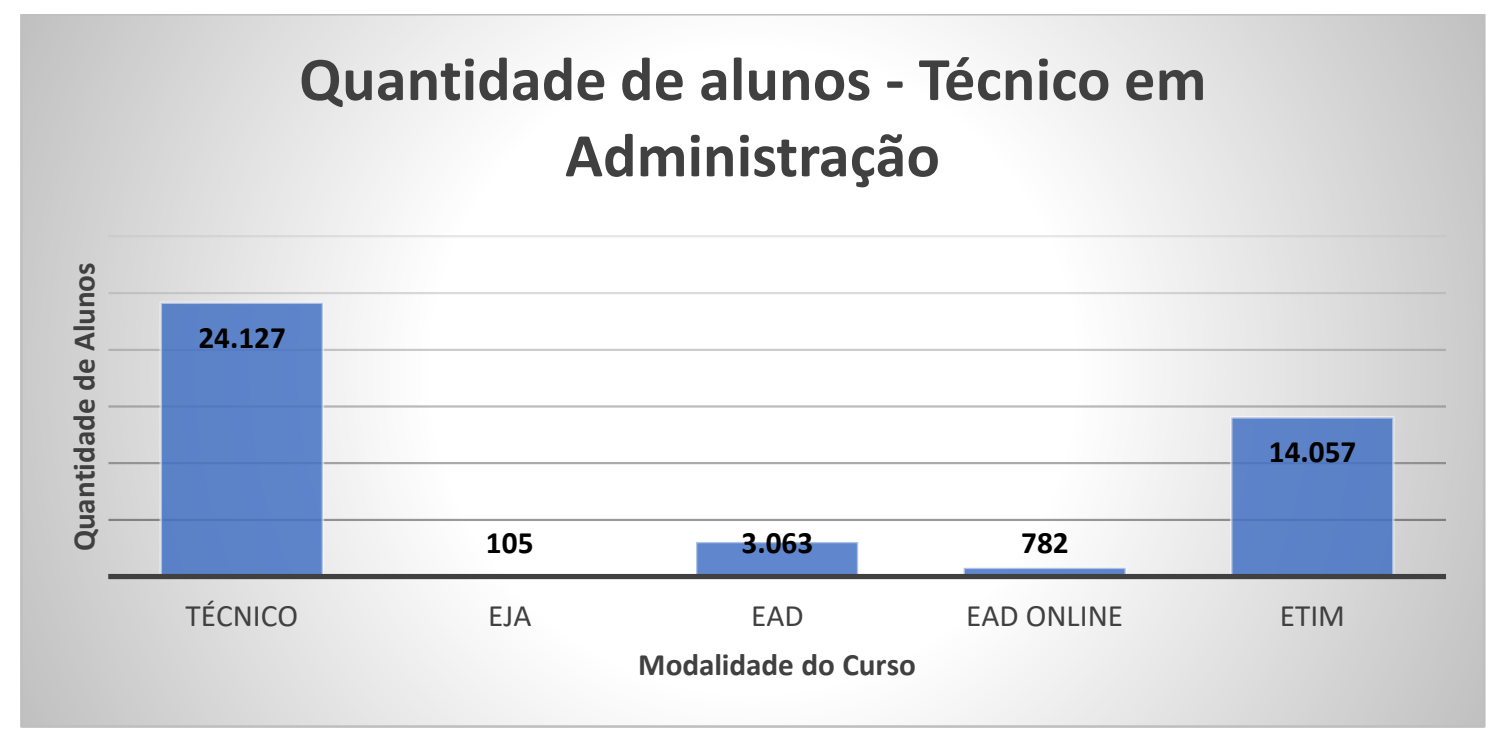

Fonte: Autora.

O ensino do empreendedorismo e o CPS estão intimamente ligados, um dos objetivos estratégicos da instituição é promover a cultura de inovação e empreendedorismo em suas escolas e para isso ações, parceiras e convênios são realizados, um exemplo disso foi a criação da Agência Inova São Paulo em 2010, com objetivo de promover a cultura de inovação e empreendedorismo por meio de atividades empreendedoras e de inovação a partir da colaboração de empresas tanto no setor público quanto privado, a fim de criar oportunidades que contribuam para o desenvolvimento social e econômico. São 4 as áreas de atuação da agência: propriedade intelectual; prospecção tecnológica; inteligência competitiva; e empreendedorismo e startups (SOUZA, 2015, 2017a).

Uma ação realizada pela Agência Inova Paula Souza é o Desafio Inova, uma competição a qual os alunos criam novos modelos de negócios voltados tanto para produtos como serviços, ou seja, fazendo com que o aluno na prática crie competências empreendedoras. As melhores ideias são auxiliadas por incubadoras de negócios, após finalização, os alunos apresentam os projetos em feiras para potenciais investidores (SOUZA, 2015, 2017a).

Assim como dito, práticas de ensino e aprendizagem que envolvem atividades executadas fora da sala de aula, podem ajudar a fomentar o empreendedorismo.

Experiências que envolvem o empreendedorismo a partir de programas vinculados a escolas de ensino médio, oferecem aos alunos uma ferramenta para suscitar atitudes e competências empreendedoras (LEPOUTRE et al., 2010). 
Outra iniciativa é a Escola de Inovadores, que tem como objetivo fornecer formação gratuita que ajudam a amadurecer as ideias em startups. Além dos alunos, os professores do CPS também podem receber essa formação, eles passam pelo processo de criação de um negócio e participam de palestras, oficinas e seminários relacionados ao empreendedorismo (SOUZA, 2015, 2017a).

Quando a educação do empreendedorismo é conduzida em um ambiente de apoio, ela aumentará o interesse dos estudantes pelo assunto como também a sua preparação. Além disso, os currículos para essa educação devem incorporar uma base sólida para a aprendizagem e se possível, devem ajudar na motivação de seus jovens a se engajarem (DYER, 1995; KOURILSKY; WALSTAD, 1998).

Para a continuação do fomento do empreendedorismo, o CPS realiza diversas parcerias, uma delas foi com a empresa Google com a competição Startup in School, a qual, o objetivo era a criação de aplicativos voltados a melhoria da qualidade de vida das pessoas. Incialmente, foram 90 projetos inscritos, dentre esses, 10 foram escolhidos por uma banca de especialistas para receberem capacitação na criação de novos produtos, além disso, as três melhores ideias ganharam um programa de mentoria de três meses e a participação no Day Camp realizado na Google Campus, em São Paulo. Outras parcerias visando o fomento do empreendedorismo estão sendo realizadas com outras empresas como a Telefônica Vivo, a Fundação Lemmann e o programa Technovation de desenvolvimento tecnológico para meninas da Junior Achievment. Além dessas parcerias, o CPS firmou outras colaborações com empresas como Santander, Itaú Unibanco, Embraer, SPTrans, Carrefour, Motorola, Instituto Campus Party, CPFL, Universidade São Judas Tadeu e Fundação Volkswagen (SOUZA, 2017a).

Em instituições que promovem o ensino do empreendedorismo, é possível identificar jovens com inclinações empreendedoras. Pesquisas realizadas demonstram que o adolescente que tem contato com o empreendedorismo na sua formação em nível médio, pensa em se tornar dono de seu próprio negócio. Principalmente, quando a escola incentiva atividades extraclasse que envolvem a estimulação de características cognitivas como: o trabalho em equipe, assumir riscos, responsabilidade e comprometimento, os jovens assumem esses atributos e com essas experiências são mais propensos a uma ação positiva para se envolverem com empreendedorismo (BONNETT; FURNHAM, 1991; HICKIE, 2011). Esta dissertação segue essa linha de pesquisa, mensurando como as Etecs podem influenciar os estudantes na intenção de empreender, ou seja, no intuito de abrir futuramente seu próprio negócio. 
Outra demonstração de ações da instituição voltada ao empreendedorismo foi a criação de uma Fatec e Etec em cooperação com o Serviço Brasileiro de Apoio às Micro e Pequenas Empresas (SEBRAE - SP) (SOUZA, 2015).

Além disso, outro ponto a ser considerado importante no ensino do empreendedorismo é a maneira como a instituição atua em sala de aula. O CPS atua a partir de práticas pedagógicas contemporâneas, visando despertar nos alunos competências atitudinais, ou seja, permitindo que o aluno seja o protagonista do seu aprendizado, o tornando mais crítico ao analisar as informações e tomar decisões. O uso de metodologias ativas realizadas por meio de projetos e da resolução de casos reais dentro da sala de aula, proporciona aos alunos não só adquirir o aprendizado pela teoria, mas sim pela prática. Exemplo dessas metodologias é a Feira Tecnológica do Centro Paula Souza - FETEPS - organizada há mais de 10 anos, com mais de 4,2 mil projetos inscritos não só das Fatecs e Etecs, bem como, outras instituições de ensino latino-americanas. O objetivo da FETEPS é evidenciar como os alunos efetivamente aprendem a transformar o seu aprendizado de sala de aula em ideias viáveis que ajudem a sociedade, essa Feira Tecnológica acaba sendo uma vitrine para outros eventos e possíveis investidores (SOUZA, 2017a).

Para que na sala de aula haja todo esse comportamento, os professores devem estar em constante atualização. O CETEC é um departamento dentro da estrutura do CPS que é responsável pela formação continuada para professores e servidores. As capacitações são feitas para atender a demanda de todos os eixos tecnológicos, quando há necessidade, existem capacitações especiais para que os professores possam dar suporte aos alunos nessas atividades específicas (SOUZA, 2015, 2017a).

A literatura descreve a importância e o papel do professor no processo de ensino e aprendizagem, e o quanto ele precisa estar em consonância com o que irá ensinar em sala de aula. O professor precisa dominar o conteúdo e as práticas metodológicas ideais para que o processo de ensino e aprendizagem ocorra com eficiência. O CPS entende a importância de capacitar e atualizar seus professores, isso é evidente, pois a instituição tem um departamento específico para cuidar dessa questão.

A inclusão de noções de empreendedorismo no currículo dos cursos da rede de ensino (CPS) veio complementar esse movimento, incentivando a capacidade do estudante de idealizar, coordenar e realizar projetos e negócios próprios ou dentro de empresas. (SOUZA, 2017b, 2017c). 
Gráfico 6 - Relação de cursos com e sem disciplinas de Empreendedorismo

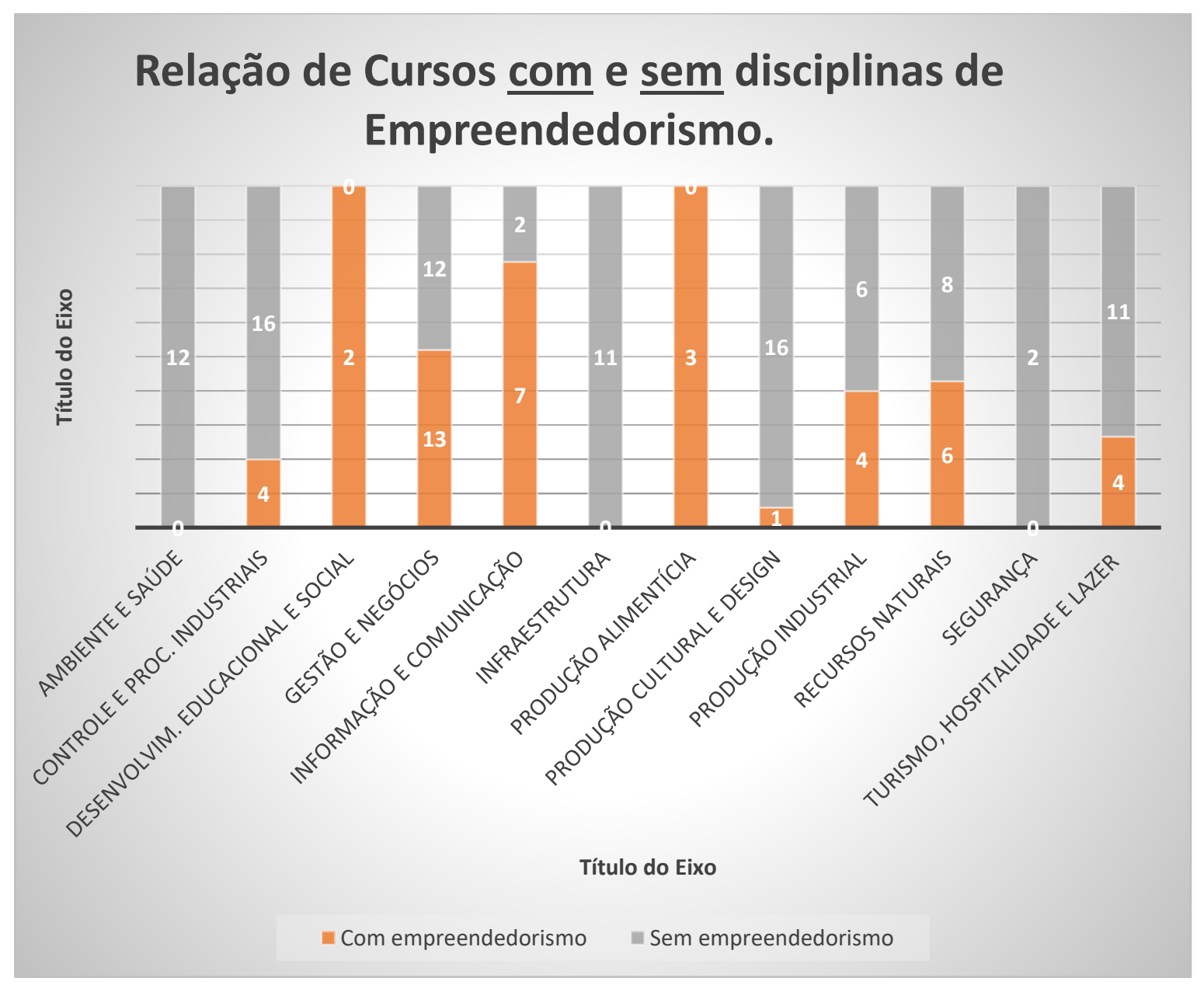

Fonte: Autora

Dos cursos realizados em 2017, 44 têm em sua grade curricular disciplinas que contemplem o assunto do empreendedorismo, ou seja, cerca de $31 \%$ dos cursos das Etecs têm uma disciplina específica sobre empreendedorismo.

Os cursos que são voltados ao ensino do empreendedorismo, possibilitam aos alunos experiência e conhecimentos práticos em habilidades como: geração de ideias, pesquisa de mercado, comunicação, negociação, gerenciamento de conflitos, desenvolvimento de produtos e processos, capacidade de inovar, proporcionar liderança, dentre outras características, manifestando assim, interesse e potencial de iniciar um novo negócio (BIRDTHISTLE; HYNES; FLEMING, 2007; FAOITE et al., 2003).

Com todo esse perfil o CPS tem uma preocupação com o currículo escolar. Na intenção de cada vez mais estar atualizado com a realidade do mercado, foi instituído um departamento em 1999 que tem como objetivo a criação e atualização constante do currículo escolar, esse 
departamento é o Grupo de Formulação e Análises Curriculares (Gfac) (ARAÚJO; DEMAI; PRATA, 2017).

Um dos pontos discutidos no Gfac desde 2014 é o fortalecimento das competências relativas ao empreendedorismo, atualmente dos cursos existentes, aproximadamente 50\% abordam o tema empreendedorismo, embora em alguns cursos o empreendedorismo apareça em forma de componente curricular, todos os cursos se propõem a trabalhar competências empreendedoras. Essas competências são desenvolvidas transversalmente em componentes específicos dos cursos ou a partir da interdisciplinaridade, que contribuem para o desenvolvimento do perfil empreendedor e na formação do profissional contemporâneo (ARAÚJO; DEMAI; PRATA, 2017).

Os autores Boyle (2012), Cheung e Au (2010) e Ruskovaara et al. (2010), apontam a significância de ter uma disciplina que aborde o empreendedorismo no currículo escolar e o CPS além de ter essa consciência, também, tem o interesse e a preocupação em atualizar os currículos conforme as mudanças existentes na sociedade em geral.

Como visto na literatura acadêmica, esses tipos de metodologias que envolvem o aluno a ter uma experiência real com o empreendedorismo, podem facilitar o processo de ensino e aprendizagem e assim despertar a intenção de empreender, o CPS é uma instituição favorável para realização deste trabalho, pois propicia essas práticas a seus alunos, além disso, o ambiente escolar é constituído pela diversidade de realidades encontradas em cada Etec, e esse será o contexto no qual a pesquisa será aplicada.

Visto isso, esta pesquisa se propõe a testar também se o ambiente escolar influencia positivamente a intenção empreendedora dos alunos.

Possuindo como foco de estudo o curso técnico em Administração, a pesquisa também se dispõe a testar se a variável curso desperta alguma diferença entre os relacionamentos de todas as variáveis latentes.

Quadro 2 - Hipóteses do Estudo - Parte 2

(continua)

\begin{tabular}{|l|l|}
\hline Hipóteses & $\begin{array}{l}\text { Descrição } \\
\text { O ambiente escolar influencia positivamente a intenção empreendedora. }\end{array}$ \\
\hline H7 & $\begin{array}{l}\text { Existe diferença entre as relações de sociabilidade e autoeficácia no que diz } \\
\text { respeito ao curso. }\end{array}$ \\
\hline H8a & $\begin{array}{l}\text { Existe diferença entre as relações de planejamento e autoeficácia no que diz } \\
\text { respeito ao curso. }\end{array}$ \\
\hline
\end{tabular}


(conclusão)

\begin{tabular}{|l|l|}
\hline Hipóteses & $\begin{array}{l}\text { Descrição } \\
\text { H8c }\end{array}$ \\
$\begin{array}{l}\text { Existe diferença entre as relações de liderança e autoeficácia no que diz respeito } \\
\text { ao curso. }\end{array}$ \\
\hline H8d & $\begin{array}{l}\text { Existe diferença entre as relações de inovação calculados e autoeficácia no que } \\
\text { diz respeito ao curso. }\end{array}$ \\
\hline H8e & $\begin{array}{l}\text { Existe diferença entre as relações de assumir riscos calculados e autoeficácia no } \\
\text { que diz respeito ao curso. }\end{array}$ \\
\hline H8f & $\begin{array}{l}\text { Existe diferença entre as relações de autoeficácia e intenção empreendedora no } \\
\text { que diz respeito ao curso. } \\
\text { Existe diferença entre as relações de ambiente escolar e intenção } \\
\text { empreendedora no que diz respeito ao curso. }\end{array}$ \\
\hline H8g &
\end{tabular}

Fonte: Autora

O modelo estrutural no qual será testado todas as hipóteses será o seguinte:

Figura 1 - Modelo Estrutural

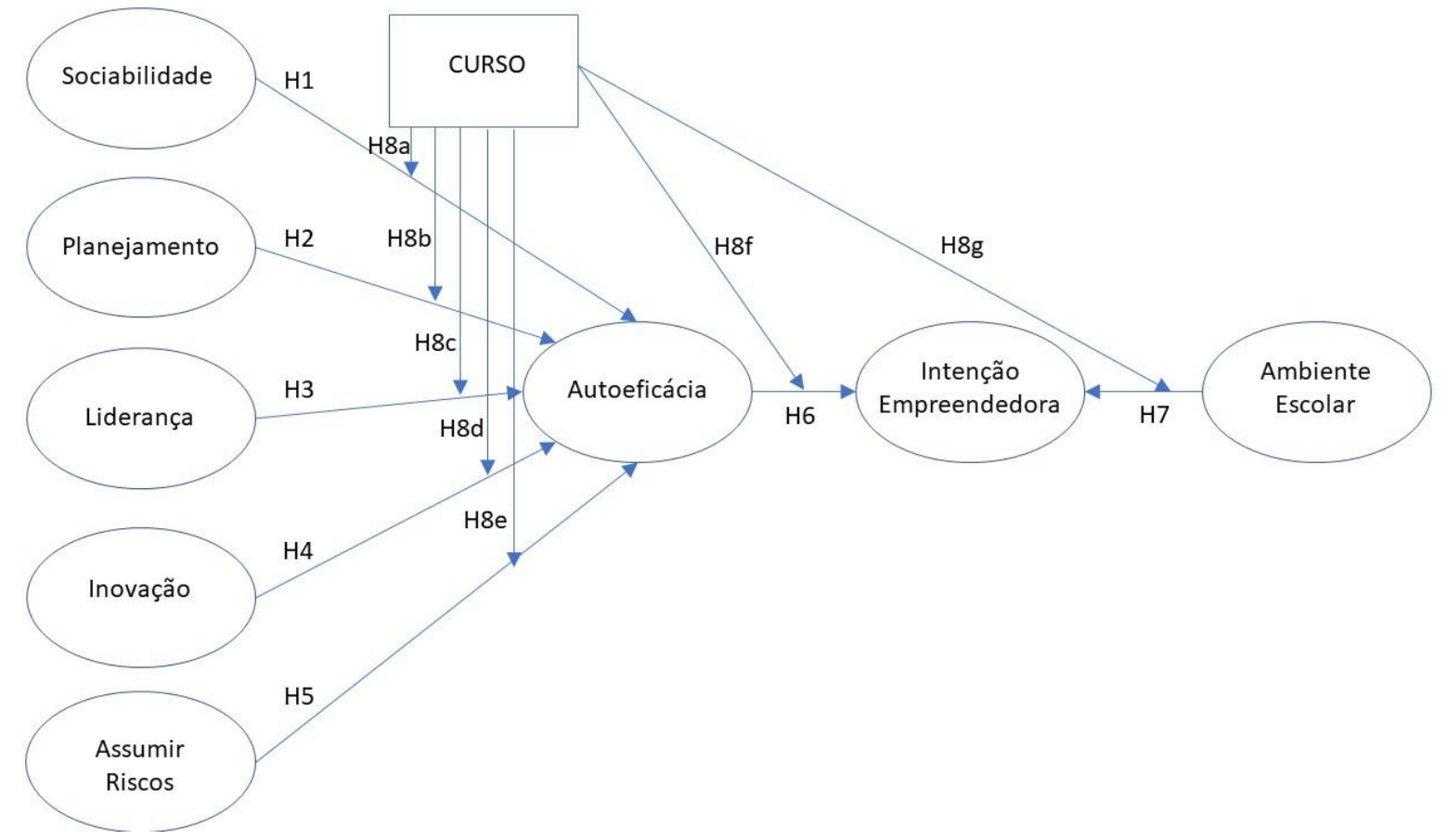

Fonte: Autora “adaptado de” Moraes, Iizuka e Pedro, 2018. 


\section{METODOLOGIA}

A pesquisa será desenvolvida por meio de metodologia quantitativa, com o uso da análise multivariada de dados. Será estudado apenas uma amostra dessa população, e a partir dos resultados o pesquisador pode realizar inferências sobre a população (CRESWELL; LOPES, 2010; HAIR et al., 2009).

\subsection{ESCALA E QUESTIONÁRIO}

O questionário e o modelo foram criados para pesquisas que envolvem estudantes do ensino superior. Esse instrumento foi utilizado incialmente para analisar o potencial e perfil empreendedor de estudantes do curso de graduação de Administração (IIZUKA; MORAES, 2014). Em seguida para analisar o potencial e perfil empreendedor dos empresários juniores de Administração no Brasil (DIAFÉRIA; IIZUKA, 2016). E por fim, para investigar os efeitos das características empreendedoras e do ambiente universitário na intenção empreendedora do estudante de nível superior (MORAES; IIZUKA; PEDRO, 2018). O público desta pesquisa se diferencia, pois, o nível de ensino não é o mesmo, diante disso, observou-se a necessidade de adaptação do instrumento. A adaptação da escala e do questionário se deu em 4 etapas:

a) Primeira etapa: alteração na linguagem do questionário.

b) Segunda etapa: mudanças no construto de autoeficácia e ambiente escolar.

c) Terceira etapa: sugestão da pesquisadora no construto de autoeficácia.

d) Quarta etapa: entrevista com professores especialistas e pré-teste.

\subsubsection{Primeira etapa: alteração da linguagem do questionário.}

A primeira adaptação aconteceu pela convivência diária com os estudantes do ensino médio. Houve a percepção que a linguagem do questionário estaria muito requintada e formal para o entendimento do público, levou-se essa questão aos autores do instrumento, e com uma proposta de mudança de linguagem para uma análise crítica.

Algumas modificações foram sugeridas em relação a linguagem, no quadro 5 é possível verificar o instrumento completo com as alterações realizadas. 


\subsubsection{Segunda etapa: mudanças no construto de autoeficácia e ambiente.}

Os autores analisaram e houve uma sugestão de mudança no construto de autoeficácia baseados no artigo Saeed et al. (2015), pois as questões desse artigo poderiam estar mais adequadas que as anteriormente.

Outro construto que houve mudanças significativas foi o do ambiente escolar, foi sugerido pelos autores uma mudança na estrutura de todas as questões do bloco e a inserção de mais 3 questões.

Após receber o feedback foi encontrado pela pesquisadora um outro artigo dos autores Top, Çolakoğlu e Dilek (2012), eles realizaram uma pesquisa para identificar as opiniões dos alunos do ensino médio profissional referente ao empreendedorismo a partir da autoeficácia. Mediante a isso, a sugestão enviada para os autores foi a seguinte.

Quadro 3 - Segunda adaptação do instrumento

\begin{tabular}{|c|c|c|}
\hline \multicolumn{3}{|c|}{ VERSÃO ALTERADA } \\
\hline Ind. & Questão & Referência \\
\hline $\bar{\alpha}$ & $\begin{array}{l}\text { Se eu tiver oportunidades de crédito limitadas, procurarei } \\
\text { um amigo para ajudar-me. }\end{array}$ & Top, Çolakoğlu e Dilek,(2012) \\
\hline$\stackrel{N}{\ddots}$ & $\begin{array}{l}\text { Sei que posso contar com a grande maioria das pessoas } \\
\text { que me relaciono, caso precise de ajuda. }\end{array}$ & $\begin{array}{l}\text { Adaptado de Moraes, lizuka e } \\
\text { Pedro (2018). } \\
\text { Adaptado de Top, Çolakoğlu e } \\
\text { Dilek (2012) }\end{array}$ \\
\hline 妊 & $\begin{array}{l}\text { Sempre que possível, gosto de diversificar o jeito de } \\
\text { realizar minhas atividades. }\end{array}$ & $\begin{array}{l}\text { Adaptado de Moraes, Iizuka e } \\
\text { Pedro (2018). }\end{array}$ \\
\hline 朰 & $\begin{array}{l}\text { Quando me dão uma atividade tradicional a ser realizada, } \\
\text { gosto de elaborar novas maneiras para realizá-las. }\end{array}$ & $\begin{array}{l}\text { Adaptado de Moraes, lizuka e } \\
\text { Pedro (2018). }\end{array}$ \\
\hline \multirow{2}{*}{$\bar{\sum}$} & $\begin{array}{l}\text { O ambiente escolar me auxiliou a detectar oportunidades } \\
\text { de negócio. }\end{array}$ & \multirow{6}{*}{$\begin{array}{l}\text { Sugestões dos responsáveis pela } \\
\text { escala original para o construto } \\
\text { de ambiente escolar. }\end{array}$} \\
\hline & O ambiente escolar me auxiliou a ser persistente. & \\
\hline$\sum_{i}^{N}$ & $\begin{array}{l}\text { O ambiente escolar aprimorou minha habilidade de } \\
\text { liderança. }\end{array}$ & \\
\hline \multirow{2}{*}{$\sum_{i}^{\infty}$} & $\begin{array}{l}\text { O ambiente escolar aprimorou minha capacidade de } \\
\text { planejar. }\end{array}$ & \\
\hline & O ambiente escolar aprimorou minha criatividade. & \\
\hline$\stackrel{+}{\oplus}$ & $\begin{array}{l}\text { O ambiente escolar aprimorou minha capacidade de } \\
\text { inovar. }\end{array}$ & \\
\hline
\end{tabular}


(conclusão)

\begin{tabular}{|c|c|c|}
\hline$\sum_{i}^{n}$ & $\begin{array}{l}\text { O ambiente escolar me ensinou a tomar decisões quando } \\
\text { enfrento um problema, aprimorando minha habilidade de } \\
\text { assumir riscos calculados. }\end{array}$ & \\
\hline$\hat{\sum}$ & $\begin{array}{l}\mathrm{O} \text { ambiente escolar me motivou a querer abrir meu } \\
\text { próprio negócio no futuro. }\end{array}$ & \\
\hline$\sum_{\substack{\ell \\
\&}}^{\infty}$ & $\begin{array}{l}\text { As atividades em feiras (FETEPS), eventos e workshops } \\
\text { me proporcionaram diversos contatos importantes } \\
\text { pessoal e profissionalmente. }\end{array}$ & Sugestão da pesquisadora. \\
\hline
\end{tabular}

Fonte: Autora

Após análise, a questão sugerida para AR1 baseada nos autores Top, Çolakoğlu e Dilek (2012) não estaria dentro dos parâmetros exatos para medir o construto de autoeficácia, sendo assim foi decidido manter a questão original.

\subsubsection{Terceira etapa: sugestão da pesquisadora no construto de autoeficácia}

Após a análise os autores sugeriram a leitura do artigo do autor Noble et al. (2000) para aprimorar o construto de autoeficácia. Ao analisar o artigo o construto ficou com as seguintes questões:

Quadro 4 - Terceira adaptação do instrumento

(continua)

\begin{tabular}{|c|c|c|c|}
\hline & VERSÃO ORIGINAL & REFERÊNCIAS & VERSÃO ALTERADA \\
\hline $\bar{\tau}$ & $\begin{array}{l}\text { Eu acho que tenho habilidades para } \\
\text { detectar oportunidades de negócios } \\
\text { no mercado. }\end{array}$ & \multirow{3}{*}{$\begin{array}{l}\text { Rocha e Freitas } \\
(2014)\end{array}$} & $\begin{array}{l}\text { Creio que tenho habilidade em identificar } \\
\text { boas oportunidades no ambiente no qual } \\
\text { estou inserido. }\end{array}$ \\
\hline $\begin{array}{l}m \\
\text { II } \\
\frac{1}{4}\end{array}$ & $\begin{array}{l}\text { Profissionalmente, considero-me } \\
\text { muito mais persistente do que os } \\
\text { outros. }\end{array}$ & & $\begin{array}{l}\text { Comparando com as outras pessoas que } \\
\text { convivem comigo, creio que sou uma pessoa } \\
\text { muito mais persistente que as demais. }\end{array}$ \\
\hline 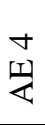 & $\begin{array}{l}\text { Eu sempre encontro soluções } \\
\text { criativas aos problemas em que me } \\
\text { deparo }\end{array}$ & & NÃO HOUVE ALTERAÇÃO \\
\hline 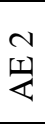 & $\begin{array}{l}\text { Eu executo minhas tarefas } \\
\text { corretamente, respeitando os prazos } \\
\text { estabelecidos }\end{array}$ & $\begin{array}{l}\text { Desenvolvido } \\
\text { pelos autores }\end{array}$ & NÃO HOUVE ALTERAÇÃO \\
\hline $\begin{array}{l}n \\
\text { 岁 }\end{array}$ & & & $\begin{array}{l}\text { Posso trabalhar de forma produtiva sob } \\
\text { estresse contínuo, pressão e conflito }\end{array}$ \\
\hline 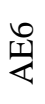 & & & $\begin{array}{l}\text { Eu posso desenvolver e manter relações } \\
\text { favoráveis com potenciais investidores }\end{array}$ \\
\hline 茫 & & & $\begin{array}{l}\text { Posso ver novas oportunidades de mercado } \\
\text { para novos produtos e serviços }\end{array}$ \\
\hline
\end{tabular}


(conclusão)

\begin{tabular}{|c|c|c|}
\hline VERSÃO ORIGINAL & REFERÊNCIAS & VERSÃO ALTERADA \\
\hline $\begin{array}{l}\infty \\
\text { T⿱宀⿻三丨口 }\end{array}$ & \multirow{2}{*}{$\begin{array}{l}\text { Noble et al } \\
(2000)\end{array}$} & $\begin{array}{l}\text { Eu posso recrutar e treinar funcionários } \\
\text { chave }\end{array}$ \\
\hline 产 & & $\begin{array}{l}\text { Posso desenvolver um ambiente de trabalho } \\
\text { que incentive as pessoas a experimentar algo } \\
\text { novo }\end{array}$ \\
\hline
\end{tabular}

Fonte: Autora.

\subsubsection{Quarta etapa: entrevista com professores especialistas e pré-teste.}

Para finalizar a escala completa, foi consultado 2 professores da Etec que ministram a aula de empreendedorismo para verificar o instrumento, o resultado foi positivo, os professores afirmaram que as questões estavam em uma estrutura no qual os estudantes teriam entendimento sobre o questionário. $\mathrm{O}$ instrumento apresentado para apreciação dos professores e posteriormente enviado para os autores foi o seguinte:

Quadro 5 - Finalização do instrumento

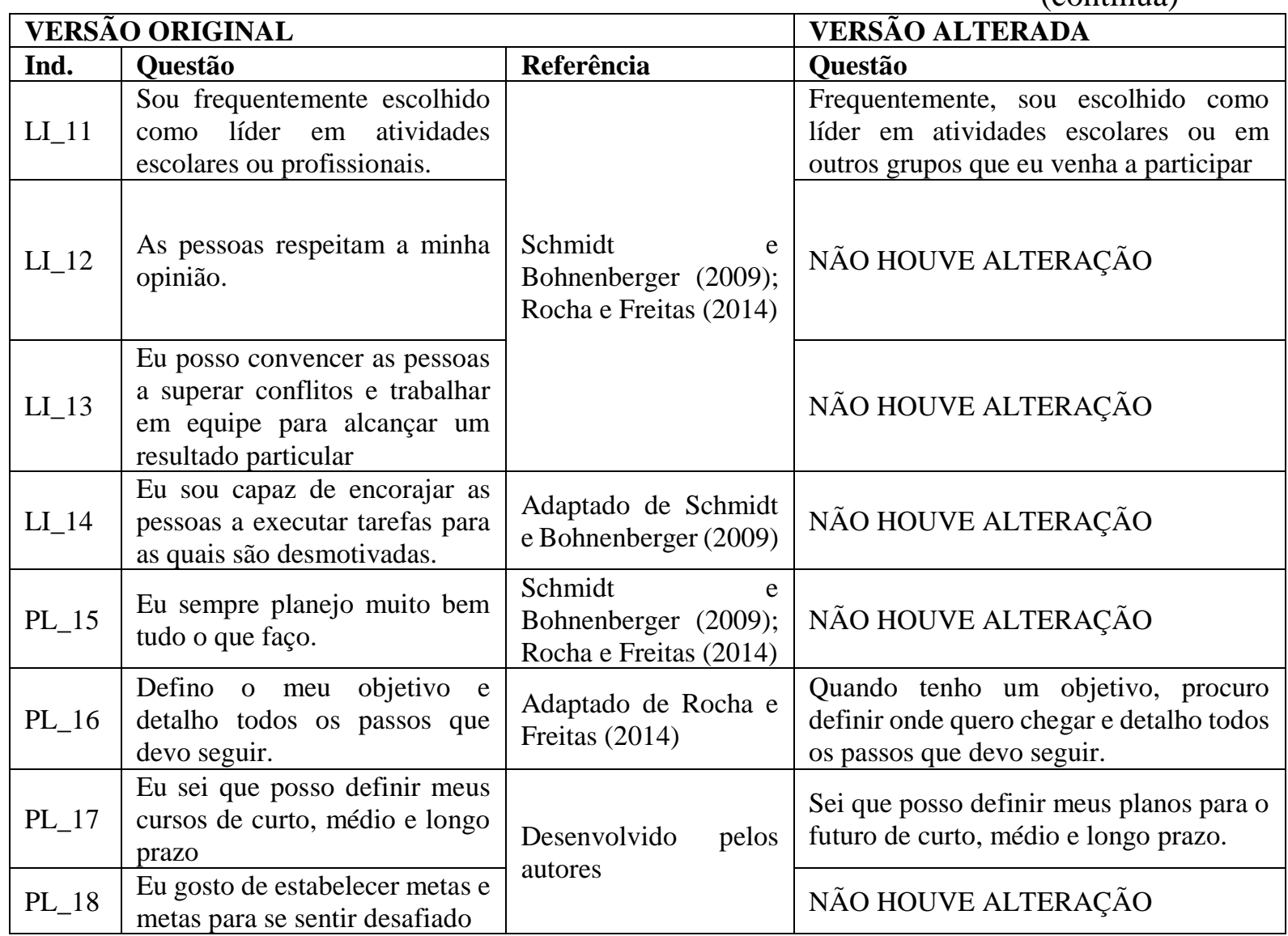




\begin{tabular}{|c|c|c|c|}
\hline \multicolumn{3}{|c|}{ VERSÃO ORIGINAL } & \multirow{2}{*}{$\begin{array}{l}\text { VERSÃO ALTERADA } \\
\text { Questão }\end{array}$} \\
\hline Ind. & Questão & Referência & \\
\hline IN_19 & $\begin{array}{l}\text { Prefiro um trabalho cheio de } \\
\text { novidades, a uma atividade } \\
\text { rotineira }\end{array}$ & \multirow{2}{*}{$\begin{array}{l}\text { Schmidt e } \\
\text { Bohnenberger (2009); } \\
\text { Rocha e Freitas (2014) }\end{array}$} & NÃO HOUVE ALTERAÇÃO \\
\hline IN_20 & $\begin{array}{l}\text { Eu gosto de mudar minha } \\
\text { maneira de trabalhar sempre } \\
\text { que possível. }\end{array}$ & & NÃO HOUVE ALTERAÇÃO \\
\hline IN_21 & $\begin{array}{l}\text { Eu gosto de melhorar o modo } \\
\text { convencional e correto de } \\
\text { atividades, não seguindo } \\
\text { rigorosamente as etapas }\end{array}$ & \multirow{2}{*}{$\begin{array}{l}\text { Adaptado de Schmidt } \\
\text { e } \\
\text { Bohnenberger (2009) }\end{array}$} & NÃO HOUVE ALTERAÇÃO \\
\hline IN_22 & $\begin{array}{l}\text { Aposto na criatividade ao } \\
\text { elaborar projetos / atividades }\end{array}$ & & NÃO HOUVE ALTERAÇÃO \\
\hline AR_23 & $\begin{array}{l}\text { Eu assumiria uma dívida de } \\
\text { longo prazo, acreditando nas } \\
\text { vantagens que uma } \\
\text { oportunidade de negócio me } \\
\text { traria. }\end{array}$ & \multirow[t]{2}{*}{$\begin{array}{l}\text { Schmidt } \quad \text { e } \\
\text { Bohnenberger (2009); } \\
\text { Rocha e Freitas (2014) }\end{array}$} & NÃO HOUVE ALTERAÇÃO \\
\hline AR_24 & $\begin{array}{l}\text { Eu admito assumir riscos em } \\
\text { troca de possíveis benefícios }\end{array}$ & & $\begin{array}{l}\text { Aceito correr riscos em troca de possíveis } \\
\text { benefícios. }\end{array}$ \\
\hline AR_25 & $\begin{array}{l}\text { Minhas decisões não são } \\
\text { predominantemente baseadas } \\
\text { na minha zona de conforto }\end{array}$ & \multirow{2}{*}{$\begin{array}{l}\text { Desenvolvido pelos } \\
\text { autores }\end{array}$} & $\begin{array}{l}\text { Ao tomar decisões procuro me arriscar } \\
\text { mais ao ficar na minha zona de conforto. }\end{array}$ \\
\hline AR_26 & \begin{tabular}{llr}
\multicolumn{3}{l}{ Eu acredito que se envolver em } \\
situações de maior & risco \\
causará resultados & mais \\
impactantes & & \\
\end{tabular} & & $\begin{array}{l}\text { Acredito que se eu estiver disposto a } \\
\text { correr mais riscos, isso poderá me trazer } \\
\text { resultados mais interessantes. }\end{array}$ \\
\hline SO_27 & $\begin{array}{l}\text { Os contatos sociais que tenho } \\
\text { são muito importantes para } \\
\text { minha vida pessoal }\end{array}$ & \multirow{2}{*}{$\begin{array}{l}\text { Schmidt e } \\
\text { Bohnenberger (2009); } \\
\text { Rocha e Freitas (2014) }\end{array}$} & NÃO HOUVE ALTERAÇÃO \\
\hline SO_28 & $\begin{array}{l}\text { Conheço várias pessoas que } \\
\text { poderiam me ajudar } \\
\text { profissionalmente, } \\
\text { precisasse disso }\end{array}$ & & NÃO HOUVE ALTERAÇÃO \\
\hline SO_29 & $\begin{array}{l}\text { Eu me relaciono muito } \\
\text { facilmente com outras pessoas. }\end{array}$ & $\begin{array}{l}\text { Schmidt } \quad \text { e } \\
\text { Bohnenberger (2009); }\end{array}$ & NÃO HOUVE ALTERAÇÃO \\
\hline SO_30 & $\begin{array}{l}\text { Procuro manter } \text { contato } \\
\text { constante com pessoas da } \\
\text { minha rede }\end{array}$ & $\begin{array}{l}\text { Desenvolvido pelos } \\
\text { autores }\end{array}$ & NÃO HOUVE ALTERAÇÃO \\
\hline IE_31 & $\begin{array}{l}\text { Estou pronto para fazer o que } \\
\text { for preciso para ser um } \\
\text { empresário }\end{array}$ & Liñán e Chen (2009) & $\begin{array}{l}\text { Sinto que estou pronto para poder montar } \\
\text { o meu próprio negócio no futuro. }\end{array}$ \\
\hline IE_32 & $\begin{array}{l}\text { Embora eu trabalhe para outras } \\
\text { empresas, nunca abandonarei o } \\
\text { meu sonho de abrir meu } \\
\text { negócio }\end{array}$ & $\begin{array}{l}\text { Desenvolvido pelos } \\
\text { autores }\end{array}$ & $\begin{array}{l}\text { Mesmo que eu venha trabalhar para } \\
\text { outras empresas, nunca abandonarei meu } \\
\text { sonho de abrir meu negócio. }\end{array}$ \\
\hline IE_33 & $\begin{array}{l}\text { Minha maior conquista será ter } \\
\text { meu próprio negócio. }\end{array}$ & $\begin{array}{l}\text { Adaptado de Liñán e } \\
\text { Chen (2009) }\end{array}$ & NÃO HOUVE ALTERAÇÃO \\
\hline IE_34 & $\begin{array}{l}\text { Farei todos os esforços para } \\
\text { criar e manter minha própria } \\
\text { empresa. }\end{array}$ & $\begin{array}{l}\text { Adaptado de Saeed et } \\
\text { al. (2015); }\end{array}$ & $\begin{array}{l}\text { Farei de tudo para criar e manter meu } \\
\text { próprio negócio. }\end{array}$ \\
\hline IE_35 & $\begin{array}{l}\text { Pretendo começar um negócio } \\
\text { nos próximos anos }\end{array}$ & $\begin{array}{l}\text { Adaptado de Liñán e } \\
\text { Chen (2009) }\end{array}$ & $\begin{array}{l}\text { Tenho a intenção de abrir meu próprio } \\
\text { negócio no futuro }\end{array}$ \\
\hline
\end{tabular}


(continuação)

\begin{tabular}{|c|c|c|c|c|}
\hline \multicolumn{3}{|c|}{ VERSÃO ORIGINAL } & \multicolumn{2}{|c|}{ VERSÃO ALTERADA } \\
\hline Ind. & Questão & Referência & \multicolumn{2}{|l|}{ Questão } \\
\hline AE_36 & $\begin{array}{l}\text { Eu acho que tenho habilidades } \\
\text { para detectar oportunidades de } \\
\text { negócios no mercado. }\end{array}$ & \multirow{3}{*}{$\begin{array}{l}\text { Rocha e } \\
\text { Freitas } \\
(2014)\end{array}$} & \multicolumn{2}{|c|}{$\begin{array}{l}\text { Creio que tenho habilidade em identificar boas } \\
\text { oportunidades no ambiente no qual estou } \\
\text { inserido. }\end{array}$} \\
\hline AE_37 & $\begin{array}{l}\text { Profissionalmente, considero-me } \\
\text { muito mais persistente do que os } \\
\text { outros. }\end{array}$ & & \multicolumn{2}{|c|}{$\begin{array}{l}\text { Comparando com as outras pessoas que } \\
\text { convivem comigo, creio que sou uma pessoa } \\
\text { muito mais persistente que as demais. }\end{array}$} \\
\hline AE_38 & $\begin{array}{l}\text { Eu sempre encontro soluções } \\
\text { criativas aos problemas em que } \\
\text { me deparo }\end{array}$ & & \multicolumn{2}{|c|}{ NÃO HOUVE ALTERAÇÃO } \\
\hline AE_39 & $\begin{array}{l}\text { Eu executo minhas tarefas } \\
\text { corretamente, respeitando os } \\
\text { prazos estabelecidos }\end{array}$ & $\begin{array}{l}\text { Desenvolvido } \\
\text { pelos autores }\end{array}$ & \multicolumn{2}{|c|}{ NÃO HOUVE ALTERAÇÃO } \\
\hline \multirow{5}{*}{\multicolumn{2}{|c|}{ Adicionadas pelos autores }} & \multirow{5}{*}{$\begin{array}{l}\text { Noble et al } \\
(2000)\end{array}$} & AE_40 & $\begin{array}{l}\text { Posso trabalhar de forma produtiva } \\
\text { sob estresse contínuo, pressão e } \\
\text { conflito }\end{array}$ \\
\hline & & & AE_41 & $\begin{array}{l}\text { Eu posso desenvolver e manter } \\
\text { relações favoráveis com potenciais } \\
\text { investidores }\end{array}$ \\
\hline & & & AE_42 & $\begin{array}{l}\text { Posso ver novas oportunidades de } \\
\text { mercado para novos produtos e } \\
\text { serviços }\end{array}$ \\
\hline & & & AE_43 & $\begin{array}{l}\text { Eu posso recrutar e treinar } \\
\text { funcionários chave }\end{array}$ \\
\hline & & & AE_44 & $\begin{array}{l}\text { Posso desenvolver um ambiente de } \\
\text { trabalho que incentive as pessoas a } \\
\text { experimentar algo novo }\end{array}$ \\
\hline \multirow{2}{*}{\multicolumn{2}{|c|}{$\begin{array}{l}\text { O ambiente universitário me ajudou a } \\
\text { identificar oportunidades de negócios. }\end{array}$}} & \multirow{3}{*}{$\begin{array}{l}\text { Adaptado de } \\
\text { Fayolle e } \\
\text { Liñán (2014) } \\
\text { e Saeed et al. } \\
(2015)\end{array}$} & AM_45 & $\begin{array}{l}\text { O ambiente escolar me auxiliou a } \\
\text { detectar oportunidades de negócio. }\end{array}$ \\
\hline & & & AM_46 & $\begin{array}{l}\mathrm{O} \text { ambiente escolar me auxiliou a ser } \\
\text { persistente. }\end{array}$ \\
\hline \multicolumn{2}{|c|}{$\begin{array}{l}\text { O ambiente da Universidade me motivou a } \\
\text { querer abrir meu próprio negócio. }\end{array}$} & & AM_47 & $\begin{array}{l}\text { O ambiente escolar me motivou a } \\
\text { querer abrir meu próprio negócio no } \\
\text { futuro. }\end{array}$ \\
\hline \multicolumn{2}{|c|}{$\begin{array}{l}\text { O ambiente universitário desenvolveu } \\
\text { minhas habilidades de liderança a partir do } \\
\text { trabalho grupal. }\end{array}$} & \multirow{2}{*}{$\begin{array}{l}\text { Adaptado de } \\
\text { Schwarz et al. } \\
(2009) \quad \text { e } \\
\text { Fayolle e } \\
\text { Liñán }(2014)\end{array}$} & AM_48 & $\begin{array}{l}\text { O ambiente escolar aprimorou minha } \\
\text { habilidade de liderança. }\end{array}$ \\
\hline $\begin{array}{l}\mathrm{O} \text { ambi } \\
\text { minha c }\end{array}$ & $\begin{array}{l}\text { ente da Universidade aumentou } \\
\text { latividade e capacidade de inovar }\end{array}$ & & AM_49 & $\begin{array}{l}\text { O ambiente escolar aprimorou minha } \\
\text { capacidade de inovar. }\end{array}$ \\
\hline \multirow{2}{*}{\multicolumn{2}{|c|}{$\begin{array}{l}\text { O ambiente universitário me forneceu } \\
\text { tarefas de planejamento e estratégia em } \\
\text { diferentes disciplinas, desenvolvendo } \\
\text { minha capacidade de planejar. }\end{array}$}} & \multirow{3}{*}{$\begin{array}{l}\text { Desenvolvido } \\
\text { pelos autores } \\
\text { com } \\
\text { base } \\
\text { Fayolle em } \quad \& \\
\text { Liñán }(2014)\end{array}$} & AM_50 & $\begin{array}{l}\mathrm{O} \text { ambiente escolar aprimorou minha } \\
\text { capacidade de planejar. }\end{array}$ \\
\hline & & & AM_51 & $\begin{array}{l}\mathrm{O} \text { ambiente escolar aprimorou minha } \\
\text { criatividade. }\end{array}$ \\
\hline \multicolumn{2}{|c|}{$\begin{array}{l}\text { O ambiente da Universidade me permitiu } \\
\text { relacionar e analisar as variáveis que } \\
\text { influenciam no resultado de um problema, } \\
\text { aumentando minha capacidade de tomar } \\
\text { riscos calculados. }\end{array}$} & & AM_52 & $\begin{array}{l}\text { O ambiente escolar me ensinou a } \\
\text { tomar decisões quando enfrento um } \\
\text { problema, aprimorando minha } \\
\text { habilidade de assumir riscos } \\
\text { calculados. }\end{array}$ \\
\hline
\end{tabular}


(conclusão)

\begin{tabular}{|l|l|l|l|}
\hline \multicolumn{2}{|l|}{ VERSÃO ORIGINAL } & \multicolumn{1}{l|}{ VERSÃO ALTERADA } \\
\hline Questão & Referência & Ind. & Questão \\
\hline O ambiente universitário me forneceu & $\begin{array}{l}\text { Desenvolvido } \\
\text { pelos autores } \\
\text { com } \\
\text { vários contatos importantes, tanto pessoal } \\
\text { como profissionalmente. }\end{array}$ & $\begin{array}{l}\text { As atividades em feiras (FETEPS), } \\
\text { Fayolle eventos e workshops me } \\
\text { Liñán (2014) }\end{array}$ & $\begin{array}{l}\text { AM_53 } \\
\text { proporcionaram diversos contatos } \\
\text { importantes pessoal } \\
\text { profissionalmente. }\end{array}$ \\
\hline
\end{tabular}

Fonte: Autora.

Os autores concederam a permissão e o questionário foi realizado com 10 alunos do curso do ensino médio integrado ao técnico de Administração. O resultado foi positivo, os alunos não tiveram dificuldades em entender o instrumento e a média do tempo utilizado foi de 10 minutos. O instrumento final de pesquisa está no Apêndice B.

\subsection{ASPECTOS METODOLÓGICOS}

Para análise multivariada de dados, foi utilizado a modelagem estatística de equações estruturais no qual busca a explicação das relações entre múltiplas variáveis (HAIR et al., 2009, 2014).

Optou-se pelo software SMART PLS, cujo sistema baseia-se no método de modelagem parcial de mínimos quadrados (PLS-SEM) que tem como objetivo a previsão e a explicação dos construtos latentes e o método fornece um ponto comum entre modelagem de caminho e análise fatorial confirmatória (HAIR et al., 2009, 2014; MORAES; IIZUKA; PEDRO, 2018).

Outro motivo para essa escolha do PLS-SEM é a realização de uma análise de multigrupos (PLS-MGA) usada para comparação de parâmetros entre dois grupos ou mais. Para tal análise foi utilizada a técnica de Henseler no qual ocorre em 3 etapas:

a) separar a amostra em grupos, categorizando-as;

b) realização do procedimento de bootstrapping com o intuito de verificar os coeficientes de caminho, para por fim;

c) compará-los entre as categorias dos grupos, observando se há diferença e em quais categorias isso ocorre.

Os valores inferiores à 0,05 e superiores à 0,95 , evidenciam que as diferenças são significativas (SARSTEDT; HENSELER; RINGLE, 2011). Nessa pesquisa a análise multigrupos foi utilizada para analisar o curso técnico em Administração em relação aos outros cursos pesquisados. 
Apesar de receber respondentes de quatro unidades, a concentração maior da amostra foi da Etec Lauro Gomes (São Bernardo do Campo) e da Etec Juscelino Kubitschek de Oliveira (Diadema) em um total de 452 respondentes, no qual 161 alunos do curso técnico em Administração e 291 alunos de outros cursos:

a) Ensino Médio Regular;

b) Técnico em Logística, Desenvolvimento de Sistemas e Secretariado;

c) Ensino Técnico Integrado ao Médio de Mecatrônica, Automação Industrial e Química.

Para realização dessa pesquisa, a amostra final foi de 133 alunos do curso Técnico em Administração e 251 alunos de outros cursos, totalizando 384 respondentes. A coleta de dados ocorreu em fevereiro e março de 2019 com auxílio dos professores e coordenadores das unidades escolares.

Mais da metade dos alunos da amostra tem entre 15 e 17 anos (gráfico 8), em relação ao sexo os alunos estão distribuídos de maneira homogênea, $51 \%$ são homens e $49 \%$ são mulheres.

Gráfico 7- Idade dos alunos

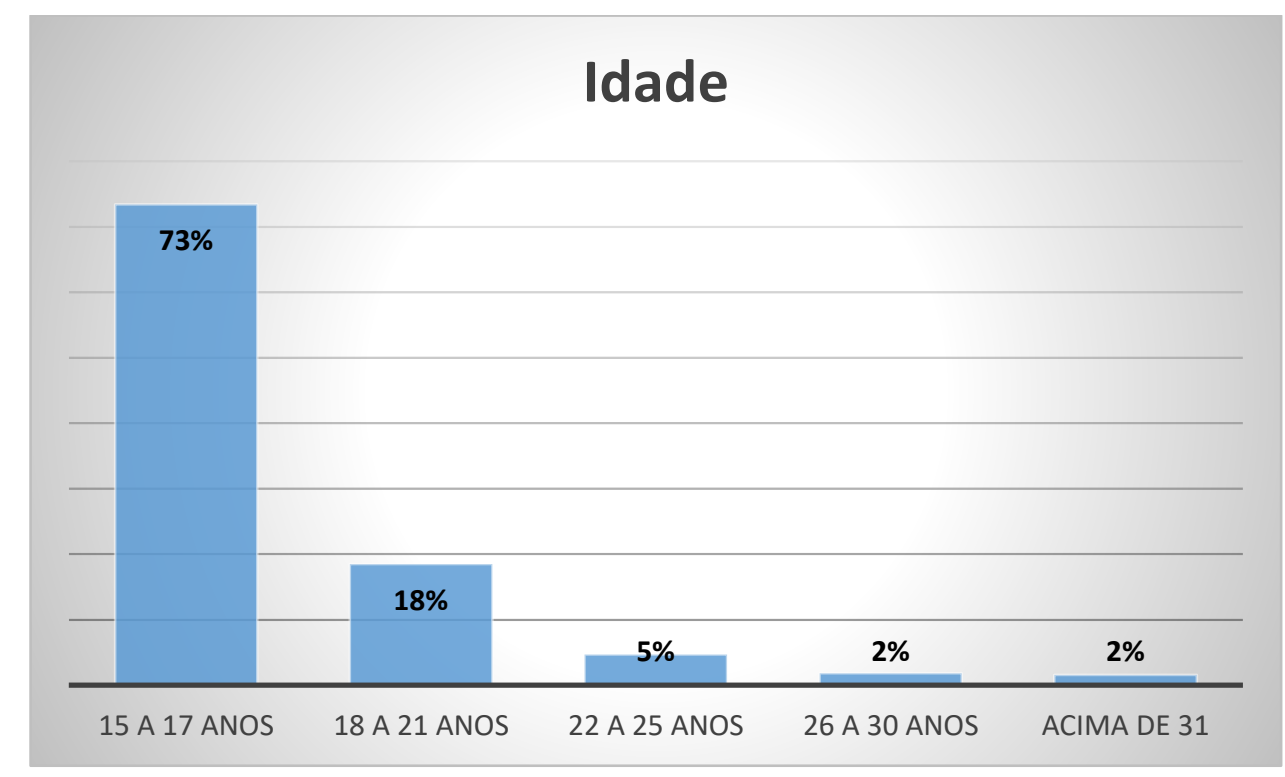

Fonte: Autora

A avaliação da amostra e do poder estatístico das análises foi realizada por meio do software G*Power 3.1(FAUL et al., 2007) e por recomendações de Chin (1998) e Hair et al. (2014). É considerado a maior quantidade de setas que chegam a um construto latente, no caso deste estudo são 5 (maior quantidade de preditores). Com um nível de significância de 5\%, 
poder estatístico de 0,8 e tamanho do efeito médio ( $\mathrm{f}^{2}=0,15$, que equivale a $\mathrm{R}^{2}=13 \%$ ), tem-se que o tamanho mínimo da amostra é 92, com a análise de multigrupos espera-se o dobro desse valor, como a amostra utilizada foi de 384 alunos é adequada a estimação por Partial least squares path modeling (PLS-PM). Para o tamanho do efeito médio o poder é de 0,99 , que é bem superior ao valor de 0,8 recomendado por Chin (1998) e Hair et al. (2014).

\subsection{DESCRIÇÃO E ANÁLISE DE RESULTADOS}

O modelo apresenta apenas indicadores reflexivos - Autoeficácia (AE), Ambiente Escolar (AM), Assumir Riscos (AR), Intenção Empreendedora (IE), Inovação (IN), Planejamento (PL) e Sociabilidade (SO), com isso os critérios realizados para as análises foram: consistência interna (confiabilidade composta); confiabilidade do indicador; validade convergente (variância média extraída); e validade discriminante (HAIR et al., 2009, 2014).

\subsubsection{Análise dos construtos reflexivos}

O primeiro critério analisado foi a validade convergente, respeitando os níveis indicados para variáveis latentes, no qual se referem que os indicadores com cargas superiores a 0,7 são significativos, já as cargas entre 0,4 e 0,7 devem ser avaliadas, pois a remoção desses indicadores podem afetar a variância do construto, e por fim, as cargas menores que 0,4 são recomendados que sejam removidas da pesquisa (HAIR et al., 2014; MORAES; IIZUKA; PEDRO, 2018). 
Tabela 1 - Cargas fatoriais

\begin{tabular}{|c|c|c|c|c|c|c|c|c|c|}
\hline Construto & Variável & $\mathbf{A E}$ & $\mathbf{A M}$ & $\mathbf{A R}$ & IE & IN & $\mathbf{L I}$ & PL & SO \\
\hline $\mathbf{A E}$ & $\begin{array}{l}\text { AE_36 } \\
\text { AE_37 } \\
\text { AE_38 } \\
\text { AE_39 } \\
\text { AE_40 } \\
\text { AE_41 } \\
\text { AE_42 } \\
\text { AE_43 } \\
\text { AE_44 }\end{array}$ & $\begin{array}{l}0.646 \\
0.581 \\
0.654 \\
0.349 \\
0.448 \\
0.722 \\
0.698 \\
0.621 \\
0.712\end{array}$ & & & & & & & \\
\hline $\mathbf{A M}$ & $\begin{array}{l}\text { AM_45 } \\
\text { AM_46 } \\
\text { AM_47 } \\
\text { AM_48 } \\
\text { AM_49 } \\
\text { AM_50 } \\
\text { AM_51 } \\
\text { AM_52 } \\
\text { AM_53 }\end{array}$ & & $\begin{array}{l}0.683 \\
0.590 \\
0.760 \\
0.670 \\
0.706 \\
0.687 \\
0.643 \\
0.612 \\
0.562\end{array}$ & & & & & & \\
\hline $\mathbf{A R}$ & $\begin{array}{l}\text { AR_23 } \\
\text { AR_24 } \\
\text { AR_25 } \\
\text { AR_26 }\end{array}$ & & & $\begin{array}{l}0.619 \\
0.789 \\
0.834 \\
0.709\end{array}$ & & & & & \\
\hline IE & $\begin{array}{l}\text { IE_31 } \\
\text { IE_32 } \\
\text { IE_33 } \\
\text { IE_34 } \\
\text { IE_35 }\end{array}$ & & & & $\begin{array}{l}0.718 \\
0.908 \\
0.909 \\
0.930 \\
0.920\end{array}$ & & & & \\
\hline IN & $\begin{array}{l}\text { IN_19 } \\
\text { IN_20 } \\
\text { IN_21 } \\
\text { IN_22 }\end{array}$ & & & & & $\begin{array}{l}0.742 \\
0.779 \\
0.525 \\
0.731\end{array}$ & & & \\
\hline $\mathbf{L I}$ & $\begin{array}{l}\text { LI_11 } \\
\text { LI_12 } \\
\text { LI_13 } \\
\text { LI_14 }\end{array}$ & & & & & & $\begin{array}{l}0.578 \\
0.597 \\
0.849 \\
0.738\end{array}$ & & \\
\hline PL & $\begin{array}{l}\text { PL_15 } \\
\text { PL_16 } \\
\text { PL_17 } \\
\text { PL_18 }\end{array}$ & & & & & & & $\begin{array}{l}0.723 \\
0.794 \\
0.781 \\
0.720\end{array}$ & \\
\hline SO & $\begin{array}{l}\text { SO_27 } \\
\text { SO_28 } \\
\text { SO_29 } \\
\text { SO_30 }\end{array}$ & & & & & & & & $\begin{array}{l}0.495 \\
0.745 \\
0.764 \\
0.740\end{array}$ \\
\hline
\end{tabular}

Fonte: Autora 
Diante disso, os indicadores que demonstraram carga inferior a 0,4 foram retirados da pesquisa (AE_39), os indicadores que tiveram suas cargas entre 0,4 e 0,7 foram analisados e extraídos os seguintes indicadores: AE_37, AE_39, AE_40, AE_43, AM_46, AM_51, AM_52, AM_53, IN_21, LI_11 e SO_27.

Outro indicador necessário para validação do modelo é o Average Variance Extracted (AVE), esse indicador representa o valor médio das cargas fatoriais quadradas dos indicadores associados ao construto em que seu valor deve ser superior a 0,5, ou seja, um AVE de 0,50 ou superior indica que, em média, o constructo explica mais da metade da variância de seus indicadores (HAIR et al., 2014; SARSTEDT; HENSELER; RINGLE, 2011).

Tabela 2 - Variância Média Extraída

\begin{tabular}{|c|c|}
\multicolumn{2}{|c|}{$\begin{array}{c}\text { Variância Média Extraída } \\
\text { (AVE) }\end{array}$} \\
\hline $\mathrm{AE}$ & 0.514 \\
\hline $\mathrm{AM}$ & 0.506 \\
\hline $\mathrm{AR}$ & 0.551 \\
\hline IE & 0.776 \\
\hline IN & 0.580 \\
\hline LI & 0.585 \\
\hline PL & 0.567 \\
\hline SO & 0.577 \\
\hline \multicolumn{2}{|c}{$\quad$ Fonte: Autora } \\
\hline
\end{tabular}

Fonte: Autora

Analisando a confiabilidade interna (tabela 3) do modelo temos outros dois critérios: a Confiabilidade Composta e o Alfa de Cronbach, o primeiro retrata o grau em que os indicadores refletem o construto latente em comum, já o segundo fornece uma estimativa da confiabilidade baseada nas intercorrelações das variáveis indicadoras observadas, assumindo que todos os indicadores são igualmente confiáveis. Ambos indicadores trabalham com o mesmo nível para validação, variando de 0 a 1 , no qual os valores mais próximos de 1 evidenciam que o construto será mais consistente internamente. Valores acima de 0,7 são os mais satisfatórios, porém para pesquisas exploratórias, valores entre 0,6 e 0,7, são considerados aceitáveis (HAIR et al., 2009, 2014). 
Tabela 3 - Confiabilidade Interna

\begin{tabular}{|c|c|c|}
\hline & $\begin{array}{l}\text { Alfa de } \\
\text { Cronbach }\end{array}$ & $\begin{array}{r}\text { Confiabilidade } \\
\text { composta }\end{array}$ \\
\hline $\mathrm{AE}$ & 0.762 & 0.841 \\
\hline $\mathbf{A M}$ & 0.785 & 0.835 \\
\hline $\mathbf{A R}$ & 0.735 & 0.829 \\
\hline IE & 0.925 & 0.945 \\
\hline IN & 0.639 & 0.806 \\
\hline LI & 0.651 & 0.803 \\
\hline PL & 0.751 & 0.840 \\
\hline SO & 0.636 & 0.803 \\
\hline
\end{tabular}

Fonte: Autora

A validez discriminante foi validada como retratada na tabela 4, o objetivo desse critério é evidenciar que a medida de um construto é distinto do outro, isto é, o construto é único e capta o fenômeno não representados por outros construtos no modelo (HAIR et al., 2009, 2014).

Tabela 4 - Validez discriminante

\begin{tabular}{|c|c|c|c|c|c|c|c|c|}
\hline & $\mathbf{A E}$ & $\mathbf{A M}$ & $\mathrm{AR}$ & IE & IN & LI & PL & SO \\
\hline $\mathbf{A E}$ & 0.717 & & & & & & & \\
\hline $\mathbf{A M}$ & 0.502 & 0.711 & & & & & & \\
\hline AR & 0.375 & 0.332 & 0.742 & & & & & \\
\hline IE & 0.452 & 0.573 & 0.325 & 0.881 & & & & \\
\hline IN & 0.476 & 0.336 & 0.324 & 0.352 & 0.762 & & & \\
\hline LI & 0.426 & 0.355 & 0.253 & 0.283 & 0.385 & 0.765 & & \\
\hline PL & 0.361 & 0.434 & 0.267 & 0.343 & 0.294 & 0.310 & 0.753 & \\
\hline SO & 0.447 & 0.357 & 0.271 & 0.341 & 0.318 & 0.390 & 0.363 & 0.760 \\
\hline
\end{tabular}

Fonte: Autora

\subsection{AVALIAÇÃO DO MODELO ESTRUTURAL}

A próxima etapa para avaliação do modelo estrutural é avaliar a colinearidade, ou seja, se existe correlação entre as variáveis, o VIF (Variance inflation fator) é o que dará o parâmetro de tolerância para essa medição, sendo eles valores superiores à 0,2 e inferiores a 5 (HAIR et al., 2009, 2014). A tabela 5 destaca que os valores estão dentro do padrão estabelecido. 
Tabela 5 - VIF

\begin{tabular}{|l|c|c|}
\hline \multicolumn{1}{|c}{ AE } & IE \\
\hline AE & & 1.336 \\
\hline AM & & 1.336 \\
\hline AR & 1.189 & \\
\hline IE & & \\
\hline IN & 1.306 & \\
\hline LI & 1.331 & \\
\hline PL & 1.248 & \\
\hline SO & 1.325 & \\
\hline
\end{tabular}

Fonte: Autora

Após essa verificação, é realizada a técnica de bootstrapping, no qual subamostras são sorteadas aleatoriamente (com substituição) do conjunto original de dados. Os autores Hair et al. (2014) recomendam que esse processo seja com 5.000 subamostras, ou pelo menos um número alto ou igual ao número de observações válidas no conjunto de dados. O intuito dessa técnica é analisar a significância dos indicadores mediante as cargas fatoriais estimando o modelo por meio das estimativas de parâmetros e seus intervalos de confiança (HAIR et al., 2014; MORAES; IIZUKA; PEDRO, 2018).

Com essa informação, o teste t de Student é calculado para avaliar a significância de cada peso do indicador, parte do pressuposto que os coeficientes de correlação são iguais a zero, se os resultados do teste apresentarem valores superiores a 1,96 indicam que a correlação é significativa (HAIR et al., 2014; MORAES; IIZUKA; PEDRO, 2018).

A tabela 6 apresenta que todas as relações obtiveram valores do teste $\mathrm{t}$ de Student superiores a 1,96 com nível de significância de $5 \%$.

Tabela 6 - Coeficientes do modelo estrutural

\begin{tabular}{|c|c|c|c|c|}
\hline \multicolumn{2}{|c|}{ Média } & Desvio Padrão & \multicolumn{1}{c|}{ Teste t } & P - Valor \\
\hline AE -> IE & 0,221 & 0,048 & 4,591 & 0,000 \\
\hline AM -> IE & 0,462 & 0,042 & 11,054 & 0,000 \\
\hline AR -> AE & 0,161 & 0,051 & 3,168 & 0,002 \\
\hline IN -> AE & 0,258 & 0,046 & 5,655 & 0,000 \\
\hline LI -> AE & 0,167 & 0,057 & 2,933 & 0,003 \\
\hline PL -> AE & 0,112 & 0,047 & 2,408 & 0,016 \\
\hline SO -> AE & 0,215 & 0,047 & 4,619 & 0,000 \\
\hline
\end{tabular}

Fonte: Autora 
Figura 2 - Coeficientes de caminho

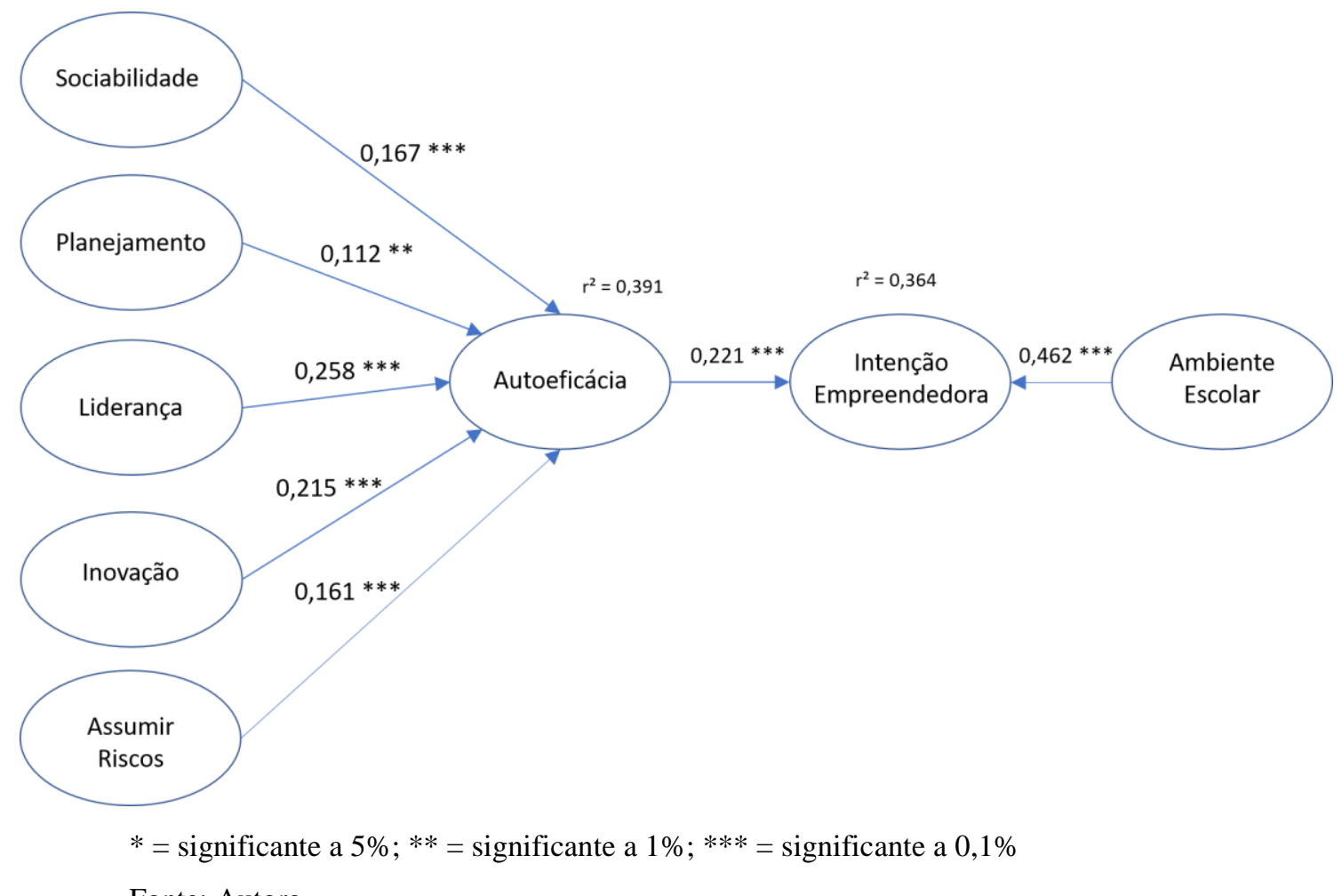

Fonte: Autora

Outras medidas utilizadas para avaliar o modelo estrutural são: o coeficiente de determinação $\left(\mathrm{r}^{2}\right)$ e o $\mathrm{q}^{2}$. $\mathrm{O} \mathrm{r}^{2}$ mede o quanto o modelo traz de precisão preditiva, sendo que seus valores variam de 0 a 1 , ou seja, valores mais próximos de 1 sugerem maior precisão preditiva, porém Hair et al. (2014) comentam que é difícil fornecer uma regra específica para um valor de $\mathrm{r}^{2}$ aceitável, pois depende da complexidade do modelo e da disciplina da pesquisa, já outros autores como Cohen (1988) e Faul et al. (2007) recomendam um parâmetro. Para valores $\mathrm{f}^{2}$ iguais a $0,02,0,15$ e 0,35 os valores de $\mathrm{r}^{2}$ e seus efeitos serão respectivamente $2 \%$ (pequeno), $13 \%$ (médio) e $25 \%$ (grande).

O indicador $q^{2}$ representa a relevância preditiva do modelo, para obtenção desse valor é necessário a utilização do procedimento de blindfolding no qual consiste em um processo iterativo que omite parte da matriz de dados e usa as estimativas do modelo para prever o que se omitiu. Valores de $\mathrm{q}^{2}$ maiores que 0 indicam relevância preditiva do modelo.

Na tabela 7 é possível visualizar os valores de $\mathrm{r}^{2}$ do construto de autoeficácia $(0,391)$ e intenção empreendedora $(0,361)$, ambos considerados altos, e o $q^{2}$ está dentro de seus respectivos parâmetros. 
Tabela 7 - Resultados de $\mathrm{r}^{2}$ e $\mathrm{q}^{2}$

\begin{tabular}{|c|c|c|c|}
\hline & $\mathbf{r}^{2}$ & $\mathbf{r}^{2}$ ajustado & $q^{2}$ \\
\hline $\mathbf{A E}$ & 0,391 & 0,382 & 0,183 \\
\hline IE & 0,364 & 0,361 & 0,260 \\
\hline
\end{tabular}

Fonte: Autora

$\mathrm{Na}$ análise multigrupos foi observado o relacionamento da variável CURSO em relação com as demais variáveis latentes, e verificado se existem diferenças do curso de técnico em Administração em relação aos demais cursos.

Tabela 8 - Análise Multigrupos

\begin{tabular}{|l|c|c|}
\hline & $\begin{array}{c}\text { Diferenças entre os } \\
\text { coeficientes - Curso }\end{array}$ & P - Valor \\
\hline AE -> IE & 0,101 & 0,169 \\
\hline AM -> IE & 0,019 & 0,416 \\
\hline AR -> AE & 0,055 & 0,707 \\
\hline IN -> AE & 0,036 & 0,662 \\
\hline LI -> AE & 0,204 & 0,025 \\
\hline PL -> AE & 0,095 & 0,157 \\
\hline SO -> AE & 0,149 & 0,950 \\
\hline
\end{tabular}

Fonte: Autora

Os resultados da tabela 8 mostram que existem diferenças significativas entre os relacionamentos de Liderança e Autoeficácia e Sociabilidade e Autoeficácia, neste caso a liderança e a sociabilidade em relação a autoeficácia dos alunos do curso técnico em Administração são mais intensas do que em alunos dos outros cursos.

Sendo assim na tabela 15, demonstra-se o resultado do teste de hipóteses deste estudo.

Quadro 6 - Resultado do Teste de Hipóteses

(continua)

\begin{tabular}{|c|c|c|}
\hline Hipóteses & Descrição & Resultado \\
\hline H1 & $\begin{array}{l}\text { A sociabilidade influencia positivamente a } \\
\text { autoeficácia. }\end{array}$ & CONFIRMADO \\
\hline H2 & $\begin{array}{l}\text { A capacidade de planejamento influencia } \\
\text { positivamente a autoeficácia. }\end{array}$ & CONFIRMADO \\
\hline H3 & $\begin{array}{l}\text { A capacidade de liderança influencia positivamente } \\
\text { a autoeficácia. }\end{array}$ & CONFIRMADO \\
\hline
\end{tabular}


(conclusão)

\begin{tabular}{|c|c|c|}
\hline Hipóteses & Descrição & Resultado \\
\hline H4 & $\begin{array}{l}\text { A capacidade de inovação influencia positivamente a } \\
\text { autoeficácia. }\end{array}$ & CONFIRMADO \\
\hline H5 & $\begin{array}{l}\text { Assumir riscos calculados influencia positivamente a } \\
\text { autoeficácia. }\end{array}$ & CONFIRMADO \\
\hline H6 & $\begin{array}{l}\text { A autoeficácia influencia positivamente a intenção } \\
\text { empreendedora. }\end{array}$ & CONFIRMADO \\
\hline H7 & $\begin{array}{l}\text { O ambiente escolar influencia positivamente a intenção } \\
\text { empreendedora. }\end{array}$ & CONFIRMADO \\
\hline H8a & $\begin{array}{l}\text { Existe diferença entre as relações de sociabilidade e } \\
\text { autoeficácia no que diz respeito ao curso. }\end{array}$ & CONFIRMADO \\
\hline H8b & $\begin{array}{l}\text { Existe diferença entre as relações de planejamento e } \\
\text { autoeficácia no que diz respeito ao curso. }\end{array}$ & NÃO CONFIRMADO \\
\hline H8c & $\begin{array}{l}\text { Existe diferença entre as relações de liderança e } \\
\text { autoeficácia no que diz respeito ao curso. }\end{array}$ & CONFIRMADO \\
\hline H8d & $\begin{array}{l}\text { Existe diferença entre as relações de assumir riscos } \\
\text { calculados e autoeficácia no que diz respeito ao curso. }\end{array}$ & NÃO CONFIRMADO \\
\hline H8e & $\begin{array}{l}\text { Existe diferença entre as relações de autoeficácia e } \\
\text { intenção empreendedora no que diz respeito ao curso. }\end{array}$ & NÃO CONFIRMADO \\
\hline H8f & $\begin{array}{l}\text { Existe diferença entre as relações de ambiente escolar e } \\
\text { intenção empreendedora no que diz respeito ao curso. }\end{array}$ & NÃO CONFIRMADO \\
\hline
\end{tabular}

Fonte: Autora

Com isso, é possível identificar que o ambiente escolar é o construto que mais influencia a intenção de empreender, isso demonstra que o aluno de ensino médio/técnico independente do curso no qual está inserido desenvolve um comportamento empreendedor por meio do ambiente escolar. Esse resultado vem confirmar o que os autores Dyer (1995) e Kourilsky e Walstad (1998) dizem, que a educação do empreendedorismo no ensino médio conduzida em um ambiente de apoio aumentará o interesse dos estudantes pelo assunto, como também, a sua preparação.

O construto da Autoeficácia também foi validado, ou seja, quanto mais o aluno acreditar que ele é capaz de realizar com sucesso vários papéis como: encontrar soluções criativas, trabalhar de forma produtiva e ver novas oportunidades de mercado, maior será sua intenção de empreender.

Em relação aos construtos que influenciam a autoeficácia o que mais se destacou foi a inovação, quanto mais os alunos se sentem criativos e em busca de novidades maior será sua autoeficácia. O segundo construto que mais influencia a autoeficácia foi a sociabilidade, quanto maior for a rede de contatos e relacionamentos, mais autoeficaz esse aluno será.

O construto da liderança também foi validado, no qual quanto maior for a influência do aluno sobre as pessoas para que possam superar conflitos e trabalhar em equipe maior será sua 
autoeficácia, seguido pelo construto de assumir riscos, quanto maior for a disposição em se arriscar, sair da zona de conforto, acreditar que isso trará vantagens e oportunidades, maior será a autoeficácia desse aluno.

E por fim, o construto planejamento, o qual se refere a poder se antecipar a acontecimentos e ter uma visão futura, nesse caso quanto maior for a preparação desse aluno visando o futuro mais autoeficaz o será.

Ao realizar a análise do resultado de multigrupos, ficou evidenciado que existe diferença quando se trata do curso técnico em Administração em relação a outros grupos, nos relacionamentos de liderança e autoeficácia e sociabilidade e autoeficácia. A diferença mais significativa se deu no indicador de liderança, no qual os alunos do curso de Administração se percebem ter essa característica mais proeminente do que os alunos de outros cursos, isso pode ocorrer porque umas das características do profissional de Administração é a liderança e o curso também por meio de sua base e atividades trabalha para que isso possa ser despertado nos alunos, ou o aluno que procura esse curso já tem uma predisposição ou um perfil direcionado a essa característica.

Em relação a sociabilidade, o que pode ter ocorrido é que os alunos dos cursos de química, mecatrônica, automação industrial e desenvolvimento de sistemas, têm perfis de baixa interação social, e a sociabilidade não é uma característica tão relevante para formação desses estudantes. 


\section{CONCLUSÃO}

Ao ensinar o empreendedorismo no ensino médio, percebe-se que existem duas abordagens: a primeira de maneira mais lúdica e subjetiva e a segunda de modo mais aplicado, voltado para o empreendedorismo mais tradicional. O ensino médio/técnico caracteriza-se mais pela segunda abordagem, pois seu objetivo é de formar os estudantes para o mercado profissional.

Por meio de um modelo que se mostrou apropriado ao ensino superior e após adaptação para o ensino médio/técnico, foi possível apresentar os eficientes resultados dessa pesquisa, evidenciando que o modelo foi adequado para o estudo, uma vez que a literatura acadêmica nacional e internacional é limitada e encontra-se num estágio inicial de investigações. Acreditamos que a escolha pelas ETECs e por alunos do ensino técnico favoreceu tal resultado, pois tais instituições de ensino, à semelhança das faculdades e universidades, buscam preparar os estudantes para o mundo do trabalho.

Diante dos resultados da pesquisa, pode-se replicar o modelo em outros colégios e contextos. No âmbito nacional é possível reproduzi-lo em outros cursos técnicos da mesma rede de ensino, como também, cursos técnicos de outras instituições, por exemplo, os institutos federais de ensino (IFES); em escolas técnicas rurais, analisando se o meio também tem impacto na intenção empreendedora. Considerando o âmbito internacional, é possível testá-lo em diversos países no qual o ensino médio/técnico faz parte da formação do jovem.

No tocante ao questionário, mesmo depois da adaptação realizada, foi percebido que os alunos tiveram certa dificuldade em respondê-lo, em algumas salas onde a quantidade de alunos era numerosa, alguns se dispersaram e ouve reclamações do tamanho do questionário e a quantidade de questões. Diante dessa limitação e a possibilidade de pesquisas futuras, uma nova versão do questionário poderia ser apresentada, como também uma modificação na estratégia de abordagem e aplicação aos alunos.

As hipóteses do modelo, no que se diz respeito às características empreendedoras, foram todas confirmadas, o que para quantidade da amostra, os resultados foram consistentes, confiáveis e estatisticamente válidos.

$\mathrm{Na}$ análise multigrupos foi observado que o relacionamento dos construtos de liderança e sociabilidade em relação a autoeficácia, indicaram diferença no que diz respeito aos cursos, esse resultado abre um espaço de pesquisa e análise, o qual indica-se que seja realizado um estudo mais aprofundado para entender quais são os fatores que levaram essa diferenciação do curso técnico em Administração em relação aos outros cursos, questionando o motivo pelo qual 
esses alunos tiveram essas características mais evidenciadas, a amostra deverá ser ampliada e testada em outros cursos técnicos e em outras Etecs.

As hipóteses que não foram confirmadas na análise multigrupos indicam que as demais características empreendedoras não possuem diferenças, ou seja, independente do curso os alunos têm a mesma percepção, isso deve ter ocorrido, provavelmente, em função do ambiente ser o mesmo; o perfil do estudante possuir semelhanças socioeconômicas, entre outros fatores. Algo que pode ser testado com outros estudantes.

Em relação à contribuição prática da pesquisa, pode-se afirmar com certo grau de segurança que o ambiente das duas Etecs estudadas tem influenciado a intenção de empreender dos seus estudantes. Para os gestores e professores dessas instituições essa pesquisa é um indicativo que o ensino, as atividades extracurriculares, as feiras, as ações de professores e alunos, dentre outras iniciativas estão tendo efeito positivo (ELERT; ANDERSSON; WENNBERG, 2015; PAÇO et al., 2011b). Nesse caso esse modelo poderá ser replicado também em outras Etecs para verificar em que medida suas instituições podem influenciar a intenção de empreender, como também, verificar se o resultado alcançado nessas duas escolas se confirma ou não. 


\section{REFERÊNCIAS}

AGUIAR, C. C. A Contribuição do Ensino Técnico na Formação e Educação Profissional do Curso em Administraçãa. 2013. 82f. Dissertação (Mestrado em Educação) Universidade do Oeste Paulista - UNOESTE, Presidente Prudente, 2013.

ARAÚJO, A. M.; DEMAI, F. M.; PRATA, M. Missão, Concepções e Práticas do Grupo de Formulações e Análises Curriculares (GFAC). 1. ed. São Paulo: Centro Estadual Paula Souza, 2017. Disponível em:

<http://www.cpscetec.com.br/cpscetec/arquivos/2014/missao.pdf>. Acesso em: 15 jul. 2018.

BANDURA, A. The Explanatory and Predictive Scope of Self-Efficacy Theory. Journal of Social and Clinical Psychology, [s. 1.], v. 4, n. 3, p. 359-373, 25.set.1986. Disponível em: <http://guilfordjournals.com/doi/10.1521/jscp.1986.4.3.359>. Acesso em: 14 nov. 2018.

BIRD, B. Implementing Entrepreneurial Ideas: The Case for Intention. Academy of Management Review, [s.1.], v. 13, n. 3, p. 442-453, jul.1988. Disponível em: <http://amr.aom.org/cgi/doi/10.5465/AMR.1988.4306970>. Acesso em: 2 fev. 2018.

BIRDTHISTLE, N.; HYNES, B.; FLEMING, P. Enterprise education programmes in secondary schools in Ireland. Education + Training, Ireland, v. 49, n. 4, p. 265-276, 5.jun.2007. Disponível em:

<http://www.emeraldinsight.com/doi/10.1108/00400910710754426>. Acesso em: 19 jul. 2018.

BONNETT, C.; FURNHAM, A. Who wants to be an entrepreneur? A study of adolescents interested in a Young Enterprise scheme. Journal of Economic Psychology, London, v. 12, n. 3, p. 465-478, set.1991. Disponível em:

<https://linkinghub.elsevier.com/retrieve/pii/016748709190027Q>. Acesso em: 9 set. 2018.

BOYLES, T.; COLLEGE, M. 21ST Century Knowledge, skills, and abilities and entrepreneurial competencies: A model for undergraduate entrepreneurship education. Journal of Entrepreneurship Education, Tennessee, v. 15, n. 3, p. 41-56, jan.2012. Disponível em: <https://academic.oup.com/jae/article-lookup/doi/10.1093/jae/ejm029>. Acesso em: 26 maio. 2018.

BRASIL. Lei no 13.415, de 16 de fevereiro de 2017. Brasília, GO. Disponível em: <http://legislacao.planalto.gov.br/legisla/legislacao.nsf/Viw_Identificacao/lei 13.4152017?OpenDocument>. Acesso em: 24 abr. 2018.

CARLAND, J. W.; HOY, F.; CARLAND, J. A. C. “Who is an Entrepreneur?” Is a Question Worth Asking. American Journal of Small Business, [s. 1.], v. 12, n. 4, p. 33-39, 4.abr.1988. Disponível em:

$<$ http://search.ebscohost.com/login.aspx ?direct=true \&db=buh\&AN=5748405\&site=ehostlive>. Acesso em: 7 fev. 2018.

CARVALHO, M. L. M. De. Cultura, saberes e práticas: memórias e história da edução profissional. 1. ed. São Paulo: Centro Paulo Souza, 2011.

CHEN, C. C.; GREENE, P. G.; CRICK, A. Does entrepreneurial self-efficacy distinguish 
entrepreneurs from managers? Journal of Business Venturing, [s.1.], v. 13, n. 4, p. 295-316, jul.1998. Disponível em: <https://linkinghub.elsevier.com/retrieve/pii/S0883902697000293>. Acesso em: 18 jun. 2017.

CHEUNG, C.; AU, E. Running a small business by students in a secondary school: its impact on learning about entrepreneurship. Journal of Entrepreneurship Education, [s. 1.], v. 13, p. 45-63, jan.2010. Disponível em:

<https://www.researchgate.net/publication/289177496_Running_a_small_business_by_stude nts_in_a_secondary_school_Its_impact_on_learning_about_entrepreneurship>.Acesso em: 1 out. 2017.

CHIN WW. The partial least squares approach for structural equation modeling. 1. ed. Mahwah: Lawrence Erlbaum, 1998. Disponível em: <https://psycnet.apa.org/record/199807269-010>. Acesso em: 13 maio. 2019.

COHEN, J. Statistical power analysis for the behavioral sciences. 2. ed. New York: Lawrence Earlbaum Associates., 1988.

COMMISSION, E. Entrepreneurship education in Europe: Fostering entrepreneurial mindsets through education and learning, Final Proceedings of the Conference on Entrepreneurship Education in Oslo. European Commission, Oslo, out. 2006. Disponível em: $<$ https://ec.europa.eu/growth/content/entrepreneurship-education-europe-fosteringentrepreneurial-mindsets-through-education-and_en>. Acesso em: 5 ago. 2018.

COSTA, M. A.; COUTINHO, E. H. L. Educação Profissional e a Reforma do Ensino Médio: lei n ${ }^{0}$ 13.415/2017. Educação \& Realidade, [s.1.], v. 43, n. 4, p. 1633-1652, 6.ago.2018. Disponível em: <http://www.scielo.br/scielo.php?script=sci_arttext\&pid=S217562362018000401633\&lng=pt\&tlng=pt $>$. Acesso em: 18 nov. 2018.

CRESWELL, J. W.; LOPES, M. Projeto de Pesquisa: Método Qualitativo, quantitativo e misto. 3. ed. Porto Alegre: SAGE, 2010.

CUNHA, L. A. Ensino Médio e Ensino Técnico na América Latina: Brasil, Argentina e Chile. Cadernos de Pesquisa, Brasília, p. 47-70, dez. 2000. Disponível em:

<http://publicacoes.fcc.org.br/ojs/index.php/cp/article/view/628/647>. Acesso em: 18 nov. 2018.

DIAFÉRIA, A. M.; IIZUKA, E. S. Análise do Potencial e Perfil Empreendedor dos Empresários Juniores de Administração no Brasil. 2016. TCC (Graduação em Administração) Centro Universitário da FEI, São Paulo, dez.2016.

DOLABELA, F. Oficina do empreendedor: A metodologia de ensino que ajuda a transformar conhecimento em riqueza. 1. ed. [s.1.] : Sextante, 2011.

DORNELAS, J. C. A. Empreendedorismo: transformando ideias em negócios. 4. ed. Rio de Janeiro: Elsevier, 2012.

DRUCKER, P. F. Inovação e Espírito Empreendedor: Prática e Princípios. 1. ed. [s.1.] : Cengage Learning, 2000.

DYER, W. G. Toward a Theory of Entrepreneurial Careers. Entrepreneurship Theory and Practice, [s. 1.], v. 19, n. 2, p. 7-21, 5.jan.1995. Disponível em: 
<http://journals.sagepub.com/doi/10.1177/104225879501900202>

ELERT, N.; ANDERSSON, F. W.; WENNBERG, K. The impact of entrepreneurship education in high school on long-term entrepreneurial performance. Journal of Economic Behavior \& Organization, Stockholm, v. 111, n. 1, p. 209-223, mar.2015. Disponível em: <http://dx.doi.org/10.1016/j.jebo.2014.12.020>. Acesso em: 8 jan. 2018.

ENGLE, R. L. et al. Entrepreneurial intent. International Journal of Entrepreneurial Behavior \& Research, [s. 1.], v. 16, n. 1, p. 35-57, 2.fev.2010. Disponível em: <http://www.emeraldinsight.com/doi/10.1108/13552551011020063>. Acesso em: 18 fev. 2018.

FAOITE, D. et al. Education and training for entrepreneurs: a consideration of initiatives in Ireland and The Netherlands. Education + Training, [s. 1.], v. 45, n. 8/9, p. 430-438, dez.2003. Disponível em:

<https://www.emeraldinsight.com/doi/10.1108/00400910310508829>. Acesso em: 8 jan. 2018.

FAUL, F. et al. G*Power 3: A flexible statistical power analysis program for the social, behavioral, and biomedical sciences. Behavior Research Methods, [s. 1.], v. 39, n. 2, p. 175191, maio2007. Disponível em: <http://www.springerlink.com/index/10.3758/BF03193146>. Acesso em: 13 maio. 2019.

FAYOLLE, A.; LIÑÁN, F. The future of research on entrepreneurial intentions. Journal of Business Research, [s. 1.], v. 67, n. 5, p. 663-666, maio2014. Disponível em: <http://dx.doi.org/10.1016/j.jbusres.2013.11.024>. Acesso em: 7 fev. 2018.

FERRETI, C. J.; SILVA, M. R. Reforma do Ensino Médio no Contento da Medida Provisória N o 746/2016: Estado, Currículo e Disputas por hegemonia. Educação \& Sociedade, Campinas, v. 38, n. 139, p. 385-404, jun.2017. Disponível em: <http://www.scielo.br/scielo.php?script=sci_arttext\&pid=S0101$73302017000200385 \& \operatorname{lng}=$ pt\&tlng=pt>. Acesso em: 19 nov. 2018.

FIET, J. O. The pedagogical side of entrepreneurship theory. Journal of Business Venturing, Louisville, v. 16, n. 2, p. 101-117, mar.2001. Disponível em: <https://linkinghub.elsevier.com/retrieve/pii/088390269190002U>. Acesso em: 18 jul. 2017.

FILION, L. J. Ten Steps to Entrepreneurial Teaching. Journal of Small Business \& Entrepreneurship, [s. 1.], v. 11, n. 3, p. 68-78, 2.jan.1994. Disponível em: <http://www.tandfonline.com/doi/abs/10.1080/08276331.1994.10600466>. Acesso em: 5 nov. 2018.

FILION, L. J. Empreendedorismo e gerenciamento: processos distintos, porém complementares. Revista de Administração de Empresas, [s. 1.], v. 40, n. 3, p. 2-7, set.2000. Disponível em: <http://www.scielo.br/scielo.php?script=sci_arttext\&pid=S0034$75902000000300013 \& \operatorname{lng}=$ pt\&tlng=pt $>$. Acesso em: 10 fev. 2019.

GARAVAN, T. N.; O'CINNEIDE, B. Entrepreneurship Education and Training. Education + Training, [s.1.], v. 46, n. 3, abr.2004. Disponível em: <http://www.emeraldinsight.com/doi/10.1108/03090599410068024>. Acesso em: 5 nov. 2018. 
GATEWOOD, E. J. et al. Entrepreneurial Expectancy, Task Effort, and Performance. Entrepreneurship Theory and Practice, [s.1.], v. 27, n. 2, p. 187-206, 4.abr.2002. Disponível em: <http://journals.sagepub.com/doi/10.1111/1540-8520.00006>. Acesso em: 7 fev. 2018.

GIBB, A. A. Enterprise Culture - Its Meaning and Implications for Education and Training. Journal of European Industrial Training, [s. 1.], v. 11, n. 2, p. 2-38, fev.1987. Disponível em: <http://www.emeraldinsight.com/doi/10.1108/eb043365>. Acesso em: 10 jan. 2019.

GIOVANELA, A. et al. As características da disciplina de empreendedorismo em Instituições de Ensino Superior (IES) do Estado de Santa Catarina. Revista Gestão Universitária na América Latina - GUAL, [s.1.], v. 3, n. 1, p. 69-84, 5.jun.2012. Disponível em:

<http://www.periodicos.ufsc.br/index.php/gual/article/view/24972>. Acesso em: 15 out. 2018.

GUPTA, V.; FERNANDEZ, C. Cross-Cultural Similarities and Differences in Characteristics Attributed to Entrepreneurs. Journal of Leadership \& Organizational Studies, [s.1.], v. 15, n. 3, p. 304-318, fev.2009. Disponível em: <http://journals.sagepub.com/doi/10.1177/1548051808326036>. Acesso em: 7 fev. 2018.

HAIR, J. F. et al. Análise Multivariada de Dados. 6. ed. Porto Alegre: Bookman, 2009.

HAIR, J. J. et al. Partial least squares structural equation modeling (PLS-SEM). European

Business Review, Los Angeles, v. 26, n. 2, p. 106-121, 4.mar.2014. Disponível em: <http://www.emeraldinsight.com/doi/10.1108/EBR-10-2013-0128>. Acesso em: 29 abr. 2019.

HENRIQUE, D. C.; CUNHA, S. K. Da. Práticas didático-pedagógicas no ensino de empreendedorismo em cursos de graduação e pós-graduação nacionais e internacionais.

RAM. Revista de Administração Mackenzie, [s. 1.], v. 9, n. 5, p. 112-136, 2008. Disponível em: <http://www.scielo.br/scielo.php?script=sci_arttext\&pid=S1678-

$69712008000500006 \& \operatorname{lng}=p t \& t \operatorname{lng}=\mathrm{pt}>$

HENRY, C.; HILL, F.; LEITCH, C. Entrepreneurship education and training: can entrepreneurship be taught? Part II. Education + Training, Ireland, v. 47, n. 3, p. 158-169, abr.2005. Disponível em:

<https://www.emeraldinsight.com/doi/10.1108/00400910510592211>. Acesso em: 2 nov. 2018.

HICKIE, J. The Development of Human Capital in Young Entrepreneurs. Industry and Higher Education, [s.1.], v. 25, n. 6, p. 469-481, dez.2011. Disponível em: <http://journals.sagepub.com/doi/10.5367/ihe.2011.0070>. Acesso em: 15 out. 2018.

HONIG, B. Entrepreneurship Education: Toward a Model of Contingency-Based Business Planning. Academy of Management Learning \& Education, [s.1.], v. 3, n. 3, p. 258-273, set.2004. Disponível em: <http://journals.aom.org/doi/10.5465/amle.2004.14242112>. Acesso em: 15 out. 2018.

HUBER, L. R.; SLOOF, R.; VAN PRAAG, M. The effect of early entrepreneurship education: Evidence from a field experiment. European Economic Review, Amsterdam, v. 72, n. 12, p. 76-97, nov.2014. Disponível em: <https://linkinghub.elsevier.com/retrieve/pii/S0014292114001263>. Acesso em: 15 nov. 2018. 
IIZUKA, E. S. Experiências Inovadoras de ensino e aprendizagem - Prêmio FEI Inova Paula Souza. 1. ed. São Paulo: Centro Universitário da FEI, Centro Paula Souza, 2015. Disponível em: <https://fei.edu.br/sites/premio/FEI_2015.pdf>. Acesso em: 24 nov. 2018.

IIZUKA, E. S.; MORAES, G. H. S. M. Análise do Potencial e Perfil Empreendedor do Estudante de Administração e o Ambiente Universitário: Reflexões Para Instituições de Ensino. Administração: Ensino e Pesquisa, [s. 1.], v. 15, n. 3, p. 593, 30.set.2014.

Disponível em: <http://raep.emnuvens.com.br/raep/article/view/16>. Acesso em: 8 out. 2017.

ILANDER, G. P. B. The use of feature films to promote entrepreneurship. International Journal of Information and Operations Management Education, [s.1.], v. 3, n. 3, p. 284, maio2010. Disponível em: <http://www.inderscience.com/link.php?id=33551>. Acesso em: 15 out. 2018.

INSTITUTO FAZENDO ACONTECER. Nossa metodologia - Instituto Fazendo Acontecer. 2018. Disponível em: 〈https://www.fazendoacontecer.org.br/conheca-o-f-a/>. Acesso em: 24 nov. 2018.

JOHANSEN, V. Entrepreneurship education and entrepreneurial activity. International Journal of Entrepreneurship and Small Business, [s. 1.], v. 9, n. 1, p. 74, 2010. Disponível em: <http://www.inderscience.com/link.php?id=29507>. Acesso em: 5 mar. 2018.

KATZ, J. A. The chronology and intellectual trajectory of American entrepreneurship education. Journal of Business Venturing, Saint Louis, v. 18, n. 2, p. 283-300, mar.2003. Disponível em: <https://linkinghub.elsevier.com/retrieve/pii/S0883902602000988>. Acesso em: 2 nov. 2018.

KLAPPER, R.; LÉGER-JARNIOU, C. Entrepreneurship Intention among French Grande ÉCole and University Students. Industry and Higher Education, Paris, v. 20, n. 2, p. 97 110, 4.abr.2006. Disponível em:

<http://journals.sagepub.com/doi/10.5367/000000006777699900>. Acesso em: 18 fev. 2019.

KNOTTS, T. L.; COLLEGE, B. S. The Sbdc in the Classroom: Providing Experiential Learning Opportunities at Different Entrepreneurial Stages. Journal of Entrepreneurship Education, [s.1.], v. 14, n. 2, p. 25-38, 1.ago.2011. Disponível em: <http://www.regepe.org.br/index.php/regepe/article/view/563>. Acesso em: 15 out. 2018.

KOURILSKY, M. L.; WALSTAD, W. B. Entrepreneurship and female youth: knowledge, attitudes, gender differences, and educational practices. Journal of Business Venturing, [s.1.], v. 13, n. 1, p. 77-88, jan.1998. Disponível em:

<https://www.sciencedirect.com/science/article/abs/pii/S0883902697000323>. Acesso em: 5 mar. 2018.

KRUEGER, N. F.; BRAZEAL, D. V. Entrepreneurial Potential and Potential Entrepreneurs. Entrepreneurship Theory and Practice, [s.1.], v. 18, n. 3, p. 91-104, abr.1994. Disponível em: <http://journals.sagepub.com/doi/10.1177/104225879401800307>. Acesso em: 7 fev. 2018.

KRUEGER, N. F.; REILLY, M. D.; CARSRUD, A. L. Competing models of entrepreneurial intentions. Journal of Business Venturing, [s. 1.], v. 15, n. 5, p. 411-432, set.2000.

Disponível em: <http://linkinghub.elsevier.com/retrieve/pii/S0883902698000330>. Acesso em: 26 nov. 2017. 
KURATKO, D. F. The Emergence of Entrepreneurship Education: Development, Trends, and Challenges. Entrepreneurship Theory and Practice, [s.1.], v. 29, n. 5, p. 577-598, set.2005. Disponível em: <http://journals.sagepub.com/doi/10.1111/j.1540-6520.2005.00099.x>. Acesso em: 15 out. 2018.

LAUTENSCHLÄGER, A.; HAASE, H. The Myth of Entrepreneurship Education: Seven Arguments Against Teaching Business Creation at Universities. Journal Entrepreneurship Education, [s.1.], v. 14, n. 1, p. 147-161, nov.2011.

LECHUGO, C. P. A educação tecnológica: sua história, seus professores e a percepção dos alunos sobre as práticas pedagógicas. 2016. 249f. Tese (Doutorado em Educação) Universidade de Sorocaba, Sorocaba, 2016.

LEE, S. M.; CHANG, D.; LIM, S. Impact of Entrepreneurship Education: A Comparative Study of the U.S. and Korea. The International Entrepreneurship and Management Journal, [s.1.], v. 1, n. 1, p. 27-43, mar.2005. Disponível em: <http://link.springer.com/10.1007/s11365-005-6674-2>. Acesso em: 6 jan. 2018.

LEPOUTRE, J. et al. A new approach to testing effects of entrepreneurship education among secondary schools pupils. Vlerivk Leuven Gent Management, [s.1.], 2010.

LIÑÁN, F.; CHEN, Y. Development and Cross-Cultural Application of a Specific Instrument to Measure Entrepreneurial Intentions. Entrepreneurship Theory and Practice, [s.1.], v. 33, n. 3, p. 593-617, maio2009. Disponível em: <http://journals.sagepub.com/doi/10.1111/j.15406520.2009.00318.x>. Acesso em: $26 \mathrm{dez} .2017$.

MANFREDI, S. M. Educação profissional no Brasil. São Paulo: Cortez Editora, 2002.

MARKMAN, G. D.; BARON, R. A. Person-entrepreneurship fit: why some people are more successful as entrepreneurs than others. Human Resource Management Review, [s.l.], v. 13, n. 2, p. 281-301, jun.2003. Disponível em:

<https://linkinghub.elsevier.com/retrieve/pii/S1053482203000184>. Acesso em: 7 fev. 2018.

MARQUES, C. S. et al. Factors Preceding the Formation of Entrepreneurial Intention: An Applied Study of Secondary School Students. European Conference on Innovation and Entrepreneurship, [s. 1.], v. 2, n. 1, p. 456-465, jun.2012.

MAYER, R. Proposta Metodológica de Empreendedorismo no Ensino Médio: Uma aplicação no CEFET - PR. 2001. 140f. Dissertação (Mestrado em Engenharia de Produção) Universidade Federal de Santa Catarina, Florianópolis, 2001.

MCCLELLAND, D. C. The achieving society. [s.1.] : Van Nostrand, 1961. Disponível em: $<$ https://books.google.com.br/books?hl=pt-

$\mathrm{BR} \& 1 \mathrm{r}=\& \mathrm{id}=\mathrm{R} 12 \mathrm{wZ}$ w9AFE4C\&oi=fnd\&pg=PA1\&ots=NHOj2gsCB7\&sig=F_LYPRKuU1zk Vau7Wj9MhTtYO5w\&redir_esc=y\#v=onepage\&q\&f=false>. Acesso em: 26 maio. 2019.

MEC- MINISTÉRIO DA EDUCAÇÃO. Base Nacional Comum Curricular: Educação é a base. [s.1.] : Ministério da Educação, 2017. Disponível em:

$<\mathrm{http}$ ://basenacionalcomum.mec.gov.br/wp-

content/uploads/2018/04/BNCC_EnsinoMedio_embaixa_site.pdf>

MOITA, F. M. G. da S. C.; ANDRADE, F. C. B. De. Ensino-pesquisa-extensão: um exercício 
de indissociabilidade na pós-graduação. Revista Brasileira de Educação, [s.1.], v. 14, n. 41, p. 269-280, ago.2009. Disponível em:

<http://www.scielo.br/scielo.php?script=sci_arttext\&pid=S1413-

$24782009000200006 \& \operatorname{lng}=$ pt\&tlng=pt $>$. Acesso em: 25 nov. 2018.

MORAES, G. H. S. M. De; IIZUKA, E. S.; PEDRO, M. Effects of Entrepreneurial Characteristics and University Environment on Entrepreneurial Intention. Revista de Administração Contemporânea, São Paulo, v. 22, n. 2, p. 226-248, abr.2018. Disponível em: <http://www.scielo.br/scielo.php?script=sci_arttext\&pid=S141565552018000200226\&lng=en\&tlng=en>. Acesso em: 5 nov. 2018.

MOURA, D. H. A relação entre a educação profissional e a Educação Básica na CONAE 2010: Possibilidades e limites para a construção do novo Plano Naciona de Educação.

Educação \& Sociedade, [s.1.], v. 31, n. 112, p. 875-894, jul.2010.

NEWMAN, A. et al. Entrepreneurial self-efficacy: A systematic review of the literature on its theoretical foundations, measurement, antecedents, and outcomes, and an agenda for future research. Journal of Vocational Behavior, [s.1.], v. 110, n. 2017, p. 403-419, fev.2019. Disponível em: <https://doi.org/10.1016/j.jvb.2018.05.012>. Acesso em: 2 maio. 2019.

PAÇO, A. et al. Entrepreneurial intention among secondary students: findings from Portugal. International Journal of Entrepreneurship and Small Business, Covilhã, v. 13, n. 1, p. 92, maio2011a. Disponível em: <http://www.inderscience.com/link.php?id=40418>. Acesso em: 10 jan. 2018.

PAÇO, A. M. F. et al. Behaviours and entrepreneurial intention: Empirical findings about secondary students. Journal of International Entrepreneurship, Covilhã, v. 9, n. 1, p. 2038, 7.mar.2011b. Disponível em: <http://link.springer.com/10.1007/s10843-010-0071-9>. Acesso em: 1 out. 2017.

PEREIRA, S. P. Educação Profissional e Competências profissionais: Um estudo com egresso do ensino técnicno modular. 2018. 141f. Dissertação (Mestrado Profissional Gestão e Desenvolvimento da Educação Profissional) Centro Estadual de Educação Tecnológica Paula Souza, São Paulo, 2018.

PETERMAN, N. E.; KENNEDY, J. Enterprise Education: Influencing Students' Perceptions of Entrepreneurship. Entrepreneurship Theory and Practice, [s.1.], v. 28, n. 2, p. 129-144, mar.2003. Disponível em: 〈http://doi.wiley.com/10.1046/j.1540-6520.2003.00035.x〉. Acesso em: 18 jun. 2017.

PETERSON, R.; LIMBU, Y. Student Characteristics and Perspectives in Entrepreneurship Courses: A Profile. Journal of Entrepreneurship Education, [s.1.], v. 13, p. 65-84, abr.2010. Disponível em: <http://www.alliedacademies.org/Publications/Papers/JEE Vol 13 2010 p 65-83.pdf>. Acesso em: 15 out. 2018.

PIPEROPOULOS, P.; DIMOV, D. Burst Bubbles or Build Steam? Entrepreneurship Education, Entrepreneurial Self-Efficacy, and Entrepreneurial Intentions. Journal of Small Business Management, [s.1.], v. 53, n. 4, p. 970-985, out.2015. Disponível em: <http://doi.wiley.com/10.1111/jsbm.12116>. Acesso em: 7 fev. 2018.

PITTAWAY, L. et al. The role of entrepreneurship clubs and societies in entrepreneurial learning. International Small Business Journal: Researching Entrepreneurship, [s.1.], v. 
29, n. 1, p. 37-57, 21.fev.2011. Disponível em:

<http://journals.sagepub.com/doi/10.1177/0266242610369876>. Acesso em: 7 fev. 2018.

RENKO, M. et al. Understanding and Measuring Entrepreneurial Leadership Style. Journal of Small Business Management, Chicago, v. 53, n. 1, p. 54-74, jan.2015. Disponível em: <http://doi.wiley.com/10.1111/jsbm.12086>. Acesso em: 17 fev. 2019.

ROCHA, E. L. de C.; FREITAS, A. A. F. Avaliação do Ensino de Empreendedorismo entre Estudantes Universitários por meio do Perfil Empreendedor. Revista de Administração Contemporânea, Rio de Janeiro, v. 18, n. 4, p. 465-486, ago.2014. Disponível em: <http://www.anpad.org.br/rac\%5Cnhttp://dx.doi.org/10.1590/1982-

7849rac20141512\%5Cnwww.anpad.org.br/rac>. Acesso em: 26 nov. 2017.

RUIZ, E. F. De. O efeito da burocracia no desempenho escolar: o caso do Centro Paula Souza. 2014. 124f. Dissertação (Mestrado em Administração Pública e Governo) Fundação Getúlio Vargas - FGV, São Paulo, 2014.

RUSKOVAARA, E. et al. Studying teachers' teaching methods and working approaches in entrepreneurship education. Proceedings of the 7th ESU Conference., [s. 1.], p. 1-18, 27.fev.2010. Disponível em:

<https://developmentcentre.lut.fi/files/muut/ESU_2010_Tartto_2.pdf>. Acesso em: 15 set. 2018.

SAEED, S. et al. The Role of Perceived University Support in the Formation of Students' Entrepreneurial Intention. Journal of Small Business Management, Padova, v. 53, n. 4, p. 1127-1145, out.2015. Disponível em: <http://doi.wiley.com/10.1111/jsbm.12090>. Acesso em: 15 set. 2017.

SARSTEDT, M.; HENSELER, J.; RINGLE, C. M. Multigroup Analysis in Partial Least Squares (PLS) Path Modeling: Alternative Methods and Empirical Results. [s.l.]. v. 22 Disponível em: <http://www.emeraldinsight.com/doi/10.1108/S14747979\%282011\%290000022012>

SCHMIDT GODOY, A.; ANTONELLO, C. S. Competências individuais adquiridas durante os anos de graduação de alunos do Curso de Administração de Empresas. Revista de Ciências da Administração, [s. 1.], v. 11, n. 23, p. 157-191, 24.ago.2009. Disponível em: <http://www.periodicos.ufsc.br/index.php/adm/article/view/11347>. Acesso em: 25 nov. 2018.

SCHMIDT, S.; BOHNENBERGER, M. C. Perfil empreendedor e desempenho organizacional. Revista de Administração Contemporânea, [s. 1.], v. 13, n. 3, p. 450-467, 2009.

SCHWARZ, E. J. et al. The effects of attitudes and perceived environment conditions on students' entrepreneurial intent. Education + Training, Klagenfurt, v. 51, n. 4, p. 272-291, maio2009. Disponível em:

<https://www.emeraldinsight.com/doi/10.1108/00400910910964566>

SEBRAE - SERVIÇO BRASILEIRO DE APOIO ÁS MICROS E PEQUENAS EMPRESAS. A proposta de Educação Empreendedora do Sebrae. 2018. Disponível em: <http://www.sebrae.com.br/sites/PortalSebrae/sebraeaz/a-proposta-de-educacaoempreendedora-do-sebrae,b741be061f736410VgnVCM2000003c74010aRCRD>. Acesso em: 
24 nov. 2018.

SOUZA, A. M. As Metodologias Ativas na Prática de Docentes no Ensino Profissional. 2016. 87 f. Dissertação (Mestre em Educação Pontifícia Universidade Católica de São Paulo PUC, São Paulo, 2016.

SOUZA, C. P. Centro Paula Souza - 45 anos, 45 motivos de sucesso. 1. ed. São Paulo: Imprensa Oficial, 2015.

SOUZA, C. P. Relatório de Gestão Centro Paula Souza 2012 - 2016. 1. ed. São Paulo: Centro Paulo Souza, 2017a.

SOUZA, C. P. Perfil dos Cursos 2017. 1. ed. São Paulo: Imprensa Oficial, 2017b.

TOP, S.; ÇOLAKOĞLU, N.; DILEK, S. Evaluating Entrepreneurship Intentions of Vocational High School Pupils Based On Self- Efficacy Concept. Procedia - Social and Behavioral Sciences, [s. 1.], v. 58, p. 934-943, out.2012. Disponível em: <http://linkinghub.elsevier.com/retrieve/pii/S187704281204534X>. Acesso em: 25 nov. 2017.

TURKER, D.; SONMEZ SELCUK, S. Which factors affect entrepreneurial intention of university students? Journal of European Industrial Training, [s.1.], v. 33, n. 2, p. 142-159, fev.2009. Disponível em:

<http://www.emeraldinsight.com/doi/10.1108/03090590910939049>. Acesso em: 15 set. 2017.

UEMURA, M. R. B. Fatores determinantes no desempenho das escolas de ensino profissionalizante integrado ao médio: um estudo de caso dos municípios de Cotia e São Roque. 2016. 175f. Dissertação (Mestrado em Ciências) Universidade de São Paulo - USP, São Paulo, 2016.

VECCHIO, R. P. Entrepreneurship and leadership: common trends and common threads. Human Resource Management Review, [s.1.], v. 13, n. 2, p. 303-327, jun.2003. Disponível em: 〈https://linkinghub.elsevier.com/retrieve/pii/S1053482203000196>

XU, X.; NI, H.; YE, Y. Factors influencing entrepreneurial intentions of Chinese secondary school students: an empirical study. Asia Pacific Education Review, Seoul, v. 17, n. 4, p. 625-635, dez.2016. Disponível em: <http://link.springer.com/10.1007/s12564-016-9439-4>. Acesso em: 13 ago. 2017.

ZAMBON, S. A. Educação Empreendedora: Análise dos temas abordados no Ensino Fundamental , Médio e Superior. 2014. 168f. Dissertação (Mestrado em Ciência, Tecnologia e Sociedade) Universidade Federal de São Carlos, São Carlos, 2014.

ZANIRATO, C. L. Mapeamento das Escolas Técnicas - Dados Gerais, Eixos Tecnológicos e Cursos Oferecidos. São Paulo: CEETEPS, 2017.

ZHAO, H.; SEIBERT, S. E.; HILLS, G. E. The Mediating Role of Self-Efficacy in the Development of Entrepreneurial Intentions. Journal of Applied Psychology, [s. 1.], v. 90, n. 6, p. 1265-1272, jan.2005. Disponível em: <http://doi.apa.org/getdoi.cfm?doi=10.1037/00219010.90.6.1265>. Acesso em: 12 maio. 2019. 
APÊNDICE A - Eixos Tecnológicos do Centro Paula Souza 


\begin{tabular}{|c|c|}
\hline EIXO TECNOLÓGIO & HABILITAÇÕES (Cursos) \\
\hline 1. Ambiente e Saúde (12 cursos) & $\begin{array}{l}\text { - } \text { Agente Comunitário de Saúde } \\
\text { - } \text { Biotecnologia } \\
\text { - } \text { Cuidador de Idosos } \\
\text { - } \text { Enfermagem } \\
\text { - } \text { Meio Ambiente } \\
\text { - Meio Ambiente Integrado ao Médio } \\
\text { - Nutrição e Dietética } \\
\text { - Nutrição e Dietética Integrado ao Médio } \\
\text { - Órteses e Próteses } \\
\text { - } \text { Prótese Dentária } \\
\text { - Saúde Bucal }\end{array}$ \\
\hline $\begin{array}{l}\text { 2. Controle e Processos } \\
\text { Industriais ( } 20 \text { cursos) }\end{array}$ & $\begin{array}{l}\text { - } \text { Automação Industrial } \\
\text { - } \text { Butomação Industrial Integrado ao Médio } \\
\text { - } \text { Eletroeletrônica } \\
\text { - } \\
\text { - Eletroeletrônica Integrado ao Médio } \\
\text { - Eletrônicânica } \\
\text { - Eletrônica (EAD) } \\
\text { - Eletrônica Integrado ao Médio } \\
\text { - Eletrotécnica } \\
\text { - Instrumentação } \\
\text { - Manutenção Automotiva } \\
\text { - Mecânica } \\
\text { - Mecânica Integrado ao Médio } \\
\text { - Mecatrônica } \\
\text { - Mecatrônica Integrado ao Médio } \\
\text { - Metalurgia (Produção de Peças Metálicas) } \\
\text { - Projetos Mecânicos }\end{array}$ \\
\hline $\begin{array}{l}\text { 3. Desenvolvimento Educacional } \\
\text { e Social ( } 2 \text { cursos) }\end{array}$ & $\begin{array}{l}\text { - Biblioteca } \\
\text { - Orientação Comunitária }\end{array}$ \\
\hline 4. Gestão e Negócios ( 25 cursos) & $\begin{array}{l}\text { - Administração } \\
\text { - Administração - EAD } \\
\text { - Administração - EJA } \\
\text { - Administração Integrado ao Médio } \\
\text { - Comércio } \\
\text { - Comercio - EAD } \\
\text { - Contabilidade } \\
\text { - Contabilidade Integrado ao Médio } \\
\text { - Finanças } \\
\text { - Legislativo } \\
\text { - Logística }\end{array}$ \\
\hline
\end{tabular}




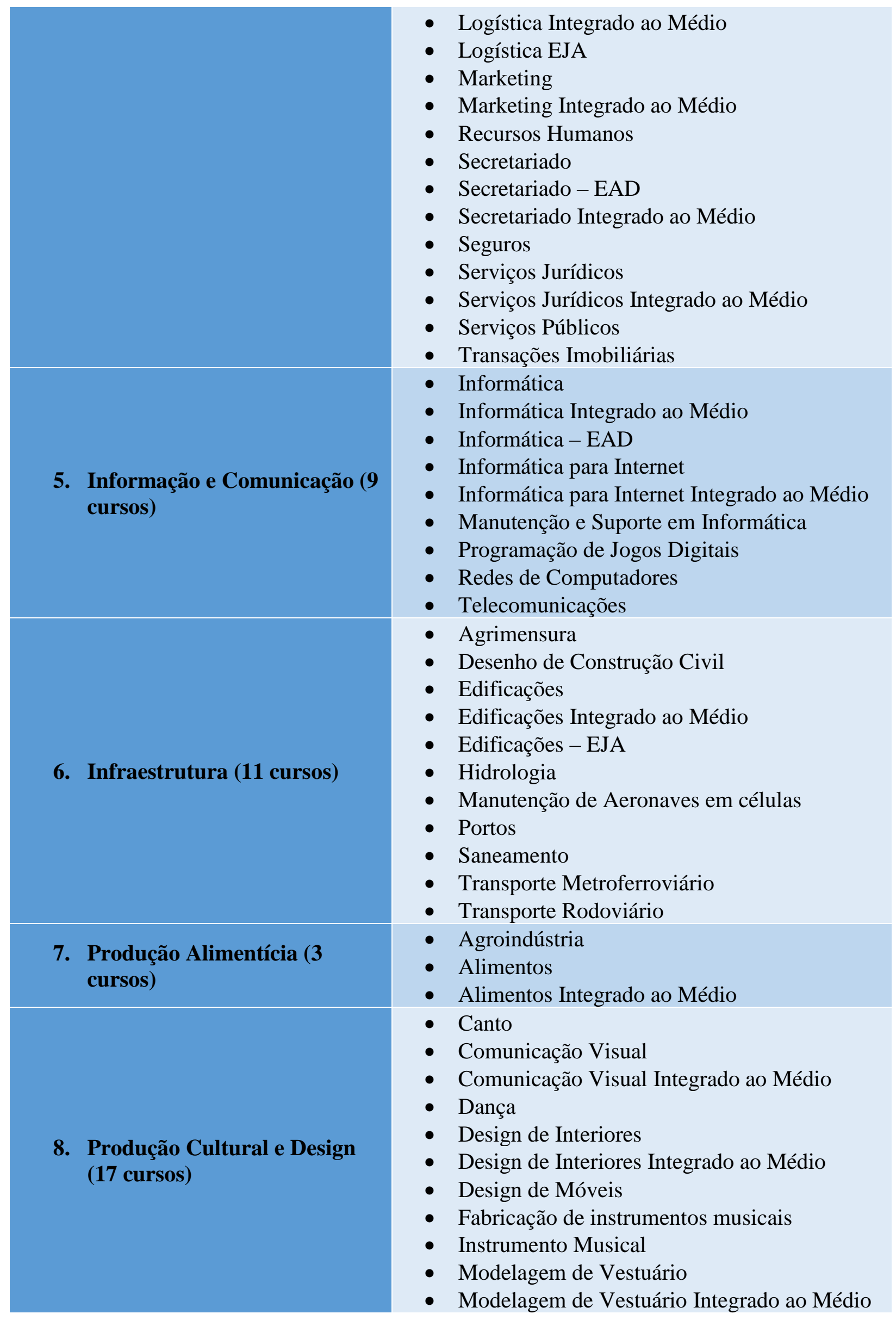




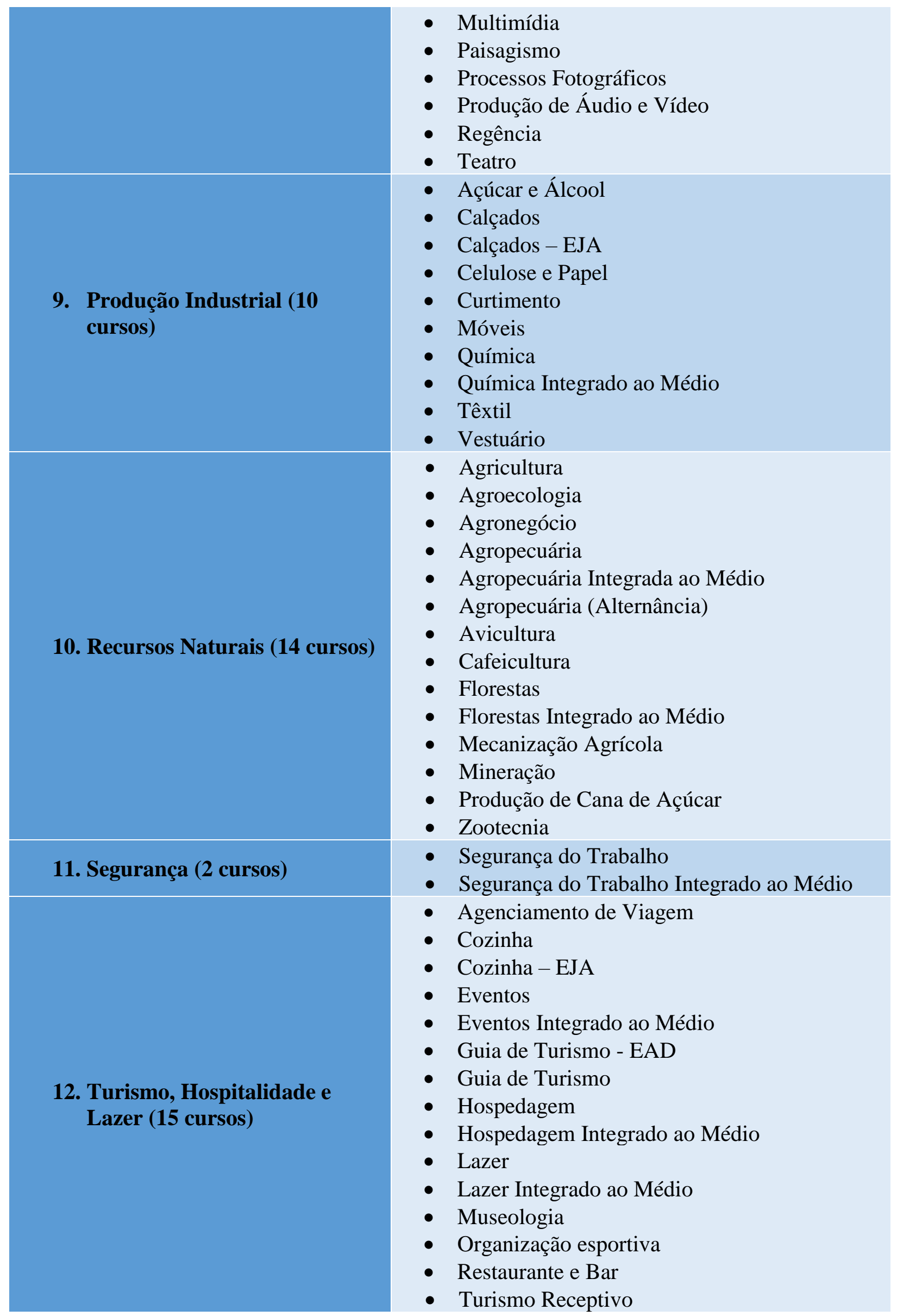


APÊNDICE B - Questionário 
O objetivo deste questionário é investigar os efeitos das características empreendedoras e do ambiente escolar na Intenção Empreendedora do estudante de nível médio/técnico em Administração. As informações obtidas por intermédio dessa pesquisa serão confidenciais.

1) Idade:

2) Sexo: $\square$ Feminino $\square$ Masculino

3) Qual o nome da sua ETEC?

4) Qual é o curso que está fazendo:

5) Assinale as atividades que você exerce ou exerceu antes de ingressar na ETEC. Pode assinalar mais de uma opção.

$\square$ Grupo Religioso

$\square$ Movimento Escoteiro

$\square$ Trabalho Voluntário

Movimento Estudantil (Grêmio)

Trabalho em empresa familiar (ajudar os pais em um negócio familiar)

$\square$ Trabalho em empresa de terceiros (CLT, estagiário, jovem aprendiz, dentre outros)

$\square$ Criação de conteúdo online (Blog, Vlog, "Youtuber" e criação de aplicativos)

Outros

6) Considerando-se seus parentes (avós, pai, mãe, tios e/ou irmãos) algum deles possui negócio próprio?

$\square$ Não tenho parentes de primeiro grau com negócio próprio.

$\square$ Sim, meu pai.

$\square$ Sim, minha mãe.

Sim, meu pai e minha mãe.

Sim, outro (s) parente(s) (avós, tios e/ou irmãos).

7) Em relação a sua MÃE, quando você apresentava ideias sobre o que estudar e em relação aos seus planos futuros, qual era a postura que ela assumia?

$\square$ Ela nunca apoia minhas ideias.

$\square$ Ela raramente apoia minhas ideias.

$\square$ Ela apoia de vez em quando.

$\square$ Ela apoia frequentemente minhas ideias.

Ela sempre apoia e incentivou minhas ideias. 
8) O fracasso nos negócios de parentes ou conhecidos aumentou o seu interesse em empreender?

$\square$ Não conheci fracassos nos negócios de parentes e conhecidos.

$\square$ O fracasso nos negócios de parentes e conhecidos estimulou meu interesse em empreender.

$\square$ O fracasso nos negócios de parentes e conhecidos limitou meu interesse em empreender.

$\square$ O fracasso nos negócios de parentes e conhecidos não influenciou meu interesse em empreender.

$\square$ O fracasso nos negócios de parentes e conhecidos apenas reforçou minha restrição em empreender.

9) O acesso a casos positivos de negócios aumentou o seu interesse em empreender?

$\square$ Não tive acesso a casos positivos de negócios.

$\square$ Os casos positivos de negócios reforçaram meu interesse em empreender.

$\square$ Os casos positivos de negócios limitaram meu interesse em empreender.

$\square$ Os casos positivos de negócios não interferiram meu interesse em empreender.

$\square$ Os casos positivos de negócios reforçaram minha restrição em empreender.

Em relação às afirmações a seguir, selecione a opção de sua preferência:

\begin{tabular}{|c|c|c|c|c|}
\hline 1 & 2 & 3 & 4 & 5 \\
$\begin{array}{c}\text { Discordo } \\
\text { Plenamente }\end{array}$ & Discordo & Indiferente & Concordo & $\begin{array}{c}\text { Concordo } \\
\text { Plenamente }\end{array}$ \\
\hline
\end{tabular}

\begin{tabular}{|c|c|c|c|c|c|c|}
\hline 10) & $\begin{array}{l}\text { Frequentemente, sou escolhido como líder em atividades escolares ou } \\
\text { em outros grupos que eu venha a participar. }\end{array}$ & 1 & 2 & 3 & 4 & 5 \\
\hline 11) & As pessoas respeitam a minha opinião. & 1 & 2 & 3 & 4 & 5 \\
\hline 12) & $\begin{array}{l}\text { Eu posso convencer as pessoas a superar conflitos e trabalhar em } \\
\text { equipe para alcançar um resultado particular. }\end{array}$ & 1 & 2 & 3 & 4 & 5 \\
\hline 13) & $\begin{array}{l}\text { Eu sou capaz de encorajar as pessoas a executar tarefas para as quais } \\
\text { são desmotivadas. }\end{array}$ & 1 & 2 & 3 & 4 & 5 \\
\hline 14) & Eu sempre planejo muito bem tudo o que faço. & 1 & 2 & 3 & 4 & 5 \\
\hline 15) & $\begin{array}{l}\text { Quando tenho um objetivo, procuro definir onde quero chegar e } \\
\text { detalho todos os passos que devo seguir. }\end{array}$ & 1 & 2 & 3 & 4 & 5 \\
\hline 16) & $\begin{array}{l}\text { Sei que posso definir meus planos para o futuro de curto, médio e longo } \\
\text { prazos. }\end{array}$ & 1 & 2 & 3 & 4 & 5 \\
\hline 17) & Eu gosto de estabelecer metas para me sentir desafiado. & 1 & 2 & 3 & 4 & 5 \\
\hline 18) & Prefiro um trabalho cheio de novidades a uma atividade rotineira. & 1 & 2 & 3 & 4 & 5 \\
\hline 19) & Eu gosto de mudar minha maneira de trabalhar sempre que possível. & 1 & 2 & 3 & 4 & 5 \\
\hline 20) & $\begin{array}{l}\text { Eu gosto de melhorar o modo convencional e correto de fazer } \\
\text { atividades, não seguindo rigorosamente as etapas. }\end{array}$ & 1 & 2 & 3 & 4 & 5 \\
\hline 21) & Aposto na criatividade ao elaborar projetos / atividades. & 1 & 2 & 3 & 4 & 5 \\
\hline 22) & $\begin{array}{l}\text { Eu assumiria uma dívida de longo prazo, acreditando nas vantagens } \\
\text { que uma oportunidade de negócio me traria. }\end{array}$ & 1 & 2 & 3 & 4 & 5 \\
\hline 23) & Aceito correr riscos em troca de possíveis benefícios. & 1 & 2 & 3 & 4 & 5 \\
\hline
\end{tabular}




\begin{tabular}{|c|c|c|c|c|c|c|}
\hline 24) & $\begin{array}{l}\text { Ao tomar decisões procuro me arriscar mais ao invés de ficar na minha } \\
\text { zona de conforto. }\end{array}$ & 1 & 2 & 3 & 4 & 5 \\
\hline 25) & $\begin{array}{l}\text { credito que se eu estiver disposto a correr mais riscos, isso poderá } \\
\text { e trazer resultados mais interessantes. }\end{array}$ & 1 & 2 & 3 & 4 & 5 \\
\hline 26) & $\begin{array}{l}\text { s contatos sociais que tenho são muito importantes para minha vida } \\
\text { essoal. }\end{array}$ & 1 & 2 & 3 & 4 & 5 \\
\hline 27) & Conheço várias pessoas que poderiam me ajudar profissionalmente. & 1 & 2 & 3 & 4 & 5 \\
\hline 28) & me relaciono muito facilmente com outras pessoas. & 1 & 2 & 3 & 4 & 5 \\
\hline 29) & rocuro manter contato constante com pessoas da minha rede. & 1 & 2 & 3 & 4 & 5 \\
\hline 30) & $\begin{array}{l}\text { nto que estou pronto para poder montar o meu próprio negócio no } \\
\text { turo. }\end{array}$ & 1 & 2 & 3 & 4 & 5 \\
\hline 31) & $\begin{array}{l}\text { esmo que eu venha trabalhar para outras empresas, nunca } \\
\text { andonarei meu sonho de abrir meu negócio. }\end{array}$ & 1 & 2 & 3 & 4 & 5 \\
\hline 32) & Iinha maior conquista será ter meu próprio negócio. & 1 & 2 & 3 & 4 & 5 \\
\hline 33) & anter meu próprio negócio. & 1 & 2 & 3 & 4 & 5 \\
\hline 34) & enho a intenção de abrir meu próprio negócio no futuro. & 1 & 2 & 3 & 4 & 5 \\
\hline 35) & $\begin{array}{l}\text { eio que tenho habilidade em identificar boas oportunidades no } \\
\text { ibiente no qual estou inserido. }\end{array}$ & 1 & 2 & 3 & 4 & 5 \\
\hline 36) & $\begin{array}{l}\text { omparando com as outras pessoas que convivem comigo, creio que } \\
\text { u uma pessoa muito mais persistente que as demais. }\end{array}$ & 1 & 2 & 3 & & 5 \\
\hline 37) & $\begin{array}{l}\text { u sempre encontro soluções criativas aos problemas em que me } \\
\text { eparo. }\end{array}$ & 1 & 2 & 3 & 4 & 5 \\
\hline 38) & $\begin{array}{l}\text { executo minhas tarefas corretamente, respeitando os prazos } \\
\text { tabelecidos. }\end{array}$ & 1 & 2 & 3 & 4 & 5 \\
\hline 39) & $\begin{array}{l}\text { sso trabalhar de forma produtiva sob estresse contínuo, pressão e } \\
\text { nflito. }\end{array}$ & 1 & 2 & 3 & 4 & 5 \\
\hline 40) & $\begin{array}{l}\text { posso desenvolver e manter relações favoráveis com potenciais } \\
\text { vestidores. }\end{array}$ & 1 & 2 & 3 & 4 & 5 \\
\hline 41) & $\begin{array}{l}\text { sso ver novas oportunidades de mercado, introduzindo novos } \\
\text { odutos e serviços. }\end{array}$ & 1 & 2 & 3 & 4 & 5 \\
\hline 42) & Tenho condições de recrutar e treinar pessoas. & 1 & 2 & 3 & 4 & 5 \\
\hline 43) & $\begin{array}{l}\text { sso desenvolver um ambiente de trabalho que incentive as pessoas } \\
\text { xperimentar algo novo. }\end{array}$ & 1 & 2 & 3 & 4 & 5 \\
\hline 44) & O ambiente escolar me ajudou a detectar oportunidades de negócio. & 1 & 2 & 3 & 4 & 5 \\
\hline 45) & O ambiente escolar me auxiliou a ser persistente. & 1 & 2 & 3 & 4 & 5 \\
\hline 46) & $\begin{array}{l}\text { ambiente escolar me motivou a querer abrir meu próprio negócio no } \\
\text { uturo. }\end{array}$ & 1 & 2 & 3 & 4 & 5 \\
\hline 47) & O ambiente escolar melhorou minha habilidade de liderança. & 1 & 2 & 3 & 4 & 5 \\
\hline 48) & O ambiente escolar colaborou para minha capacidade de inovar. & 1 & 2 & 3 & 4 & 5 \\
\hline 49) & O ambiente escolar contribuiu para minha capacidade de planejar. & 1 & 2 & 3 & 4 & 5 \\
\hline 50) & O ambiente escolar favoreceu minha criatividade. & 1 & 2 & 3 & 4 & 5 \\
\hline 51) & $\begin{array}{l}\mathrm{O} \text { ambiente escolar me ensinou a tomar decisões quando enfrento um } \\
\text { problema, aprimorando minha habilidade de assumir riscos calculados }\end{array}$ & 1 & 2 & 3 & 4 & 5 \\
\hline
\end{tabular}


52) As atividades em feiras (FETEPS), eventos e workshops me proporcionaram diversos contatos importantes pessoal e profissionalmente. 
APÊNDICE C - A Educação Profissional no Brasil 
Nessa seção será comentada a história da educação profissional no Brasil se restringindo apenas aos marcos históricos que a compõe, o intuito é de elencar como esse ensino foi tratado ao longo dos anos. O quadro 7, traz em síntese como a educação profissional no Brasil aconteceu mediante ao regime político vivenciado e para melhor contextualização, será dividido em 3 partes.

Quadro 7 - Trajetória do Ensino Profissional no Brasil

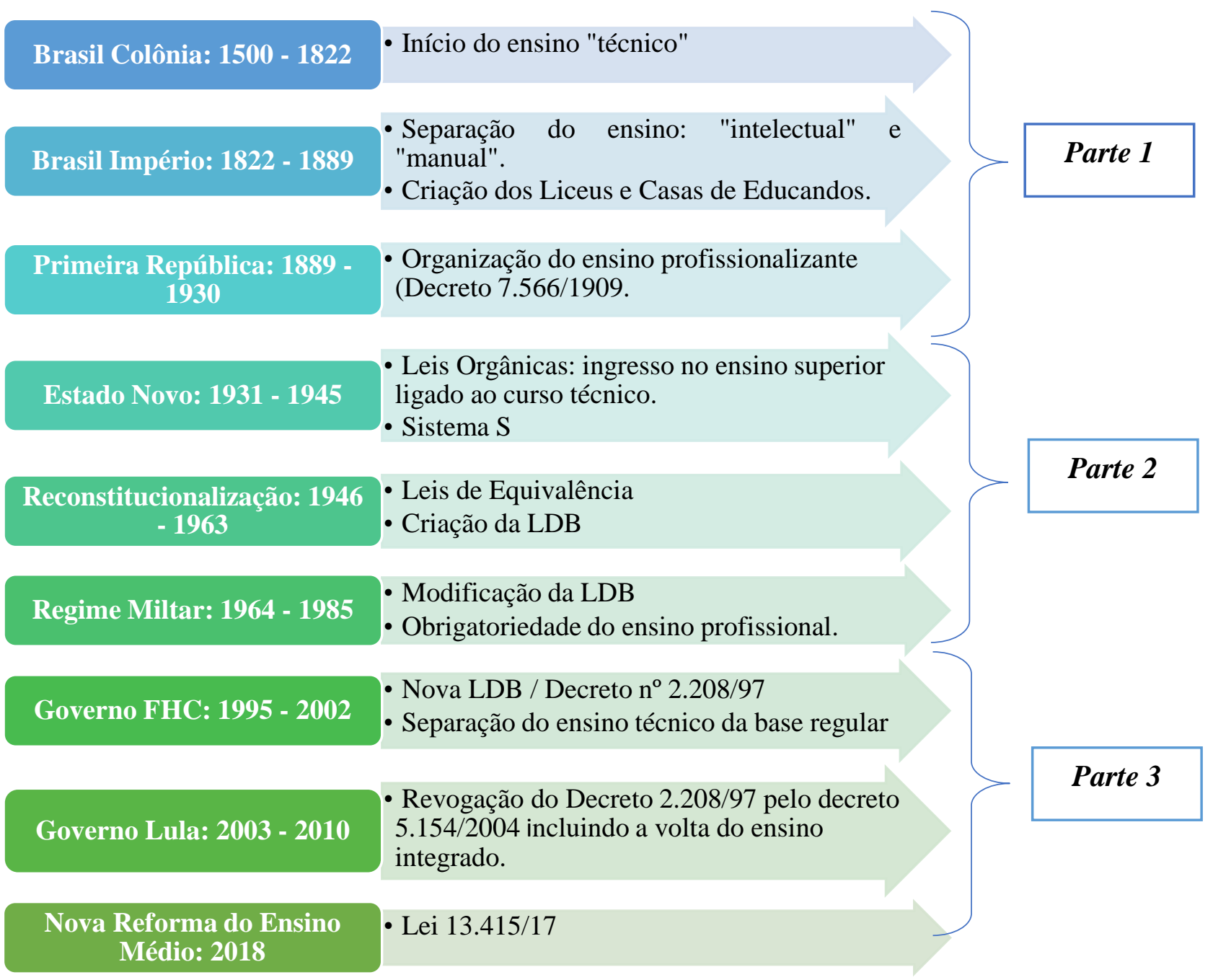

Fonte: Autora

Parte 1: Brasil Colônia a Primeira República

Os primeiros registros sobre a educação profissional no Brasil se dão nos tempos da colonização, nesse período o sistema econômico era baseado na agropecuária e em atividades de exploração da terra. O sistema de aprendizagem era o sistema europeu no qual o aprendiz era sempre uma criança ou um adolescente, o ofício era ensinado tanto para escravos como para 
homens livres. Porém os ofícios voltados a aspectos intelectuais eram para os setores da elite, os serviços manuais como representavam esforço físico, eram destinados aos escravos. (CARVALHO, 2011; MANFREDI, 2002).

Por muito tempo, depois de séculos de história, houve essa percepção por parte do mercado de trabalho, em que os serviços que requerem esforço físico e manual são os que não precisam de tanta instrução e isso se deu diante de um contexto histórico iniciado a mais de 500 anos e perpetuado a longos séculos na história da nossa educação.

A próxima fase do período da educação profissional se deu quando o Brasil virou império. Neste momento surge as casas de educandos artífices e os liceus de artes e ofícios. O primeiro foi criado pelo Estado na intenção de oferecer ensino para órfãos e abandonados, envolvia o trabalho e aprendizagem compulsória de caráter assistencialista, ensinavam carpintaria, sapataria e alfaiataria, já os liceus por sua vez eram estabelecimentos mantidos por benfeitores e nobres da época, o ensino era voltado para arquitetura civil, desenho de máquinas e arte cerâmica (CARVALHO, 2011; MANFREDI, 2002).

Com a transição do período imperial para a primeira república o Brasil sofreu transformações, principalmente porque neste período aconteceu a abolição da escravatura e o projeto de imigração. Outro fator importante foi a expansão da economia cafeeira, com isso o Brasil começou o processo de industrialização (mesmo que ainda bem incipiente) e de infraestrutura (ferroviária e urbana) (MANFREDI, 2002).

Com essas novas áreas, houve grande necessidade de mudança na qualificação profissional, as escolas que se dedicavam ao ensino de ofícios artesanais e manufatureiro, agora cedem lugar a rede de escolas incentivadas pelo governo federal e neste momento ainda mais pelo governo estadual que agora tinha autonomia para organizar o ensino profissionalizante devido ao decreto 7.566 de 23 de setembro de 1909 que instituía uma legislação própria para as escolas de ensino profissionalizante com uma estrutura própria, metodologia, currículo, alunos e condição de ingresso, se diferenciando do ensino elementar. O público alvo não era mais os 'desafortunados', mas sim uma nova classe que estava se formando de trabalhadores livres e assalariados dos setores urbanos. (MANFREDI, 2002).

\section{Parte 2: Estado Novo a Regime Militar}

No período do Estado Novo a economia é voltada a industrialização, incentivado pelo governo mediante a pesados investimentos na criação de parques industriais, nesse novo 
modelo além de provocar mudanças na estrutura do Estado, fez com que novas estratégias fossem realizadas para a capacitação da mão de obra (CARVALHO, 2011; MANFREDI, 2002).

Em 1942, pela criação das Leis Orgânicas foram redefinidos os currículos e as articulações entre os cursos, ramos, ciclos e graus. O ensino médio era para jovens a partir dos 12 anos e era dividido em duas partes: primeiro ciclo e segundo ciclo, ambos com 5 divisões, porém 4 delas era voltada para formar uma força de trabalho específica, começam nessa fase a serem chamadas de cursos técnicos e o outro curso restante é voltado para o ingresso ao nível superior. Quem fazia os cursos técnicos também podiam ingressar no ensino superior, porém teriam que ser na área na qual correspondia a sua trajetória no ensino médio. Nessa mesma época nasce o sistema $S$ uma rede de escolas voltada a educação profissional paraestatal, composto por instituições privadas mantidas com recursos públicos, relativos aos percentuais de contribuições compulsórias dos trabalhadores de cada setor e gerenciada pelos órgãos sindicais (confederações e federações) de representação empresarial. (CARVALHO, 2011; MANFREDI, 2002).

$\mathrm{Na}$ fase da reconstitucionalização, com as leis de equivalência (Lei 1076/1950 e 1821/1953) teve o início a paridade entre todos os ciclos do ensino médio para efeito de antecedente para o ingresso do estudante para o próximo nível escolar, com a Lei de Diretrizes e Bases da Educação Nacional (LDB 4024/1961) esse processo ganhou mais ênfase e força para quebrar essa dualidade educacional. $O$ processo para ingresso ao ensino superior dos concluintes do ensino técnico foi extinta, desde que fossem aprovados em exames que abrangiam as disciplinas não cursadas no $2^{\circ}$ ciclo do secundário (CUNHA, 2000; MANFREDI, 2002).

Porém na fase do Regime Militar parte da LDB com a Lei 5692/1971 foi modificada, estabelecendo novamente a obrigatoriedade da habilitação profissional no nível secundário. Essa lei instituiu um novo ensino de $1^{\circ}$ grau (fundamental) obrigatório para todos, agora com 8 anos de duração, o ensino médio com 4 anos era dividido em duas partes, a primeira com finalidade ao ingresso a universidade e outra para o trabalho. $\mathrm{O} 2^{\circ}$ grau com finalidade profissionalizante e compulsória, nesse momento tinha função de conter a demanda de candidatos para o ensino superior, pois seu objetivo era encaminhá-los para o mercado de trabalho supostamente carente de profissionais (CUNHA, 2000; MANFREDI, 2002).

Parte 3: Governo FHC e Nova Reforma do Ensino Médio 
O governo de Fernando Henrique Cardoso se deparou logo no início com o projeto da nova Lei de Diretrizes Básicas para Educação que estava em processo de discussão desde antes da promulgação da Constituição de 1988. O projeto previa a separação do ensino técnico da educação básica regular, colocando o ensino profissional como alternativa à educação básica. (CARVALHO, 2011; CUNHA, 2000; MANFREDI, 2002).

A Nova LDB constituída pelo decreto 2.208/97 teve como finalidade a regulamentação dos artigos 39 a 42 afirmando alguns objetivos da Educação Profissional como: (a) formar técnicos de nível médio para os diferentes setores da economia; (b) especializar e aperfeiçoar o trabalhador em conhecimentos tecnológicos, e; (c) qualificar, requalificar e treinar jovens e adultos com qualquer nível de escolaridade, para sua inserção e melhor desempenho no exercício do trabalho (CARVALHO, 2011; CUNHA, 2000; MANFREDI, 2002).

A desvinculação, entre o ensino médio e o ensino técnico deu a oportunidade aos jovens que se tivessem efetivo interesse na profissionalização para emprego imediato, procurasse o ensino técnico, não obrigando a todos a realização do mesmo (CARVALHO, 2011; CUNHA, 2000; MANFREDI, 2002).

Logo após as diretrizes curriculares para o ensino médio serem publicadas, as da educação profissional de nível técnico foram formadas pela resolução da Câmara de Educação Básica do Conselho Nacional da Educação - CEB/CNE 4/99 -, que determinou que a educação profissional fosse organizado por áreas profissionais, ou também conhecidas por eixos tecnológicos, cada uma delas com suas caracterizações gerais e carga horária mínima para cada habilitação, as primeiras áreas profissionais constituídas eram 20 em seu início, hoje são 13 eixos tecnológicos vigentes (CUNHA, 2000).

O CPS trabalha hoje com cursos que comtemplam os 13 eixos tecnológicos estabelecidos em suas unidades, são mais de 120 cursos como será evidenciado no próximo ponto desse trabalho.

No período de transição entre os governos Fernando Henrique Cardoso e Luís Inácio Lula da Silva retoma-se a discussão sobre a relação entre o ensino médio e o ensino técnico, essas discussões culminou no decreto 5.154/2004 revogando o Decreto ${ }^{\circ}$ 2.208/97, que deixou flexível a articulação do ensino médio com o ensino técnico, mantendo as duas possibilidades já existentes (as formas subsequente e concomitante) e incluindo a possibilidade do ensino integrado entre o ensino médio e a educação profissional incluindo a possibilidade do ensino integrado entre o ensino médio e a educação profissional (CUNHA, 2000; MOURA, 2010).

As formas já existentes foram mantidas, mais principalmente porque a forma sequencial era muitas vezes procurada por aqueles que além de não ter condições de acessar o ensino 
superior, também tinham dificuldades em conseguir se inserir no mercado de trabalho por ter cursado um ensino médio de baixa qualidade que não deu base para a ocupação procurada e a forma concomitante (CARVALHO, 2011; MOURA, 2010).

O CPS sempre esteve atualizado com as reformas do ensino profissional técnico, tanto no processo de separação do Ensino Técnico com o Ensino Médio e no processo concomitante e sequencial no governo de Fernando Henrique Cardoso, como no retorno da modalidade do ensino médio integrado ao técnico, realizado no governo de Luiz Inácio Lula da Silva, e hoje oferece todas essas modalidades como será apresentado no ponto a seguir.

Uma nova reforma está tramitando nos dias atuais, desde 2015 esse tema está nos holofotes de todo país, a lei 13.415/2017 irá mudar algumas questões que rege a LDB referente a Base Nacional Comum Curricular (BNCC). A BNCC é o documento que define o conjunto de aprendizagens essenciais que todos os estudantes devem desenvolver ao longo das fases da Educação Básica (ensino infantil, fundamental e médio) (COSTA; COUTINHO, 2018; MECMINISTÉRIO DA EDUCAÇÃO, 2017).

Conforme o art. 36, o currículo do ensino médio será composto pela Base Nacional Comum Curricular (BNCC) e por itinerários formativos, que deverão ser organizados por meio da oferta de diferentes arranjos curriculares, conforme a relevância para o contexto local e a possibilidade dos sistemas de ensino, a saber: I - linguagens e suas tecnologias; II - matemática e suas tecnologias; III - ciências da natureza e suas tecnologias; IV - ciências humanas e sociais aplicadas; V - formação técnica profissional (BRASIL, 2017).

Diante disso a educação técnica e profissional na nova mudança, poderá ser organizada em módulos e as escolas poderão ofertar essa modalidade diante as especificidades e arranjos locais, caso a escola não consiga ofertar essa modalidade por questões de estrutura ou formação pedagógica dos professores ela poderá realizar parcerias e convênios com instituições de ensino que ofertem formação técnica e profissional de modo presencial e a distância reconhecidas, de modo que as competências e os cursos desenvolvidos em outros espaços sejam validados (BRASIL, 2017; FERRETI; SILVA, 2017).

Ainda existe muita discussão sobre essa alteração que está prevista para 2019 e ainda não se sabe ao certo como se dará essa realização. O objetivo desse ponto na dissertação é tratar da trajetória do ensino técnico ao longo da história do Brasil e considerou pertinente tratar desse aspecto para melhor compreensão do momento recente sobre o ensino médio/técnico.

O CPS ainda está em discussão quanto ao assunto, foi lançado nesse ano um documento de proposta para adequação do seu currículo a Lei 13.415/2017. Esse documento tem como base os parâmetros Curriculares Nacionais do Ensino Médio e será usado como referência para 
a construção dos currículos do Ensino Médio com a integração do itinerário da formação técnica e profissional e apoiará também a construção das demais opções de Ensino Médio, com ênfase nos itinerários pertinentes a áreas do conhecimento, no entanto ainda não se sabe ao certo como será aplicada essas propostas para o ano de 2019.

Em resumo: é possível identificar como a educação técnica está intimamente ligada ao contexto histórico, político e econômico de cada fase. Cada governo estruturou a educação técnica mediante as necessidades econômicas as quais o país estava passando, isso só demonstra o tamanho e a importância desse ensino e agora com a Lei 13.415/2017 a inclusão desse itinerário formativo dentro das áreas já existentes do currículo veio corroborar a relevância desse estudo. 
ANEXO A - Maps das Etecs 


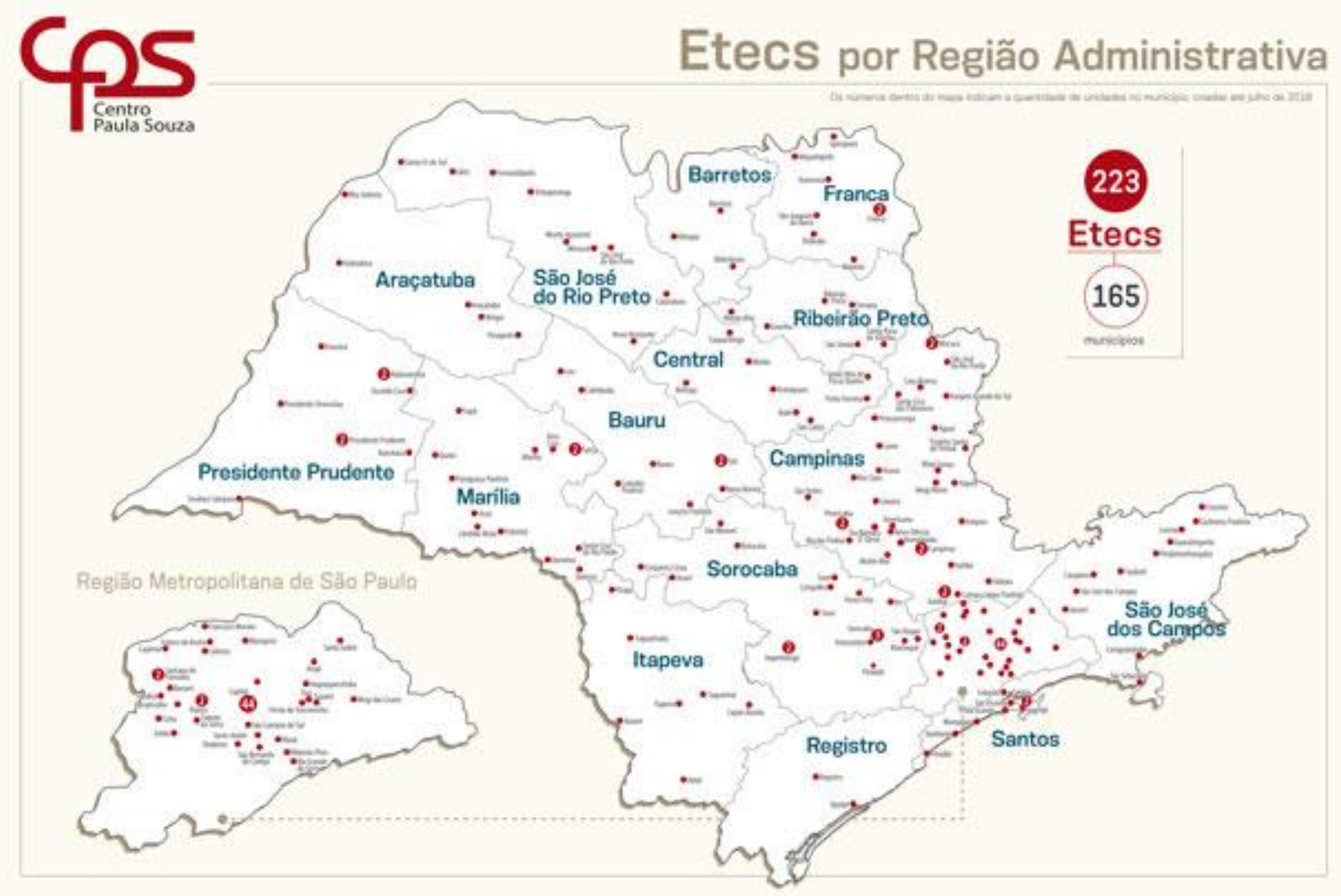

